\title{
Geohydrology of the Stockton Formation and Cross-Contamination Through Open Boreholes, Hatboro Borough and Warminster Township, Pennsylvania
}

By RONALD A. SLOTO, PAOLA MACCHIAROLI, and MICHAEL T. TOWLE

U.S. GEOLOGICAL SURVEY

Water-Resources Investigations Report 96-4047

Prepared in cooperation with the

U.S. ENVIRONMENTAL PROTECTION AGENCY

Lemoyne, Pennsylvania 1996

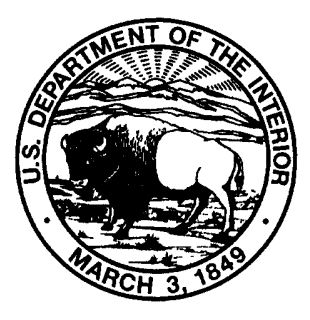




\title{
U.S. DEPARTMENT OF THE INTERIOR
}

BRUCE BABBITT, Secretary

\author{
U.S. GEOLOGICAL SURVEY
}

Gordon P. Eaton, Director

The use of firm, trade, and brand names in this report is for identification purposes only and does not constitute endorsement by the U.S. Geological Survey.

For additional information write to:

\section{District Chief}

U.S. Geological Survey

840 Market Street

Lemoyne, PA 17043-1586
Copies of this report can be purchased from:

U.S. Geological Survey

Branch of Information Services

Box 25286

Denver, CO 80225-0286 


\section{CONTENTS}

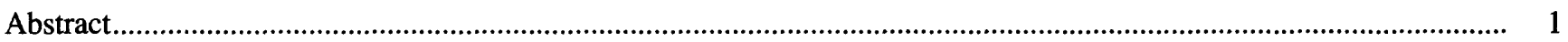

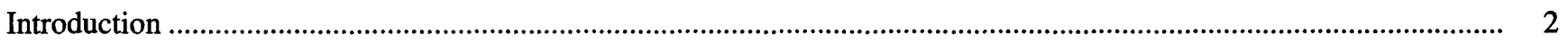

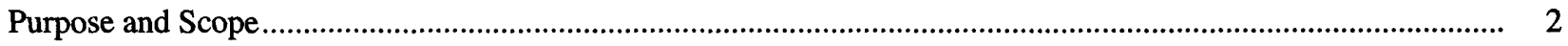

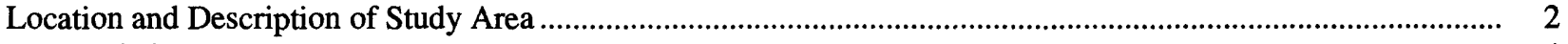

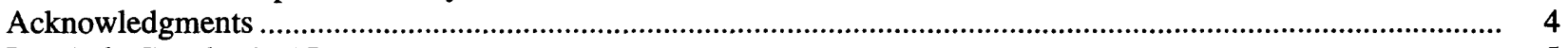

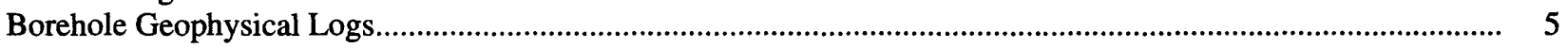

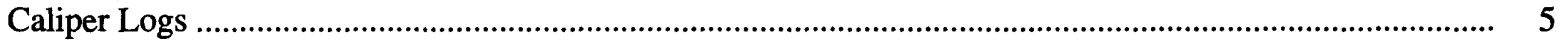

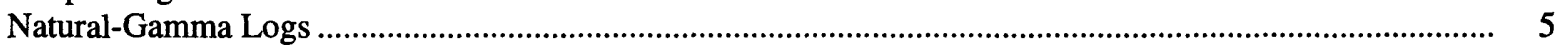

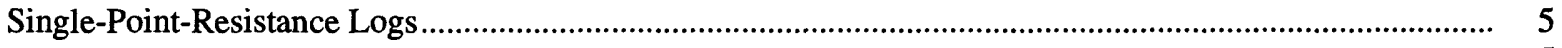

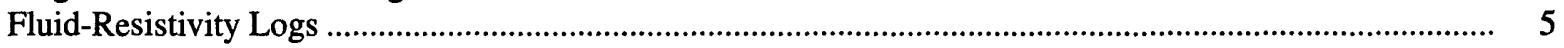

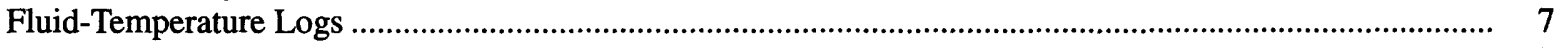

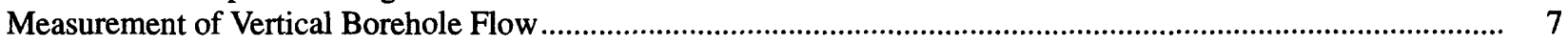

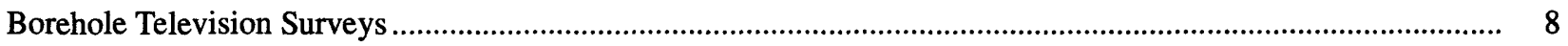

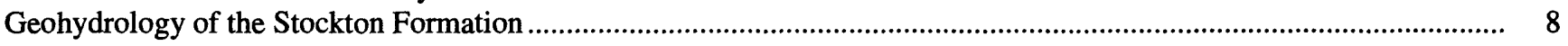

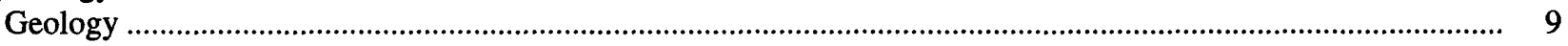

Correlation of Lithostratigraphic Units Identified in Rock Cores to Geophysical Logs .......................... 10

Hydrology......

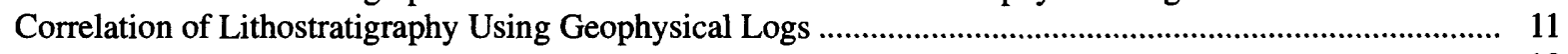

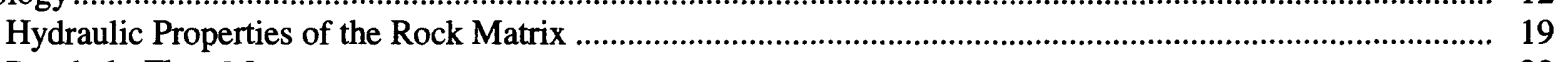

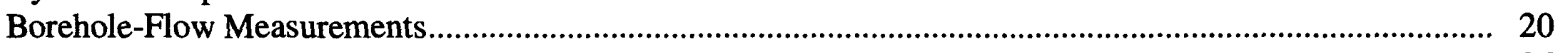

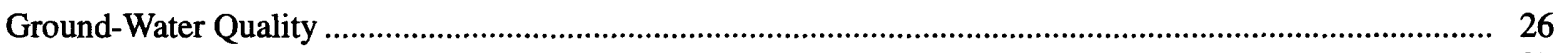

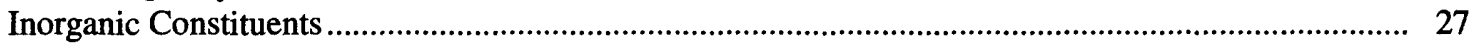

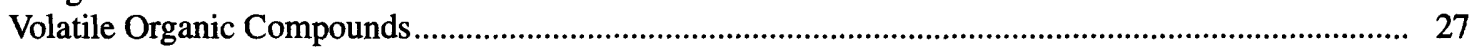

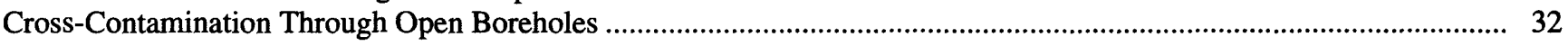

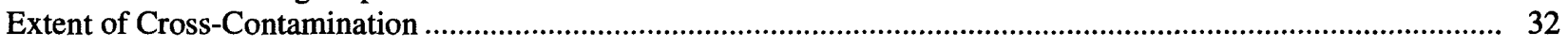

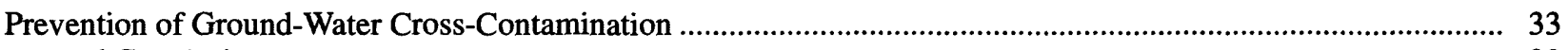

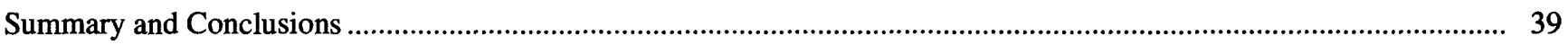

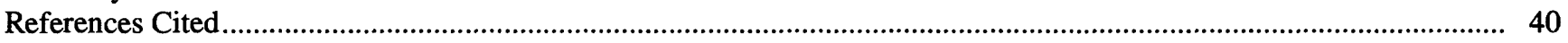

\section{PLATES}

[Plates are in pocket]

1. Interpreted geologic section approximately along strike, Hatboro Borough, Pennsylvania

2. Interpreted geologic section approximately along dip, Hatboro Borough, Pennsylvania

\section{FIGURES}

1. Map showing location of study area

2. Map showing location of National Priorities List (superfund) sites in Hatboro Borough and Warminster

Township, Pennsylvania

3. Caliper, natural-gamma, single-point-resistance, fluid-temperature, and fluid-resistivity logs from borehole BK-2512, Warminster Township, Pennsylvania .

4. Photograph from borehole television survey of borehole BK-2512, Warminster Township, Pennsylvania, showing fracture at 246 feet below land surface

5. Graph showing movement of a high-conductance fluid slug injected 120 feet below land surface in borehole BK-2512, Warminster Township, Pennsylvania

6. Caliper log showing borehole-flow measurements made in borehole BK-2512, Warminster Township, Pennsylvania

7. Caliper, natural-gamma, and single-point-resistance logs from borehole BK-1845, Warwick Township, Pennsylvania

8. Natural-gamma logs from well BK-2584, Warminster Township, Pennsylvania, before and after construction as a monitor well 
9. Photograph from borehole television survey of borehole BK-2530, Warminster Township, Pennsylvania, showing a horizontal fracture within a sandstone bed at 78.2 feet below land surface

10. Photograph from borehole television survey of borehole BK-2536, Warminster Township, Pennsylvania, showing a horizontal fracture at the contact between a sandstone bed (upper bed) and a siltstone bed (lower bed) at 141.9 feet below land surface

11. Photograph from borehole television survey of borehole BK-2597, Warminster Township, Pennsylvania, showing a nearly vertical fracture at 168.5 feet below land surface.

12. Caliper log from borehole BK-2597, Warminster Township, Pennsylvania, showing borehole-flow measurement

13. Caliper, natural-gamma, and generalized lithologic logs; screened intervals; borehole-flow measurements; and water levels for the MG-1222 monitor well cluster, Hatboro Borough, Pennsylvania

14. Hydrographs from the MG-1222 monitor well cluster, Hatboro Borough, Pennsylvania, September 4 to October 3, 1991

15. Graph showing porosity of the rock matrix determined from outcrop samples and rock-core thin sections

16. Caliper, fluid-temperature, and fluid-resistivity logs from borehole MG-1236, Hatboro Borough,

Pennsylvania, showing borehole-flow measurements.

7. Caliper, fluid-temperature, and fluid-resistivity logs from borehole BK-2600, Warminster Township, Pennsylvania, showing borehole-flow measurements.

. Caliper, fluid-temperature, and fluid-resistivity logs from borehole BK-1845, Warwick Township, Pennsylvania, showing borehole-flow measurements.

Caliper, fluid-temperature, and fluid-resistivity logs from borehole BK-949, Warminster Township, Pennsylvania, showing borehole-flow measurements

20. Caliper log from borehole BK-2794, Warminster Township, Pennsylvania, showing borehole-flow measurements made with a heat-pulse flowmeter

21. Piper diagram of cation-anion percentages for pumping-well, shallow borehole-flow, and deep borehole-flow water samples, Hatboro Borough and Warminster Township, Pennsylvania

Diagram showing typical reaction pathways for the anaerobic degradation of tetrachloroethylene and trichloroethylene by reductive dehalogenation

Map showing location of boreholes and wells sampled for chemical analysis and selected boreholes and wells in which geophysical logs were run, Hatboro Borough and Warminster Township, Pennsylvania

24. Map showing boreholes sampled for volatile organic compounds in the Jacksonville Road area, Hatboro Borough, Pennsylvania.

25. Caliper, fluid-temperature, and fluid-resistivity logs from borehole MG-1114, Hatboro Borough, Pennsylvania, showing borehole-flow measurements.

26. Caliper, fluid-temperature, and fluid-resistivity logs from borehole MG-1222, Hatboro Borough, Pennsylvania, showing borehole-flow measurements.

27. Caliper, natural-gamma, and generalized lithologic logs from boreholes BK-2792, BK-2793, and BK-2794, Warminster Township, Pennsylvania.....

\section{TABLES}

1. Porosity estimated from thin sections of rock cores from boreholes MG-1223 and MG-1283, Hatboro Borough, Pennsylvania

2. Hydraulic conductivity determined in the laboratory from rock cores from boreholes MG-1223 and

MG-1283, Hatboro Borough, Pennsylvania

3. Volatile organic compounds detected in ground water, Hatbono Borough and Warminster Township, Pennsylvania.

4. Volatile organic compounds detected in borehole-flow samples from nine sampled boreholes in the Jacksonville Road area, Hatboro Borough, Pennsylvania ...

5. Estimated quantity of volatile organic compounds moving downward in the Stockton Formation through nine sampled boreholes in the Jacksonville Road area, Hatboro Borough, Pennsylvania.

6. Record of wells

7. Results of field determinations

8. Results of chemical analyses for inorganic constituents

9. Results of chemical analysis for volatile organic compounds 
CONVERSION FACTORS, VERTICAL DATUM, AND ABBREVIATED WATER-QUALITY UNITS

\begin{tabular}{|c|c|c|}
\hline Multiply & By & To obtain \\
\hline & Length & \\
\hline inch (in.) & 25.4 & millimeter \\
\hline foot $(\mathrm{ft})$ & 0.3048 & meter \\
\hline mile (mi) & 1.609 & kilometer \\
\hline \multirow[t]{2}{*}{ foot per minute $(\mathrm{ft} / \mathrm{min})$} & 0.3048 & meter per minute \\
\hline & Area & \\
\hline \multirow[t]{2}{*}{ square mile $\left(\mathrm{mi}^{2}\right)$} & 2.590 & square kilometer \\
\hline & Volume & \\
\hline \multirow[t]{2}{*}{ gallon (gal) } & 3.785 & liter \\
\hline & Flow & \\
\hline gallon per minute (gal $/ \mathrm{min}$ ) & 0.06308 & liter per second \\
\hline gallon per year (gal/yr) & 3.785 & liter per year \\
\hline
\end{tabular}

Sea level: In this report, "sea level" refers to the National Geodetic Vertical Datum of 1929—a geodetic datum derived from a general adjustment of the first-order level nets of both the United States and Canada, formerly called Sea Level Datum of 1929.

Abbreviated water-quality units used in report:

micrograms per liter $(\mu \mathrm{g} / \mathrm{L})$

milligrams per liter $(\mathrm{mg} / \mathrm{L})$ 


\title{
Geohydrology of the Stockton Formation and Cross-Contamination Through Open Boreholes, Hatboro Borough and Warminster Township, Pennsylvania
}

\author{
By Ronald A. Sloto, Paola Macchiaroli, and Michael T. Towle
}

\section{Abstract}

The study area consists of a 9-square-mile area underlain by sedimentary rocks of the middle arkose member of the Stockton Formation of Upper Triassic age. In the Hatboro area, the Stockton Formation strikes approximately N. $65^{\circ}$ E. and dips approximately $9^{\circ} \mathrm{NW}$. The rocks are chiefly arkosic sandstone and siltstone. Rocks of the Stockton Formation form a complex, heterogeneous, multiaquifer system consisting of a series of gently dipping lithologic units with different hydraulic properties. Most ground water in the unweathered zone moves through a network of interconnecting secondary openings-fractures, bedding planes, and joints. Ground water is unconfined in the shallower part of the aquifer and semiconfined or confined in the deeper part of the aquifer. Nearly all deep wells in the Stockton Formation are open to several water-bearing zones and are multiaquifer wells. Each water-bearing zone usually has a different hydraulic head. Where differences in hydraulic head exist between water-bearing zones, water in the well bore flows under nonpumping conditions in the direction of decreasing head.

Determination of the potential for borehole flow was based on caliper, natural-gamma, singlepoint-resistance, fluid-resistivity, and (or) fluidtemperature logs that were run in 162 boreholes 31 to 655 feet deep. The direction and rate of borehole-fluid movement were determined in 83 boreholes by the brine-tracing method and in 10 boreholes by use of a heat-pulse flowmeter.
Borehole flow was measurable in 65 of the 93 boreholes ( 70 percent). Fluid movement at rates up to 17 gallons per minute was measured. Downward flow was measured in 36 boreholes, and upward flow was measured in 23 boreholes, not including those boreholes in which two directions of flow were measured. Both upward and downward vertical flow was measured in six boreholes; these boreholes are 396 to 470 feet deep and were among the deepest boreholes logged. Fluid movement was upward in the upper part of the borehole and downward in the lower part of the borehole in two boreholes. Fluid movement was downward in the upper part of the borehole and upward in the lower part of the borehole in three boreholes.

Ground-water contamination by volatile organic compounds (VOC's) is widespread in the study area. Detectable concentrations of VOC's were present in water samples from all 24 wells sampled in Hatboro Borough and in water samples from 10 of 14 wells ( 71 percent) sampled in Warminster Township. Samples of borehole flow from nine boreholes in the industrial area of Hatboro were collected for laboratory analysis to estimate the quantity of VOC's in borehole flow. Downward flow was measured in all of these boreholes. Concentrations of TCE, TCA, and 1,1-DCE as great as 5,800,1,400, and 260 micrograms per liter, respectively, show that some water moving downward in the aquifer through these open boreholes is highly contaminated and that open boreholes may contribute 
substantially to ground-water contamination. An estimated 14.7 gallons per year of VOC's were moving downward through the nine open boreholes sampled from the contaminated, upper part of the aquifer to the lower part, which is tapped by public supply wells.

Borehole geophysical logs were used as a guide to design and construct monitor-well networks at three National Priorities List sites in the area. An open borehole was drilled, and a suite of geophysical logs was run. Interpretation of geophysical logs enabled the identification of water-bearing zones that produce and receive water; these are zones that should not be connected. From the logs, discrete intervals to be monitored were selected. In the Stockton Formation, the same water-bearing zone may not be intersected in adjacent boreholes, especially if it is a vertical fracture with a different magnetic orientation than that of the adjacent boreholes. In most areas of the Stockton Formation, depth of water-bearing zones in an area cannot be determined from one borehole. Each borehole should be logged and evaluated separately.

\section{INTRODUCTION}

Many public supply and industrial wells in the United States are completed as open boreholes that obtain water from several formations or from several water-bearing zones in a single formation. The advantage of this construction practice is that a much greater yield can be obtained than if a well is open to a single formation or water-bearing zone. Unfortunately, these boreholes, which connect several aquifers or waterbearing zones, commonly short-circuit the groundwater-flow system and act as conduits for the transport of contaminants.

Hatboro Borough and Warminster Township are underlain by a bedrock-aquifer system in the Triassic age Stockton Formation. The residents of Hatboro Borough and Warminster Township depend on ground water withdrawn from the Stockton Formation for their drinking-water supply. The Stockton Formation is one of the most important aquifers in southeastern Pennsylvania and provides the water supply for more than one million residents.

\section{Purpose and Scope}

This report presents the results of a study done by the U.S. Geological Survey (USGS) in cooperation with the U.S. Environmental Protection Agency (USEPA) to identify and assess crosscontamination by multiaquifer boreholes in the Stockton Formation. The study used a combination of borehole geophysical methods, measurement of vertical borehole flow, and sampling and analysis of borehole fluid to assess aquifer cross-contamination in the Stockton Formation in Hatboro Borough and Warminster Township in southeastern Pennsylvania.

The purpose of this report is to (1) describe the hydrogeology of the Stockton Formation, (2) quantify the amount and quality of borehole flow in multiaquifer wells, (3) estimate the quantity of volatile organic compounds (VOC's) in borehole flow, and (4) describe how borehole geophysical methods can be used properly to design and construct monitor wells that correct and (or) prevent cross-contamination problems.

The results of this study have wide application to other multiaquifer systems in southeastern Pennsylvania and the Nation. Similar crossconnections between water-bearing zones by wells in other aquifers in the Newark Basin were noted by Sloto and Schreffler (1994).

In this report, the term "borehole" is used to describe open-hole construction drilled holes used for the collection of geologic, hydrologic, and geophysical data. The term "well" is used to describe drilled holes completed as monitor wells, public supply wells, or industrial supply wells.

\section{Location and Description of Study Area}

The study area is a $9-\mathrm{mi}^{2}$ area in Hatboro Borough in Montgomery County and Warminster Township in Bucks County, Pa. (fig. 1), underlain by the Stockton Formation. The study area is centered mainly around an older industrial area typical of many other communities in southeastern Pennsylvania. Much of the industry dates from the World War II or post-World War II eras. In most of these areas, industrial and public supply wells drilled into the Stockton Formation are constructed as open holes with short casings and are open to multiple water-bearing zones. Many of these wells are now abandoned. 


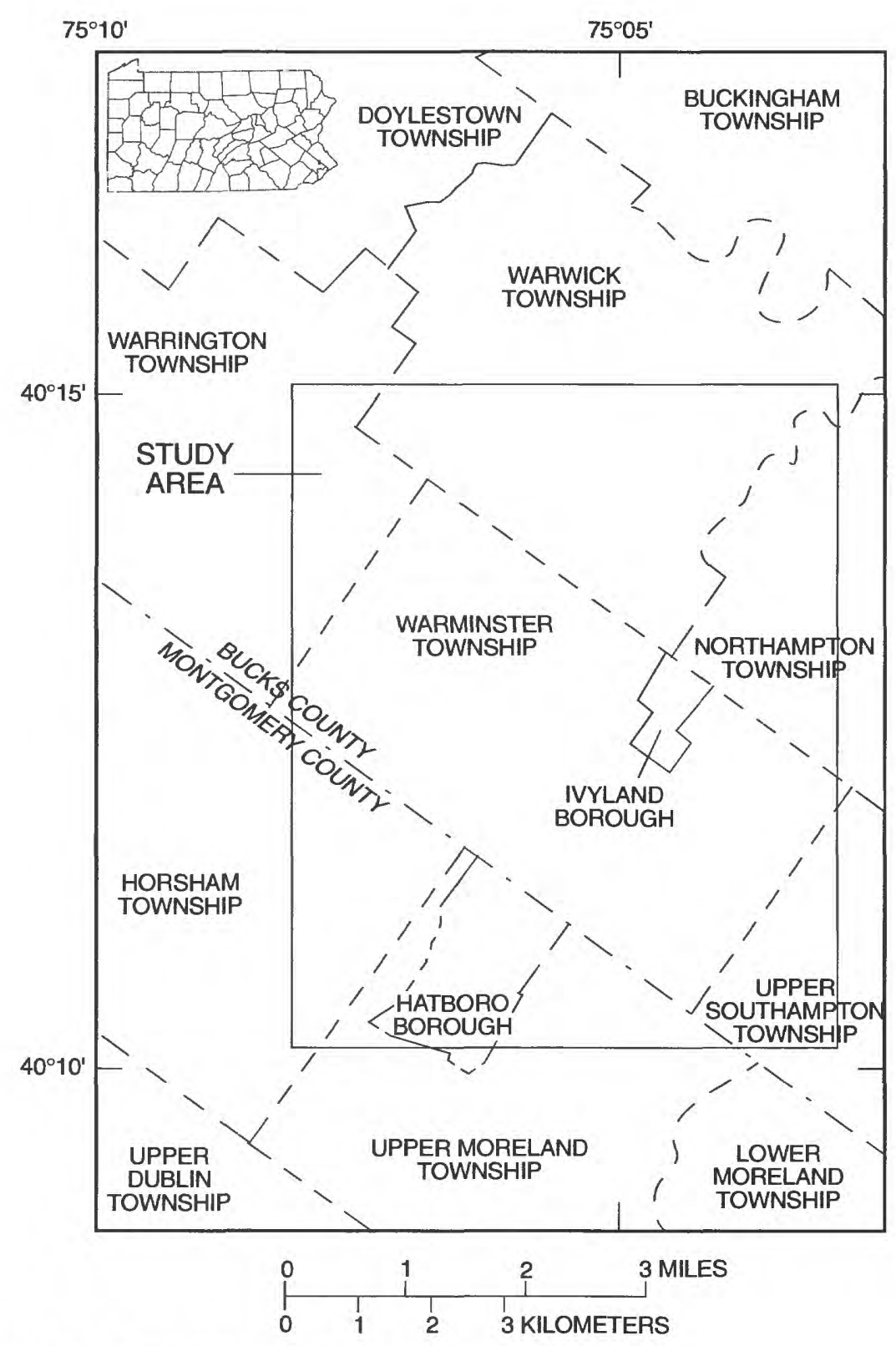

Figure 1. Location of study area.

Ground-water contamination by organic compounds in the Hatboro area has been a problem for many years. A letter dated July 3, 1914, in the files of the Pennsylvania Department of Environmental Protection summarizes the cause of complaints about the water being supplied by the Hatboro Water Company, which operated the borough's water system before it was taken over by Hatboro Borough. One problem noted in the letter was that the drilled supply well was being contaminated by lubricating oil.
The study area includes three sites designated as National Priorities List (NPL) sites, also known as superfund sites, by the USEPA (fig. 2): the Raymark Site, the Fischer and Porter Company Site, and the U.S. Naval Air Warfare Center (NAWC) (U.S. Environmental Protection Agency, 1992).

The Raymark NPL Site in Hatboro has been the location of a metal-fabrication shop since 1948. Solvent containing trichloroethylene (TCE) was used to clean and degrease metal parts. Over several decades of operations, TCE was introduced 


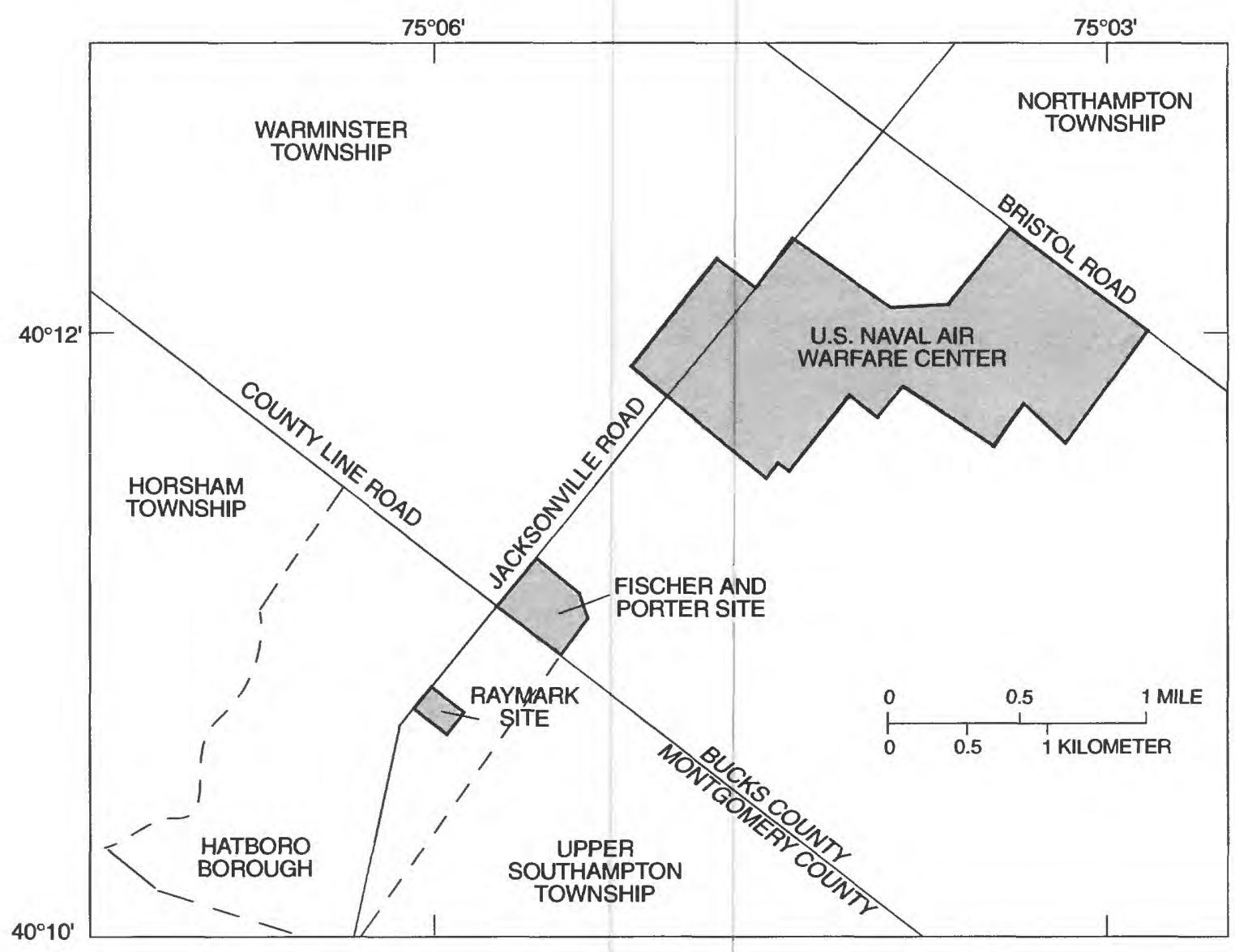

Figure 2. Location of National Priorities List (superfund) sites in Hatboro Borough and Warminster Township, Pennsylvania.

into the environment at the location of a solvent storage tank, a metal degreaser, and four disposal lagoons.

The Fischer and Porter Company NPL Site is a manufacturing facility that produces water-flow and process-control equipment. Solvent containing TCE was used in the manufacturing process and has entered the ground-water system. In 1979, VOC's were detected in nearby public supply wells. VOC's also were detected in Fischer and Porter's onsite supply wells.

The NAWC, formerly the Johnsville Naval Air Development Center, is a U.S. Navy facility commissioned in 1944. Before that, the site was used for manufacturing aircraft. NAWC is used for research, development, testing, and evaluation of naval air-craft systems. NAWC also conducts studies in anti-submarine warfare systems and software development. Wastes were generated at NAWC during aircraft maintenance and repair operations, firefighter training, machine and plating shop operations, spray painting, and research and testing activities. The wastes included solvents, paints, oils, and sludges (Haliburton NUS Environmental Corporation, 1992).

\section{Acknowledgments}

The authors thank the Fischer and Porter Company, Hatboro Authority, HIP Industries, the U.S. Navy, and Warminster Township Municipal Authority for access to their wells for borehole geophysical logging and sampling. Special thanks are due to Robert Todd, Jeff Orient, Kevin Kilmartin, Don Whalen, Lonnie Monaco, Carson Freeman, William Gross, and Michael Hunter for their help. 


\section{Borehole Geophysical Logs}

Borehole geophysical logs used for this study are from (1) boreholes logged for this study, (2) boreholes previously logged by the USGS, and (3) boreholes logged as part of other studies by the USGS for the USEPA at the Raymark and Fischer and Porter Company Sites and for the USEPA and U.S. Navy at the NAWC. Besides boreholes logged during this study, geophysical logs run by the USGS between 1956 and 1990 in the study area were available for 14 boreholes.

Caliper, natural-gamma, single-pointresistance, fluid-resistivity, and (or) fluid-temperature logs were run in 162 boreholes 31 to $655 \mathrm{ft}$ deep to interpret lithostratigraphy, identify water-bearing fractures, and determine possible zones of vertical borehole-fluid movement. A complete suite of geophysical logs from borehole $\mathrm{BK}-2512$ is shown on figure 3 .

\section{Caliper Logs}

Caliper logs provide a continuous record of average borehole diameter, which is related to fractures, lithology, and drilling technique. The caliper tool is calibrated at land surface after each log is run. Caliper logs were used to help correlate lithostratigraphy, identify fractures and possible water-bearing openings, and qualitatively correct other geophysical logs for changes in borehole diameter. Correlation of caliper logs with single-point-resistance, fluidresistance, and fluid-temperature logs was used to identify fractures and water-producing and waterreceiving zones.

The caliper $\log$ (fig. 3) and borehole television survey from borehole BK-2512 show many minor fractures and several major fractures. Major horizontal fractures are at $96,101,148,217$, and $255.5 \mathrm{ft}$ below land surface (bls). Major vertical fractures are at 99-101, 105.5-109, 128-130, 137-142, 144-146, 242-250, and 259-261 ft bls. The large vertical fracture at $242-250 \mathrm{ft}$ bls is the dominant feature in the borehole (fig. 4).

\section{Natural-Gamma Logs}

Natural-gamma logs, also called gamma-ray logs, record the natural-gamma radiation emitted from rocks penetrated by the borehole. Gamma radiation can be measured through casing, but the gamma response is dampened. Uranium-238, thorium-232 and the progeny of their decay series, and potassium- 40 are the most common emitters of natural-gamma radiation. These radioactive elements may be concentrated in clay by adsorption and ion exchange; therefore, fine-grained sedimentary rocks (siltstone units) usually emit more gamma radiation than do coarse-grained sedimentary rocks (sandstone units). Natural-gamma logs were used to differentiate between sandstone and siltstone units and to correlate lithostratigraphy between boreholes.

\section{Single-Point-Resistance Logs}

Single-point-resistance logs record the electrical resistance between the borehole and an electrical ground at land surface. Overall, resistance increases with grain size and decreases with borehole diameter, density of water-bearing fractures, and increasing dissolved-solids concentration of borehole fluid (Keys, 1990). A fluid-filled borehole is required for single-point-resistance logs, and they are run only for the saturated part of the formation below the casing. Single-point-resistance logs were used to correlate lithostratigraphy and sometimes helped to identify the location of water-bearing zones because a fluid-filled fracture is less resistive than solid rock.

\section{Fluid-Resistivity Logs}

Fluid-resistivity logs measure the electrical resistance of fluid in the borehole. Resistivity is the reciprocal of fluid conductivity, and fluid-resistivity logs reflect changes in the dissolved-solids concentration of the borehole fluid. Fluid-resistivity logs were used to identify water-producing and water-receiving zones and to determine intervals of vertical borehole flow. Water-producing and water-receiving zones usually were identified by sharp changes in resistivity, and intervals of borehole flow were identified by a low resistivity gradient between water-producing and water-receiving zones. The fluid-resistivity log from borehole BK-2512 (fig. 3) shows a change in slope at 98, 213, and $252 \mathrm{ft}$ bls. These changes in slope coincide with fractures shown on the caliper log at 217 and $242-250 \mathrm{ft}$ bls. 

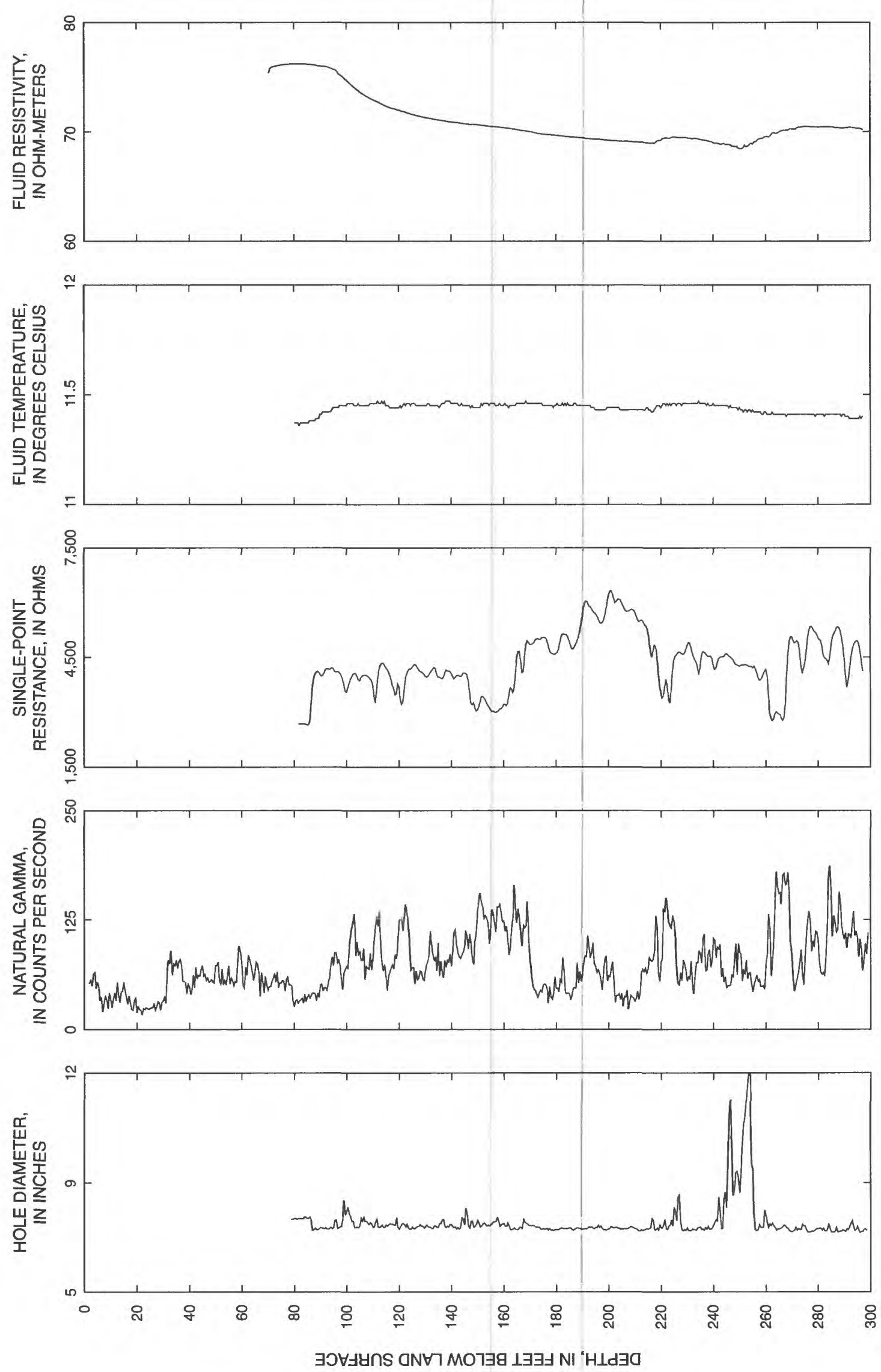

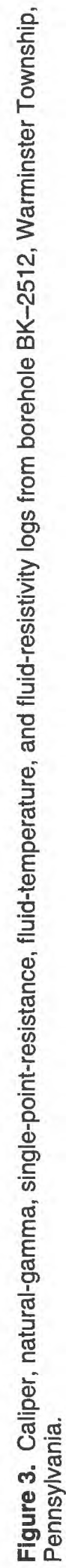




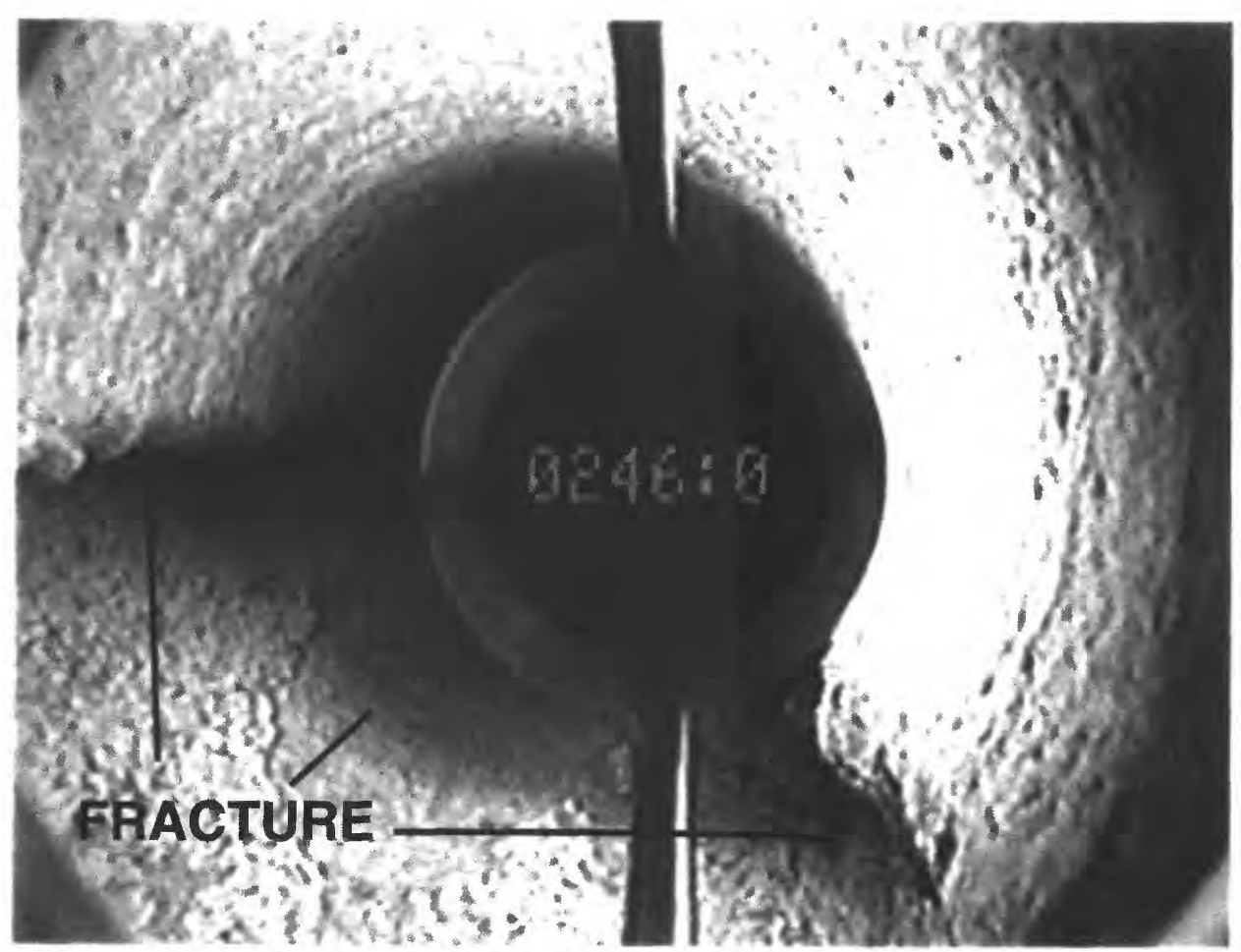

Figure 4. Photograph from borehole television survey of borehole BK-2512, Warminster Township, Pennsylvania, showing fracture at 246 feet below land surface.

\section{Fluid-Temperature Logs}

Fluid-temperature logs provide a continuous record of the temperature of the fluid in the borehole. Temperature logs were used to identify water-producing and water-receiving zones and to determine intervals of vertical borehole flow. Water-producing and water-receiving zones usually were identified by sharp changes in temperature, and intervals of vertical borehole flow were identified by little or no temperature gradient. In the study area, fluid-temperature logs from boreholes with no borehole flow generally show a decrease in fluid temperature with depth caused by surface heating in the upper part of the borehole and an increase in fluid temperature with depth as a function of the geothermal gradient in the lower part of the borehole. The fluidtemperature log from borehole BK-2512 (fig. 3) shows a change in slope at 98 and $252 \mathrm{ft}$ bls and very little gradient between 98 and $252 \mathrm{ft}$ bls, which indicates borehole flow.

\section{Measurement of Vertical Borehole Flow}

Upon completion of geophysical logging, the suite of logs was evaluated in the field to choose zones of potential borehole flow. The direction and rate of borehole-fluid movement were determined in 83 wells by injecting a slug of high-conductance fluid at a specific depth in a borehole and monitoring the movement of the slug with the fluid-resistivity tool. This is the brine-tracing method described by Patten and Bennett (1962). The lower limit of flow measurement is about $0.5 \mathrm{gal} / \mathrm{min}$ in a 6 -in.-diameter borehole. Borehole flow was calculated by

$$
\mathrm{Q}=7.481 \mathrm{~V} \pi \mathrm{r}^{2} \text {, }
$$

where

$\mathrm{Q}$ is borehole flow, in gallons per minute;

$\mathrm{V}$ is the rate of vertical borehole fluid movement, in feet per minute; and

$r$ is the radius of the borehole, in feet. 
The rate and direction of borehole-fluid movement was determined in 10 boreholes by use of a heatpulse flowmeter. A heat-pulse flowmeter operates by slightly heating a small sheet of water between two sensitive thermistors, one below and one above the heating grid. A measurement of direction and flow rate is computed when a peak temperature is recorded by a thermistor. The range of measurable flow is 0.01 to $1.0 \mathrm{gal} / \mathrm{min}$ in a 2- to 10 -in. borehole.

Slugs of high-conductance fluid were injected in borehole BK-2512 at 120, 190, 230, and $270 \mathrm{ft}$ bls. Downward flow at the rate of $1.4 \mathrm{gal} / \mathrm{min}$ was measured at 120 and $190 \mathrm{ft}$ bls. No borehole flow was measurable at 230 or $270 \mathrm{ft}$ bls. The movement of the slug of high-conductance fluid injected at $120 \mathrm{ft}$ bls is shown in figure 5. The slug moved downward at $0.52 \mathrm{ft} / \mathrm{min}$, which is equal to a flow rate of $1.4 \mathrm{gal} / \mathrm{min}$ in an 8 -in.-diameter borehole.

The suite of geophysical logs for borehole BK-2512 (fig. 3) shows that water enters the borehole through a horizontal fracture at $96 \mathrm{ft} \mathrm{bls}$ and moves downward at the rate of $1.4 \mathrm{gal} / \mathrm{min}$ (fig. 6). The borehole television survey shows a disruption of downward particle movement at this fracture. Most of the water is lost to a water-receiving fracture at $217 \mathrm{ft} \mathrm{bls}$; the borehole television survey shows a disruption of downward particle movement at this fracture. The rest of the water is lost to the water-receiving fracture at $242-250 \mathrm{ft}$ bls, which probably receives less than $0.5 \mathrm{gal} / \mathrm{min}$ of water.

\section{Borehole Television Surveys}

Borehole television surveys were conducted in selected boreholes by lowering a waterproof video camera with a wide-angle lens down the borehole and recording the images on videotape. Borehole television surveys were used to aid interpretation of geophysical logs.

\section{GEOHYDROLOGY OF THE STOCKTON FORMATION}

The study area is in the Triassic Lowland Section of the Piedmont Physiographic Province and is underlain by sedimentary rocks of the Stockton Formation of Upper Triassic age. The Stockton Formation is the basal unit of the Newark Supergroup rocks in the Triassic and Jurassic Newark Basin. This basin contains 16,000 to $20,000 \mathrm{ft}$ of nonmarine sedimentary rocks. The Newark Basin is approximately $140 \mathrm{mi}$ long and $32 \mathrm{mi}$ wide and is the largest

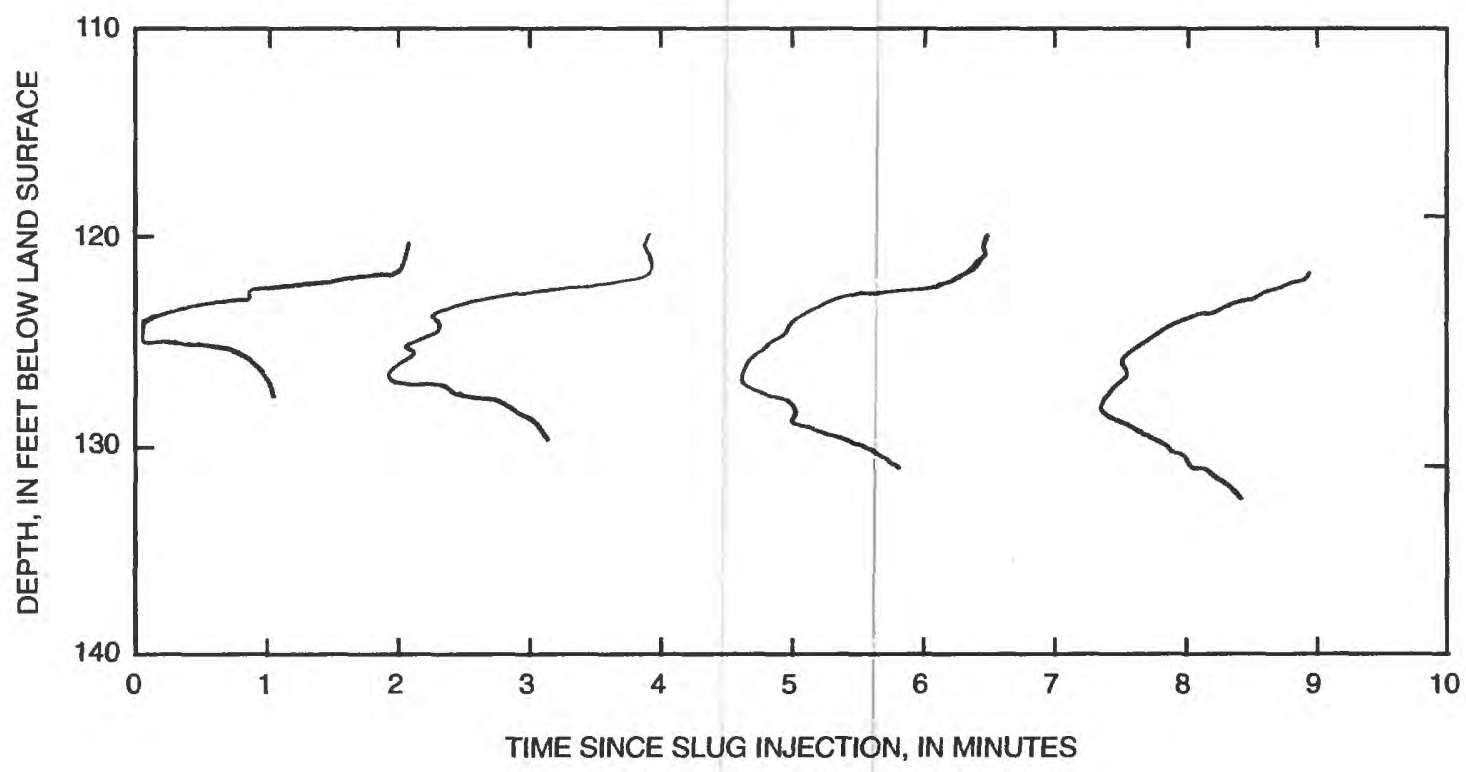

Figure 5. Movement of a high-conductance fluid slug injected 120 feet below land surface in borehole BK-2512, Warminster Township, Pennsylvania. 


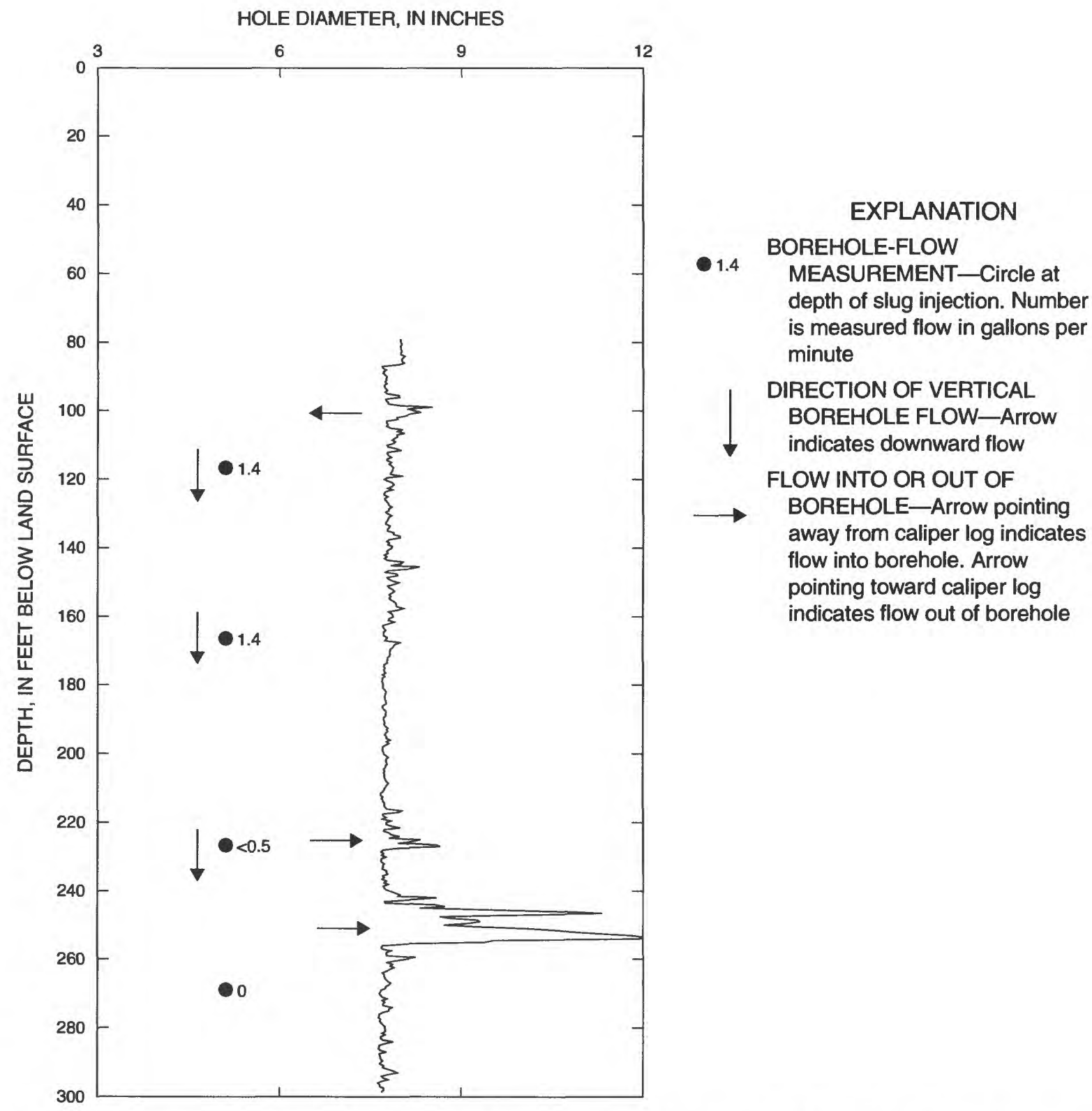

Figure 6. Borehole-flow measurements made in borehole BK-2512, Warminster Township, Pennsylvania.

of the 13 major exposed Triassic-Jurassic rift basins stretching from Nova Scotia to South Carolina. Sedimentation was the result of infilling of a rift basin formed during the initial stages of continental breakup (Turner-Peterson and Smoot, 1985, p. 10). Sedimentation in the Newark Basin began with an influx of arkosic detritus from uplifted crystalline rocks to the south not far from the present-day southern basin margin (Glaeser, 1966, p. 26). One characteristic of the Stockton is the thickbedded to locally massive arkosic sandstones. Sediments were deposited on folded and deeply eroded

Precambrian and Paleozoic rocks. The basin filled with thousands of feet of sediments over a period of about 45 million years.

\section{Geology}

The Stockton Formation was subdivided into three units called the lower arkose, middle arkose, and upper shale members by Rima and 
others (1962). Rocks that underlie the study area belong to the middle arkose member; some deep boreholes may penetrate the lower arkose member. The Stockton Formation is $6,000 \mathrm{ft}$ thick near the Bucks-Montgomery County boundary; the middle arkose member accounts for 70 percent of its thickness. In the Hatboro area, the Stockton Formation strikes approximately N. $65^{\circ}$ E. and dips approximately $9^{\circ} \mathrm{NW}$. (Sloto and others, 1992). The rocks are chiefly arkosic sandstone and siltstone. Quartz and feldspar are the dominant minerals.

The Stockton Formation includes alluvial fans, fluvial and lacustrine sandstones, and fluvial and nearshore lacustrine siltstones (Turner-Peterson and Smoot, 1985). Near its southern margin, the Stockton Formation contains laterally coalescing alluvial fans deposited by well-established streams. Thick, poorly defined, upward fining cycles possibly were deposited by large, perennial, meandering rivers.

\section{Correlation of Lithostratigraphic Units Identified in Rock Cores to Geophysical Logs}

Two continuous rock cores were collected at the Raymark Site (MG-1223 and MG-1283), and three continuous rock cores were collected at the Fischer and Porter Site (BK-2516, BK-2517, and BK-2518). The cores provide a continuous record of site geology and reference points to correlate geophysical logs to lithology. Borehole MG-1223 was cored from the land surface to $200 \mathrm{ft}$ bls; borehole MG-1283 was cored from 190 to $300 \mathrm{ft}$ bls. The two boreholes are $5.8 \mathrm{ft}$ apart. Rock cores from coreholes BK-2516, $\mathrm{BK}-2517$, and BK-2518 extend $262 \mathrm{ft}, 277 \mathrm{ft}$, and $274.5 \mathrm{ft}$ bls, respectively. Eight lithologies were identified from the cores and are listed as follows:

1. Siltstone, reddish-brown or dark purple-gray, can be micaceous.

2. Sandstone, pinkish-gray, silty, fine-grained.

3. Sandstone, dark-gray, very fine-grained.

4. Sandstone, gray, fine-grained.

5. Sandstone, gray, poorly sorted, fine- to mediumgrained.

6. Sandstone, gray, medium-grained.

7. Sandstone, light-gray, medium- to coarse-grained.

8. Conglomerate, light-gray or brown.
Each lithology contains a variable percentage of silt, organic material (lignite), disseminated iron oxides in pore spaces, stylolites, and fractures. Organic material is accompanied by a localized abundance of sulfide minerals. Most fractures are either filled or partly lined with calcite or kaolinite (in the siltstone units). Some fractures are coated with a light green, soapy textured mineral identified by $\mathrm{X}$-ray diffraction analysis as muscovite.

The rock cores show some gradational lithologic units consistent with the fluvial-deltaic depositional environment of the Stockton Formation. A few transitional layers are characterized as a combination of two lithologic units. Transitional layers appear banded or as a random mixture of material from units above and below. Some portions of the rock cores show bedding structures that dip up to $30^{\circ}$ from the horizontal of the core orientation. Stylolites also appear with similar dip angles.

The shale units in the middle arkose member described by Rima and others (1962) were not present in the rock cores and are assumed to have a geophysical response similar to the siltstone units. If a borehole penetrates a shale unit, it would be interpreted as a siltstone unit.

Rock cores were compared with the caliper, natural-gamma, and single-point-resistance logs from each corehole. Variations in natural-gamma and single-point-resistance responses correspond to textural variations. Thin interbeds in each general unit also account for some variation in log response. Overall, siltstone units were identified by an elevated natural-gamma response and a weak single-pointresistance response. Zones of increased borehole diameter (highly fractured zones) shown by the caliper logs correlate with fissile siltstone units; discrete increases in borehole diameter suggest discrete fractures.

Silty, fine-grained sandstone units were identified by an elevated natural-gamma response and commonly parallel variations in natural-gamma and single-point-resistance responses. Very fineand fine-grained sandstone units were identified by a weak natural-gamma and an elevated singlepoint-resistance response. Fine-grained sandstone produced the weakest natural-gamma response of all the lithologic units. Stylolites, which cause a sharp spike on the natural-gamma log because they contain 
gamma-emitting minerals, were observed in the sandstone units of the cores. Because sharp gamma spikes are seen within interpreted sandstone units in logs from other boreholes, stylolites are assumed to be indicators of sandstone.

Poorly sorted, fine- to medium-grained sandstone and medium-grained sandstone units were identified by a weak natural-gamma response and a moderate single-point-resistance response that was less than that of the fine-grained sandstone units. Medium- to coarse-grained sandstone and conglomerate were identified by a weak natural-gamma response and an elevated single-point-resistance response that were weaker than the responses of the fine-grained sandstone units but stronger than the responses of the medium-grained sandstone units.

\section{Correlation of Lithostratigraphy Using Geophysical Logs}

Caliper, natural-gamma, and single-pointresistance logs were used for lithostratigraphic correlation. Lithostratigraphic interpretations and correlations were based on the relative response of the geophysical logs for each borehole and on the comparison of the geophysical logs from each borehole with the geophysical and lithologic logs from coreholes. Driller or geologist logs, where available, helped lithologic interpretations.

Because lithologic units of the Stockton Formation grade, interfinger, and coalesce, none of the units could be used as location indicators (marker beds) within the lithostratigraphic sequence. Therefore, the lithology was first interpreted and subsequently a best fit was made to construct lithostratigraphic models. The accuracy of the correlations deteriorates near the land surface because of the absence of single-point-resistance measurements and dampened natural-gamma response caused by casing and dissolution of gamma-producing elements. Correlations among most of the boreholes are consistent with strike and dip. Correlation of geophysical logs was less certain when the distance between boreholes exceeded $400 \mathrm{ft}$ along strike and $300 \mathrm{ft}$ along dip.

The interpreted lithology of each borehole was extended along strike (N. $65^{\circ}$ E.) or dip $\left(9^{\circ} \mathrm{NW}\right.$.) to the next nearest borehole location to correlate lithostratigraphy. The lithologic units commonly correlated above or below the expected projection line.
This is most likely the manifestation of the lens-like structures characteristic of coalescing alluvial fans. Most units have been interpreted to be continuous, dipping to the northwest with only localized shifts in dip because of thinning of units.

Most geophysical logs are affected by borehole diameter (Keys, 1990, p. 28). The diameter of logged boreholes ranged from 2-in.-diameter coreholes to a 14-in.-diameter abandoned public supply well (MG-212). Because relative log response was used to interpret and correlate lithostratigraphy, the effect of borehole diameter on log response was considered inconsequential.

To evaluate the effect of borehole diameter on geophysical logs, borehole $\mathrm{BK}-1845$ was logged twice, once as a 6-in.-diameter borehole and again after it was reamed to a 10 -in.-diameter borehole. Major fractures are more distinct on the caliper log of the 6-in.-diameter borehole (fig. 7) than on the caliper $\log$ of the 10-in.-diameter borehole, probably because of the reaming. The naturalgamma logs (fig. 7) show higher gamma counts for the 10-in.-diameter borehole than for the 6-in.-diameter borehole, but the pattern of log response is nearly identical. The natural-gamma logs are identical in the lower part of the borehole below $320 \mathrm{ft}$ bls. Single-point-resistance logs show a higher resistance for the 6-in.-diameter borehole than for the 10-in.-diameter borehole, but the pattern of $10 \mathrm{~g}$ response is the same (fig. 7); the decrease in resistance is caused by the increase in borehole diameter.

Natural-gamma logs run in boreholes constructed as monitor wells can be used for stratigraphic correlation, even though the gamma response is dampened. For example, borehole BK-2584 (fig. 8) was logged as a 6-in.-diameter open borehole with $19 \mathrm{ft}$ of 6-in.-diameter steel casing shortly after the completion of drilling. The borehole subsequently was constructed as a monitor well with a PVC screen surrounded by a coarse sand filter pack from 254 to $271 \mathrm{ft}$ bls. From the land surface to $254 \mathrm{ft} \mathrm{bls,} \mathrm{a}$ 2-in.-diameter PVC inner casing was installed, and the annulus between the inner casing and the formation was sealed with a mixture of cement grout and bentonite. Although the response of the naturalgamma log is dampened in the monitor well, the pattern of log response is the same as that of the open borehole (fig. 8). 


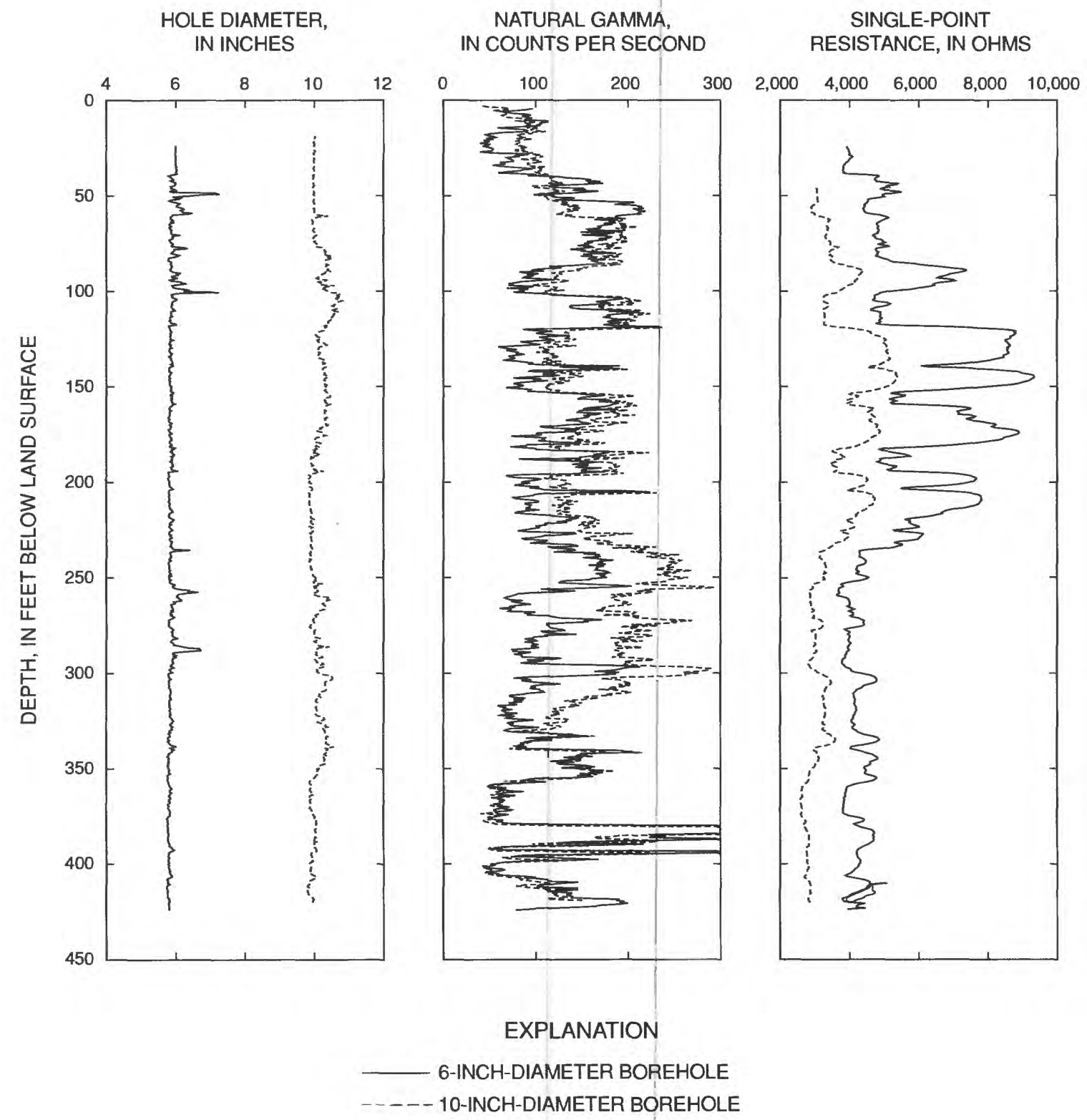

Figure 7. Caliper, natural-gamma, and single-point-resistance logs from borehole BK-1845, Warwick Township, Pennsylvania.

Two lithostratigraphic models were developed for the study area from borehole geophysical logs. A lithostratigraphic model developed for the Fischer and Porter Site was presented by Sloto and others (1996). A lithostratigraphic model for part of Hatboro near the Raymark Site is presented in this report. The interpreted lithostratigraphic correlation of geophysical logs projected to a line approximately along strike is shown on plate 1 , and the interpreted lithostratigraphic correlation of geophysical logs projected to line approximately perpendicular to strike (dip direction) is shown on plate 2. The cross sections show the thinning and thickening of units across the area, which is consistent with the lens-like deposition characteristic of alluvial-fan environments. Cross sections also show the grading and pinching of beds, which is characteristic of the Stockton Formation.

\section{Hydrology}

In the Stockton Formation, ground water in the weathered zone moves through intergranular openings that have formed from weathering. In 

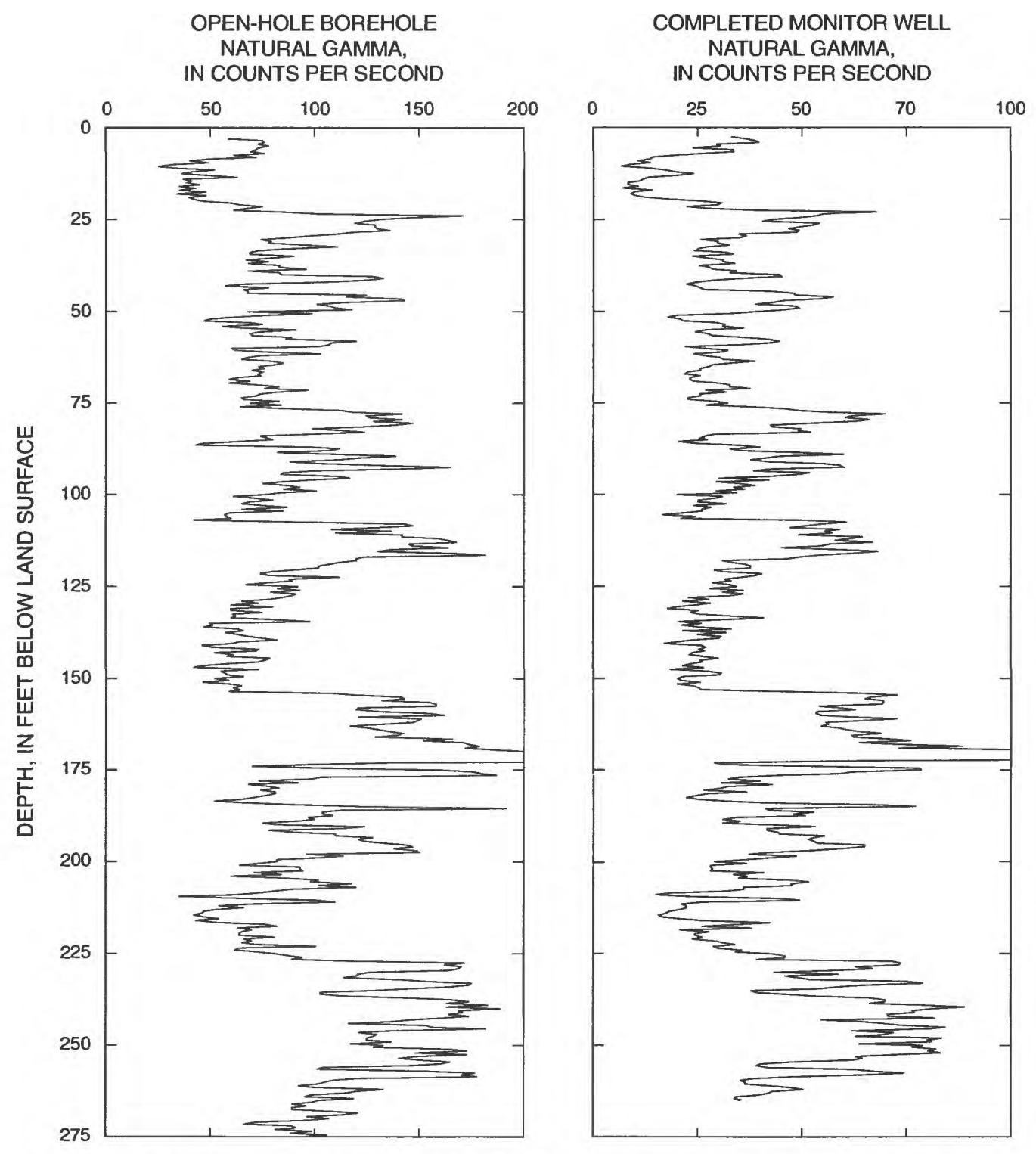

Figure 8. Natural-gamma logs from well BK-2584, Warminster Township, Pennsylvania, before and after construction as a monitor well.

some places, permeability of the weathered zone may be poor because of a high percentage of clay derived from weathering of siltstone. Most ground water in the unweathered zone moves through a network of interconnecting secondary openings - fractures, bedding plane partings, and joints. Horizontal fractures observed in borehole television surveys are aligned with bedding. Some horizontal fractures are within beds, such as the fracture at $78.2 \mathrm{ft}$ bls in borehole BK-2530 (fig. 9), while others are at the contact between beds, such as the fracture at $141.9 \mathrm{ft}$ bls in borehole $\mathrm{BK}-2536$ (fig. 10), which is at the contact between sandstone (upper unit) and siltstone (lower unit).

Steeply dipping or nearly vertical fractures within sandstone units generally produce water. A very large, steeply dipping fracture intersected by borehole BK-2597 at $168.5 \mathrm{ft}$ bls is shown in figure 11 . The borehole intersects this fracture between 162 and $172 \mathrm{ft} \mathrm{bls}$. This fracture produced $10 \mathrm{gal} / \mathrm{min}$ while drilling and produces water that flows upward in the borehole at $6 \mathrm{gal} / \mathrm{min}$ under nonpumping conditions (fig. 12). 


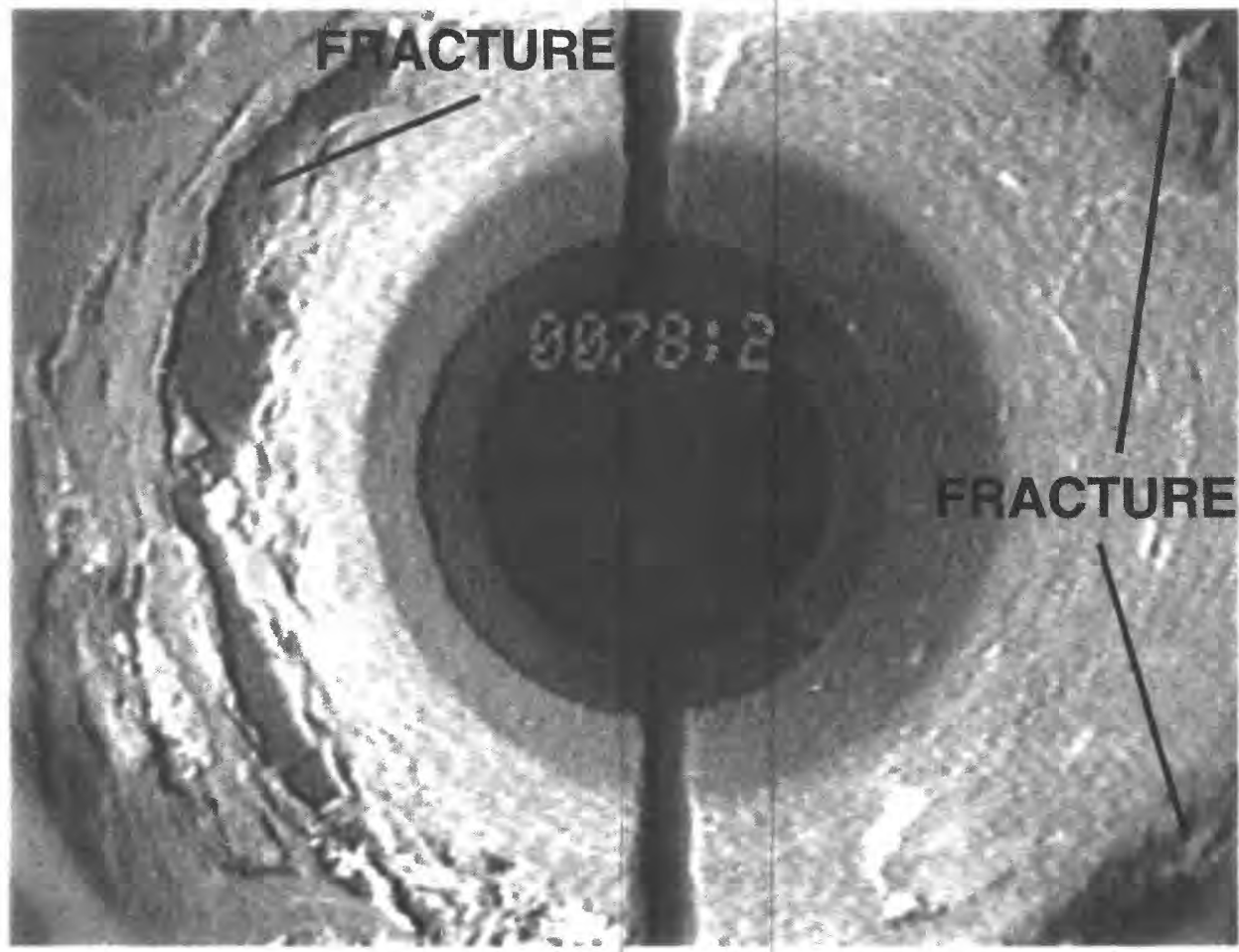

Figure 9. Photograph from borehole television survey of borehole BK-2530, Warminster Township, Pennsylvania, showing a horizontal fracture within a sandstone bed at 78.2 feet below land surface.

Beds within the Stockton Formation are hydraulically connected by vertical joints throughout that cross each other at various angles; therefore, ground water may move across beds, particularly in the direction of dip, rather than through individual beds. Some water-bearing openings may be slightly enlarged by circulating ground water that has weathered and eroded mineral constituents in fractures. Primary porosity that existed before lithification has been almost eliminated by compaction and cementation. Some water may move through intergranular openings in the rock where the cement has been removed and the permeability has increased, but this generally is restricted to only a few sandstone and conglomerate beds.

The rocks of the Stockton Formation form a complex, heterogeneous, multiaquifer system (Sloto and Davis, 1983). This aquifer system consists of a series of gently dipping lithologic units with different hydraulic properties. The ground-water system can be visualizeả as a series of dipping sedimentary beds with a high transmissivity separated by beds with a low transmissivity. The beds, a few inches to a few feet thick, act as a series of alternating aquifers and confining or semiconfining units that form a leaky, multiaquifer system. Each bed generally has different hydraulic properties, and permeability commonly differs from one bed to another. In general, the sandstone units are the principle water-bearing units, but some finer grained units may contain water-bearing zones. However, because of the softness and fine grain size of the siltstone units, water-bearing openings clog. In addition, the soft siltstone beds deform without breaking under stress and, as a result, have lower permeability than the harder sandstone beds, which develop fractures and joints under stress and are more permeable.

Ground water is unconfined in the shallower part of the aquifer system and semiconfined or confined in the deeper part of the aquifer system. Ground water is confined under pressure greater than atmospheric by overlying, less permeable lithologic units. Differences in the ratio of vertical to horizontal hydraulic conductivity and differences in vertical hydraulic conductivity within and among lithologic units create confining conditions. 


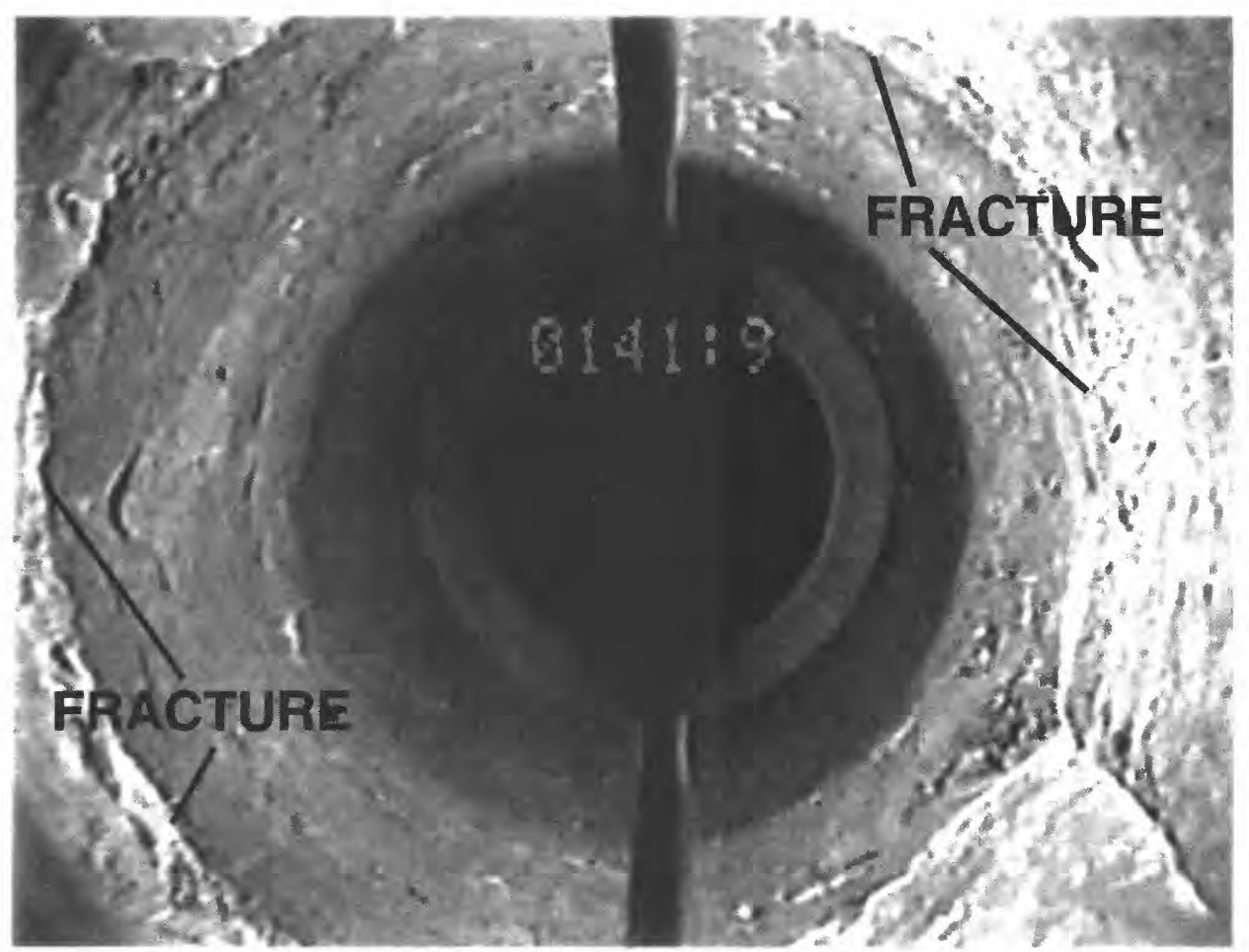

Figure 10. Photograph from borehole television survey of borehole BK-2536, Warminster Township, Pennsylvania, showing a horizontal fracture at the contact between a sandstone bed (upper bed) and a siltstone bed (lower bed) at 141.9 feet below land surface.

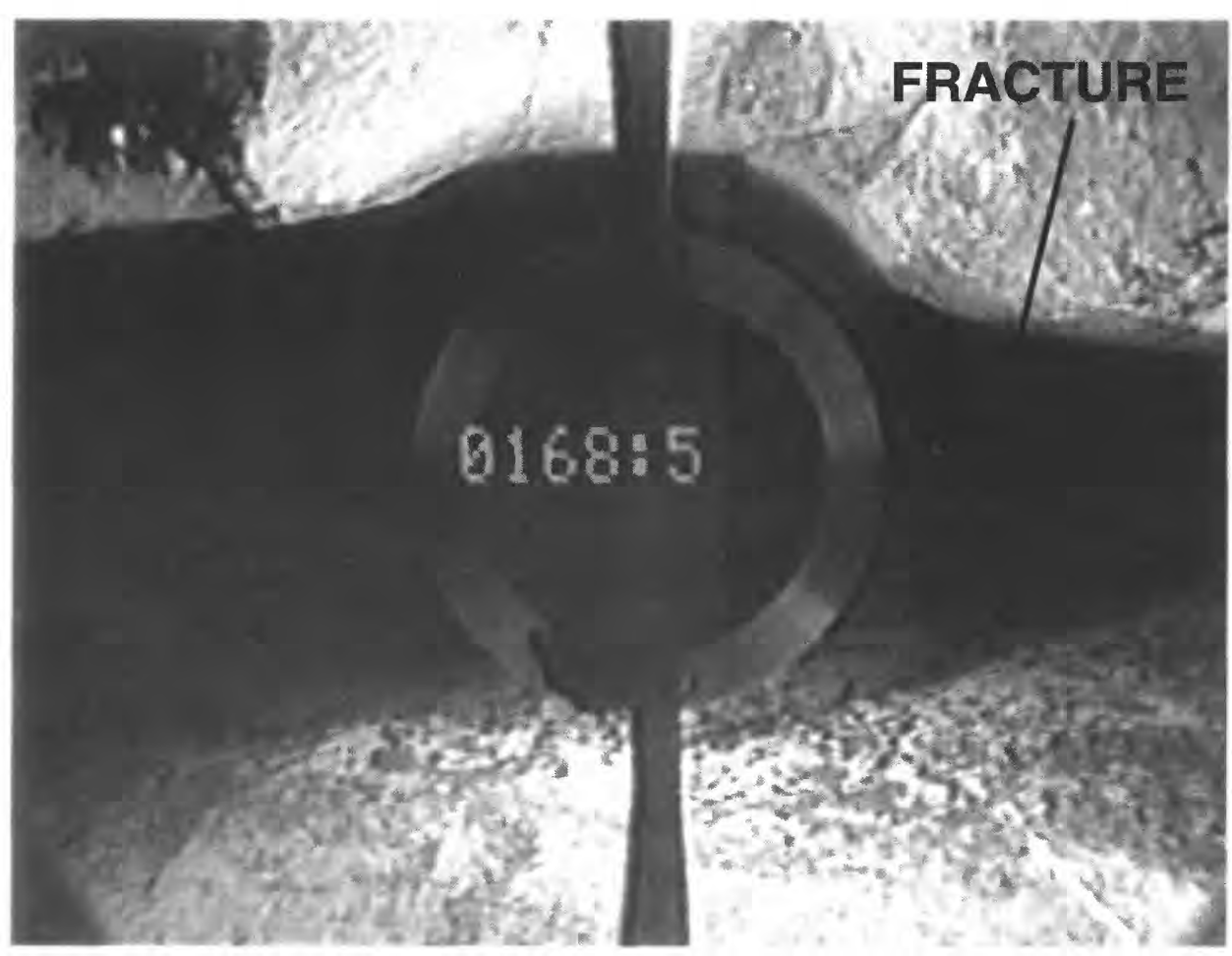

Figure 11. Photograph from borehole television survey of borehole BK-2597, Warminster Township, Pennsylvania, showing a nearly vertical fracture at 168.5 feet below land surface. 


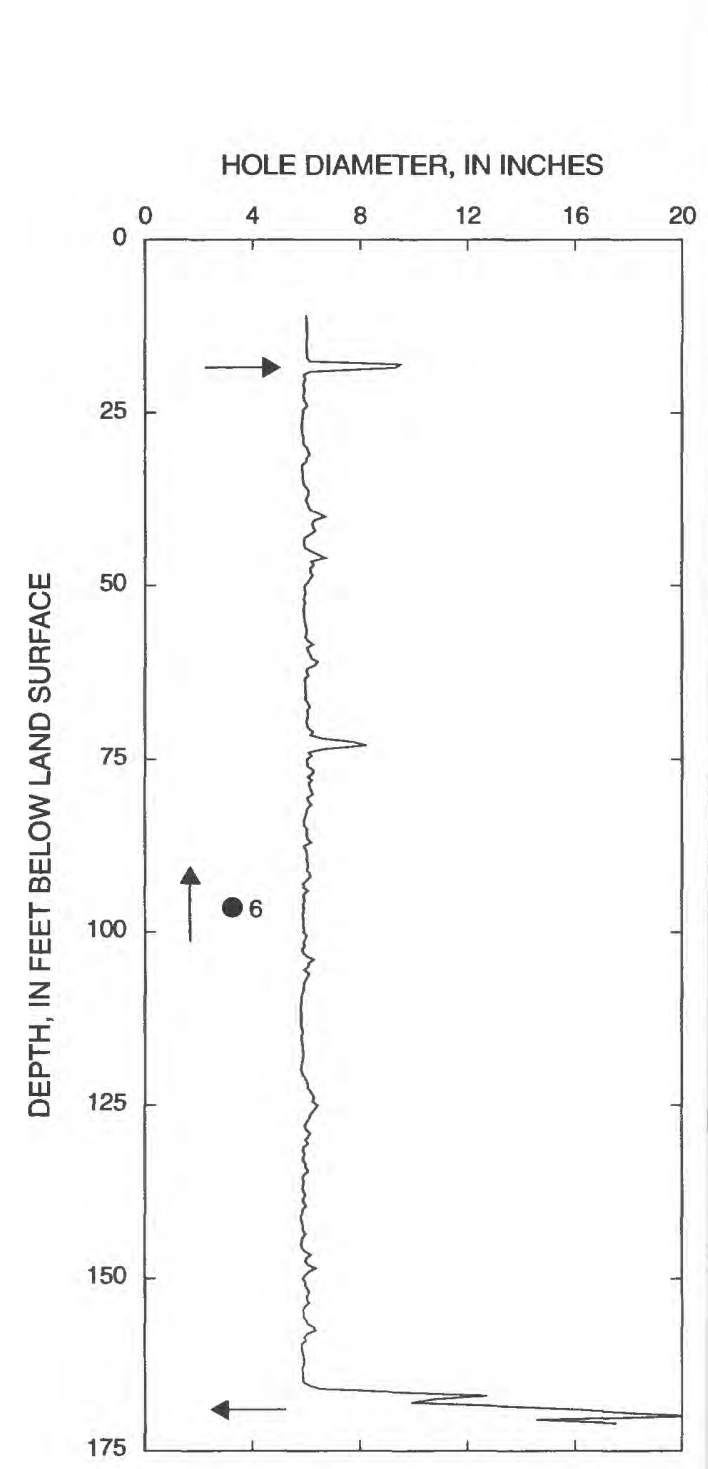

\section{EXPLANATION}

BOREHOLE-FLOW

MEASUREMENT-Circle at

depth of slug injection. Number

is measured flow in gallons per minute

DIRECTION OF VERTICAL BOREHOLE FLOW-ArroW indicates upward flow

FLOW INTO OR OUT OF BOREHOLE-Arrow pointing away from caliper log indicates flow into borehole. Arrow pointing toward caliper log indicates flow out of borehole

Figure 12. Caliper log from borehole BK-2597, Warminster Township, Pennsylvania, showing borehole-flow measurement.

Nearly all deep wells in the Stockton Formation are open to several water-bearing zones and are multiaquifer wells. Each water-bearing zone usually has a different hydraulic head. The hydraulic head in a deep, open-hole well is the composite of the heads in the several water-bearing zones penetrated. Where differences in hydraulic head exist between water-bearing zones, water in the well bore flows under nonpumping conditions in the direction of decreasing head.

Water-level measurements made at the MG-1222 monitor well cluster at the Raymark Site (fig. 2) on August 5, 1991, showed a water level $36.48 \mathrm{ft}$ bls for the open interval $33-63 \mathrm{ft}$ bls, a water level $49.91 \mathrm{ft}$ bls for the open interval $118-138 \mathrm{ft} \mathrm{bls}$, and a water level $55.85 \mathrm{ft}$ bls for the open interval 185-195 ft bls (fig. 13). At the
Raymark Site, water moves downward through the aquifer system in response to this downward head gradient, which is caused in part by the pumping of deep public supply wells.

The response of water levels in the MG-1222 monitor well cluster to the pumping of public supply well MG-944 (Hatboro-14), 3,800 ft away along strike, is shown in figure 14. The response of the water level in the deep monitor well (MG-1222), which is screened from 185 to $195 \mathrm{ft}$ bls, is very pronounced; the pumping schedule of well MG-944 can be clearly seen in the hydrograph. Pumping of well MG-944 caused daily water-level changes up to $2.53 \mathrm{ft}$ in well MG-1222. The response of the water level in the intermediate-depth monitor well, which is screened from 118 to $138 \mathrm{ft} \mathrm{bls,} \mathrm{to}$ the pumping of well MG-944 can be seen, but the daily change in water level is less than $0.15 \mathrm{ft}$. 

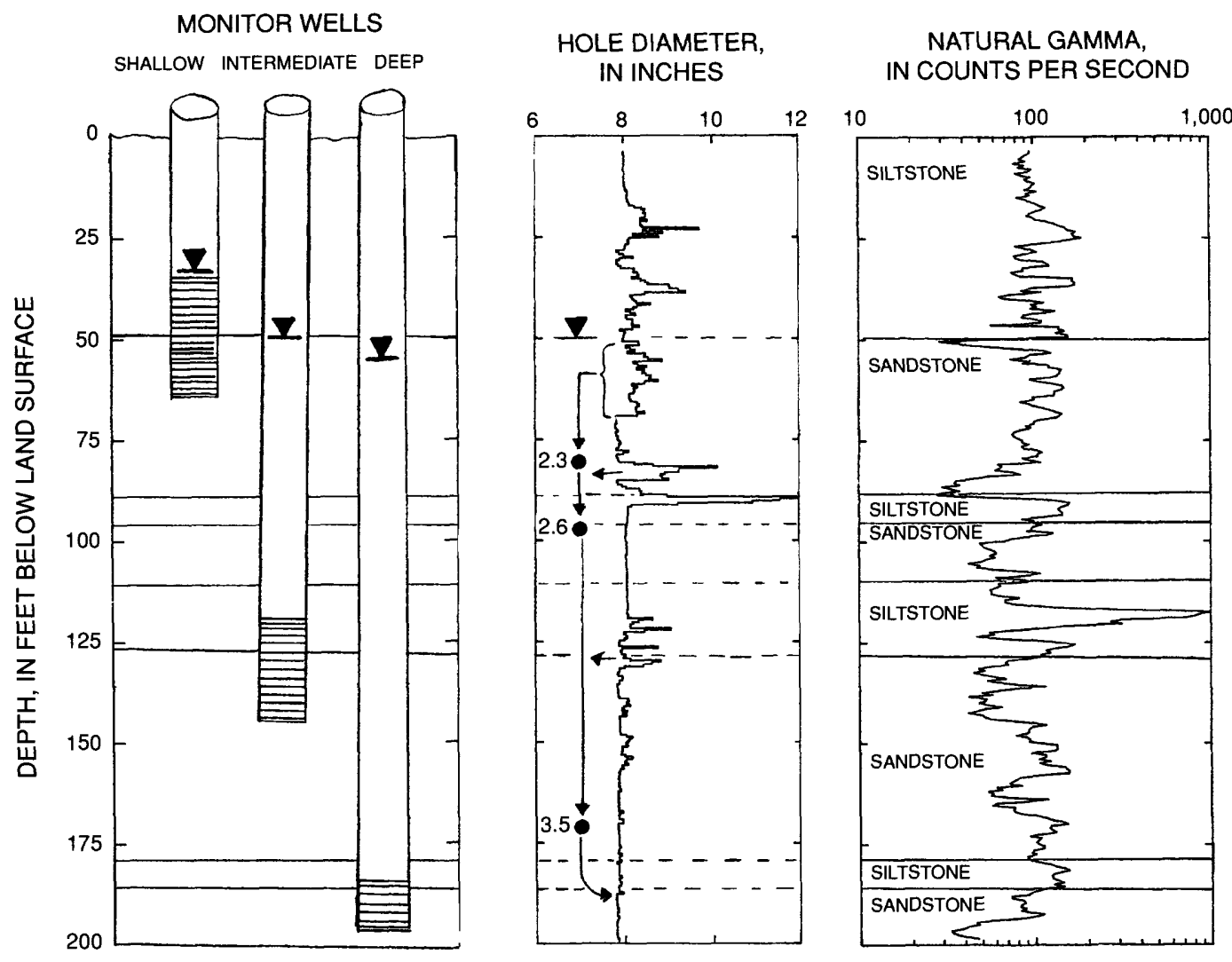

\section{EXPLANATION}

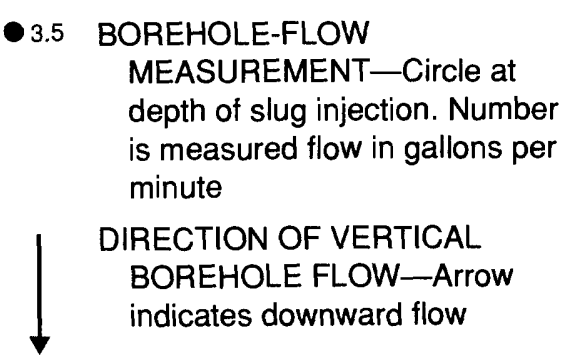
$\longrightarrow$ FLOW INTO OR OUT OF BOREHOLE-Arrow pointing away from caliper log indicates flow into borehole. Arrow pointing toward caliper log indicates flow out of borehole
1 MEASURED WATER LEVEL
SCREENED INTERVAL IN WELL

Figure 13. Caliper, natural-gamma, and generalized lithologic logs; screened intervals; boreholeflow measurements; and water levels for the MG-1222 monitor well cluster, Hatboro Borough, Pennsylvania. 


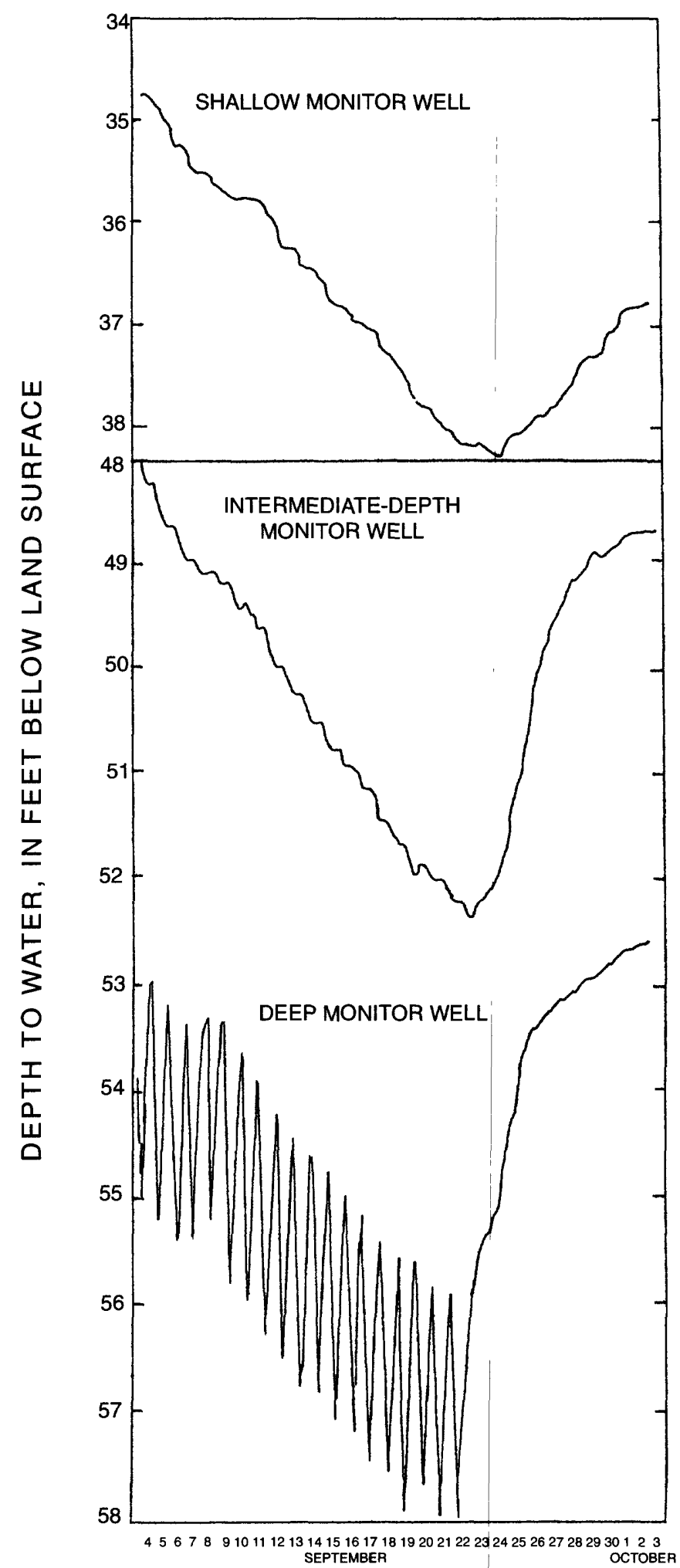

Figure 14. Hydrographs from the MG-1222 monitor well cluster, Hatboro Borough, Pennsylvania, September 4 to October 3, 1991. 
The water level in the shallow monitor well, which is screened from 33 to $63 \mathrm{ft}$ bls, does not show a daily water-level fluctuation caused by the pumping of well MG-944 but does show a rise in water level when well MG-944 stopped pumping. On September 23, pumping of well MG-944 ceased; the resultant recovery of water levels in each screened zone in the MG-1222 monitor well cluster also is shown on figure 14. Water levels recovered $5.47 \mathrm{ft}$ in the deep zone, $3.67 \mathrm{ft}$ in the intermediate-depth zone, and $1.47 \mathrm{ft}$ in the shallow zone. A downward head gradient is still present.

\section{Hydraulic Properties of the Rock Matrix}

Hydraulic properties of the rock matrix were determined in the laboratory from two cores collected at the Raymark Site. Borehole MG-1223 was cored from the land surface to $200 \mathrm{ft} \mathrm{bls,}$ and borehole MG-1283 was cored from 190 to $300 \mathrm{ft}$ bls.

The porosity of several lithologic units in the rock core from borehole MG-1223 was estimated from thin sections prepared from the core. Two slides were prepared from each of 10 core sections, one perpendicular to the core axis and one parallel to the core axis, to estimate porosity and other characteristics associated with or perpendicular to bedding planes. The thin sections were prepared with a blue epoxy resin for easy identification of pore spaces.
In the thin sections, all of the sandstone units are noticeably compacted, and the grains are partly crushed. Sutured grain boundaries are common, but all pore space is not eliminated. The siltstone units are extremely fine grained. Using an estimated percentage of pore space observed in two-dimensional space (horizontal and vertical directions), an approximate pore volume was calculated for each thin section (table 1).

Mean porosity is 3 percent for siltstone, 22.5 percent for silty, fine-grained sandstone, 9.6 percent for fine-grained sandstone, 8.6 percent for medium-grained sandstone, and 5.6 percent for coarse-grained sandstone (fig. 15). This is similar to laboratory porosity measurements made on rock samples from outcrops by Rima and others (1962, p. 29). Porosity is higher in the horizontal direction than in the vertical direction. Porosity generally increases with increasing grain size from siltstone to silty, fine-grained sandstone and then decreases with increasing grain size from silty, fine-grained sandstone to medium- to coarse-grained sandstone. Fine- and medium-grained sandstones are better sorted than the coarse-grained sandstones. Finer grained units exhibit a decrease in porosity as grain size decreases, most likely because of infilling of pore space by clay- and silt-sized particles. The medium-grained sandstone sample from 20 to $20.3 \mathrm{ft}$ bls has additional porosity created by dissolution from weathering of the unit. Rima and others (1962, p. 30) found that porosity

Table 1. Porosity estimated from thin sections of rock cores from boreholes MG-1223 and MG-1283, Hatboro Borough, Pennsylvania

$[<$, less than $]$

\begin{tabular}{ccccc}
\hline $\begin{array}{c}\text { Borehole } \\
\text { identification } \\
\text { number }\end{array}$ & $\begin{array}{c}\text { Depth } \\
\text { (feet below } \\
\text { land surface) }\end{array}$ & \multicolumn{1}{c}{ Lithology } & \multicolumn{2}{c}{$\begin{array}{c}\text { Porosity } \\
\text { (percent) }\end{array}$} \\
\hline MG-1223 & $20-20.3$ & Sandstone, gray, medium-grained, weathered & $\begin{array}{c}\text { Horizontal } \\
\text { direction }\end{array}$ & $\begin{array}{c}\text { Vertical } \\
\text { direction }\end{array}$ \\
MG-1223 & $23.7-24$ & Sandstone, gray, medium-grained & $20-25$ & 10 \\
MG-1223 & $34.3-34.5$ & Siltstone, reddish purple & 1 & 1 \\
MG-1223 & $54.6-54.8$ & Sandstone, silty, fine-grained & 3 \\
MG-1223 & $88.5-88.9$ & Sandstone, gray, fine-grained & 25 & 20 \\
MG-1223 & $104.2-104.4$ & Sandstone, gray, fine-grained, weathered & 25 \\
MG-1223 & $127.4-127.8$ & Siltstone & 5 & 10 \\
MG-1223 & $159.8-160$ & Siltstone to fine-grained sandstone & 1 \\
MG-1223 & $188.3-188.5$ & Sandstone, gray, medium- to coarse-grained & 1 & $7-10$ \\
MG-1283 & $224.5-224.7$ & Sandstone, gray, medium- to coarse-grained & $3-5$ \\
\hline
\end{tabular}




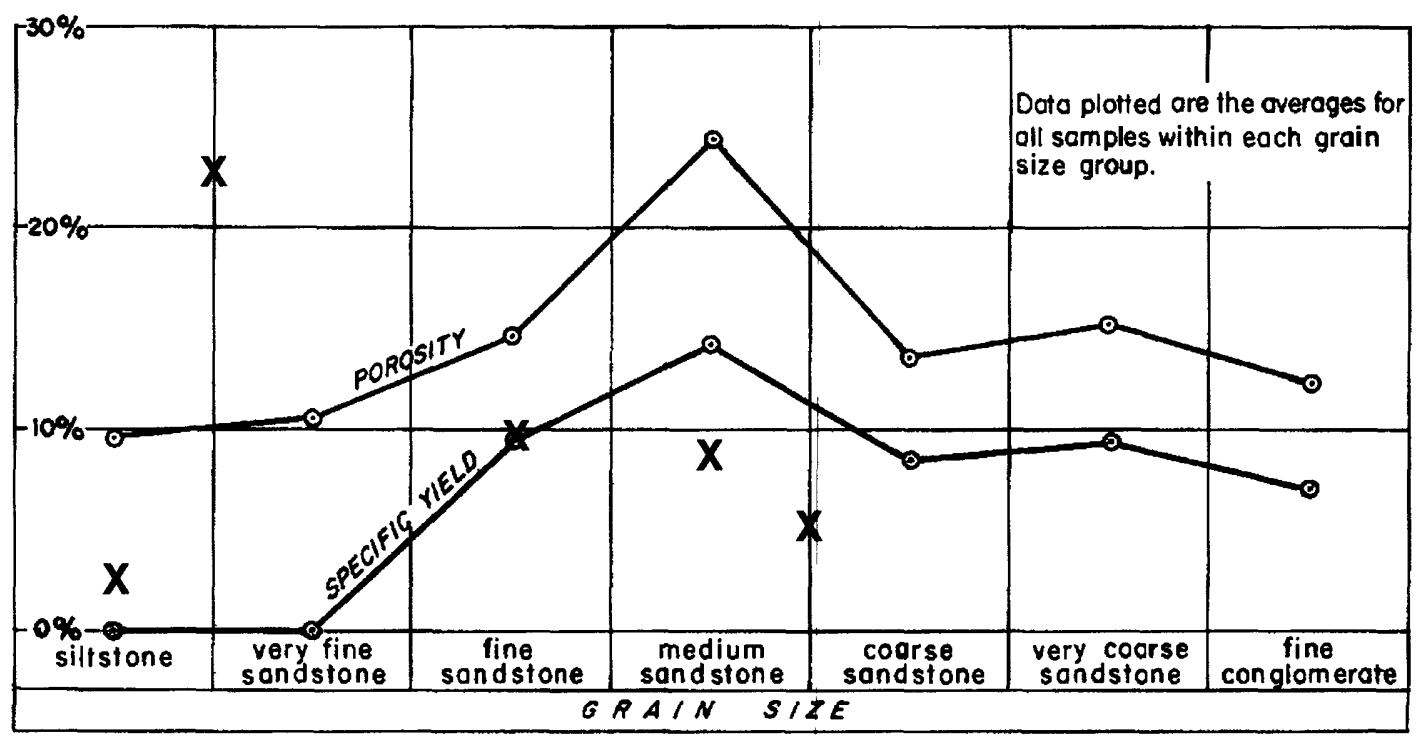

\section{EXPLANATION}

○ POROSITY AND SPECIFIC-YIELD DATA FROM

OUTCROP SAMPLES (RIMA AND OTHERS, 1962)

\section{POROSITY DATA FROM ROCK-CORE THIN
SECTIONS, THIS STUDY}

Figure 15. Porosity of the rock matrix determined from outcrop samples and rock-core thin sections. Modified from Rima and others (1962, p. 29).

was consistently greater than the specific yield for each lithologic unit, which means that the aquifer will not yield to gravity flow all of the water contained in the pore spaces.

Laboratory hydraulic conductivity measurements were made on three sections of the rock core from borehole MG-1223 and one section of the rock core from borehole MG-1283 (table 2). The tests followed the procedures developed by Olsen and others (1991). Hydraulic conductivity ranges more than seven orders of magnitude. The core samples, except one, were very smooth and were unsaturated. The core section, a sandstone unit from 224.5 to $224.7 \mathrm{ft}$ bls that had the highest laboratory hydraulic conductivity, had a grainy feel and was saturated, showing some primary porosity. Deep monitor wells at the Raymark Site penetrate this sandstone unit. The combination of primary and secondary porosity of this unit enables the strong hydraulic connection with public supply well MG-944 shown on figure 14 .
Table 2. Hydraulic conductivity determined in the laboratory from rock cores from boreholes MG-1223 and MG-1283, Hatboro Borough, Pennsylvania

\begin{tabular}{|c|c|c|c|}
\hline $\begin{array}{c}\text { Borehole } \\
\text { identification } \\
\text { number }\end{array}$ & $\begin{array}{c}\text { Depth } \\
\text { (feet below } \\
\text { land surface) }\end{array}$ & Lithology & $\begin{array}{c}\text { Hydraulic } \\
\text { conductivity } \\
\text { (feet per day) }\end{array}$ \\
\hline MG -1223 & $86.1-86.3$ & $\begin{array}{l}\text { Sandstone, gray, } \\
\text { fine-grained }\end{array}$ & $1.18 \times 10^{-4}$ \\
\hline MG -1223 & $130.0-130.2$ & $\begin{array}{l}\text { Sandstone, red, } \\
\text { silty, fine-grained }\end{array}$ & $2.92 \times 10^{-6}$ \\
\hline $\mathrm{MG}-1223$ & $161.0-161.2$ & Siltstone, red & $5.14 \times 10^{-7}$ \\
\hline MG -1283 & $224.5-224.7$ & $\begin{array}{l}\text { Sandstone, gray, } \\
\text { medium- to } \\
\text { coarse-grained }\end{array}$ & 0.19 \\
\hline
\end{tabular}

\section{Borehole-Flow Measurements}

Measurements of vertical fluid movement in boreholes under nonpumping conditions were made in 93 boreholes in the study area. Slugs of highconductance fluid were injected in 83 boreholes at different depths to determine the direction and rate of borehole flow (brine-tracing method). As many as nine slugs were injected in a single borehole. Fluid 
movement at rates up to $17 \mathrm{gal} / \mathrm{min}$ was measured. No flow was measurable in 18 boreholes. The direction and rate of borehole flow were indeterminable for nine boreholes by use of the brine-tracing method. Difficulty in determining borehole flow is caused by horizontal flow through the formation, low velocities caused by large-diameter boreholes (up to $14 \mathrm{in.} \mathrm{in}$ diameter), rough-sided boreholes, and fast slug movement. A heat-pulse flowmeter was used to measure borehole flow in 10 boreholes.

The predominant direction of vertical borehole flow measured in Hatboro Borough and in Warminster Township near the Fischer and Porter Site is downward, primarily caused by a downward head gradient formed in response to the pumping of public supply wells in the area. Downward flow was measured in 36 boreholes, not including those boreholes in which two directions of flow were measured. These boreholes ranged from 149 to $510 \mathrm{ft}$ in depth. Generally, fluid movement is downward from fractures in the siltstone and sandstone units in the upper part of the aquifer system, which is unconfined, to fractures in the sandstone units in the lower part of the aquifer system, which is semiconfined or confined. The fluid movement measured in borehole MG-1236 is shown in figure 16. Water cascades into the borehole at $0.8 \mathrm{gal} / \mathrm{min}$ from a fracture at $16.5 \mathrm{ft} \mathrm{bls}$, which is above the water level. An additional $5.2 \mathrm{gal} / \mathrm{min}$ of water enters the borehole through a fracture at $70 \mathrm{ft} \mathrm{bls}$ and moves downward. Water exits the borehole through fractures at $96 \mathrm{ft}(1.4 \mathrm{gal} / \mathrm{min}), 125 \mathrm{ft}$ (2.6 gal/min), and $150 \mathrm{ft}$ ( $2 \mathrm{gal} / \mathrm{min}) \mathrm{bls}$.

Upward vertical flow was measured in 23 boreholes, which ranged from 71 to $591 \mathrm{ft}$ deep. Many of these boreholes are just northwest of the topographic divide between the Pennypack and Little Neshaminy Creek drainage basins. The divide approximately parallels the strike of the Stockton Formation, and boreholes northwest of the divide penetrate younger beds that crop out in upsection, upgradient areas. The fluid movement measured in borehole BK-2600 is shown in figure 17. Water enters the borehole at a rate of $4.4 \mathrm{gal} / \mathrm{min}$ through fractures at $126-129 \mathrm{ft}$ bls and moves upward. An additional $0.3 \mathrm{gal} / \mathrm{min}$ enters the borehole through a fracture at $93 \mathrm{ft}$ bls. Water exits the borehole through fractures at $50.5 \mathrm{ft}(3.5 \mathrm{gal} / \mathrm{min})$ and $28 \mathrm{ft}(1.2 \mathrm{gal} / \mathrm{min})$ bls.

Both upward and downward vertical flow was measured in six boreholes. These boreholes ranged from 396 to $470 \mathrm{ft}$ deep and were among the deepest boreholes logged. Fluid movement was upward in the upper part of the borehole and downward in the lower part of the borehole in two boreholes. The fluid movement measured in borehole $\mathrm{BK}-1845$ is shown in figure 18. Borehole $\mathrm{BK}-1845$ is about $100 \mathrm{ft}$ from Little Neshaminy Creek, and the expected head gradient would be upward in a discharge area. Water enters the borehole at a rate of $1.9 \mathrm{gal} / \mathrm{min}$ through a fracture at $340 \mathrm{ft}$ bls and moves upward at a rate of $1.2 \mathrm{gal} / \mathrm{min}$ and downward at a rate of $0.7 \mathrm{gal} / \mathrm{min}$. Water exits the borehole through a fracture at the bottom of the borehole. Additional water enters the borehole through fractures at $236 \mathrm{ft}(1.7 \mathrm{gal} / \mathrm{min})$ and about $165 \mathrm{ft}(2.1 \mathrm{gal} / \mathrm{min})$ bls and moves upward. Water exits the borehole at a rate of $5 \mathrm{gal} / \mathrm{min}$ through a fracture at $49 \mathrm{ft}$ bls, just below the casing.

Fluid movement was downward in the upper part of the borehole and upward in the lower part of the borehole in three boreholes. The fluid movement measured in borehole BK-949 is shown in figure 19 . In the upper part of the borehole, water enters at a rate of $2 \mathrm{gal} / \mathrm{min}$ through a fracture at $126 \mathrm{ft}$ bls and moves downward. An additional $2.9 \mathrm{gal} / \mathrm{min}$ of water enters the borehole through fractures at 169-174 ft bls. Water exits the borehole through fractures at $188 \mathrm{ft}$ $(1.5 \mathrm{gal} / \mathrm{min})$ and $220 \mathrm{ft}(3.4 \mathrm{gal} / \mathrm{min}) \mathrm{bls}$. In the lower part of the borehole, water enters at a rate of $1.4 \mathrm{gal} / \mathrm{min}$ through a fracture at $384 \mathrm{ft} \mathrm{bls}$, moves upward, and exits the borehole through fractures at 303-307 ft bls. A zone of no borehole flow between 220 and $303 \mathrm{ft}$ bls separates the two zones of flow.

Fluid movement in some boreholes is very complex. The fluid movement in borehole BK-2794 was measured by use of a heat-pulse flowmeter (fig. 20). The heat-pulse-flowmeter measurements show two zones of upward flow with a zone of downward flow between them. Water enters the borehole at a rate of $0.26 \mathrm{gal} / \mathrm{min}$ through a fracture at $111 \mathrm{ft}$ bls and moves upward at a rate of $0.18 \mathrm{gal} / \mathrm{min}$ and downward at a rate of $0.8 \mathrm{gal} / \mathrm{min}$. Water also enters the borehole at a rate of $0.02 \mathrm{gal} / \mathrm{min}$ through a fracture at $212 \mathrm{ft}$ bls and moves upward. Water moving downward from the fracture at $111 \mathrm{ft}$ bls and upward from the fracture at $212 \mathrm{ft}$ bls exits the borehole through a fracture at $147 \mathrm{ft}$ bls. Water moving upward from the fracture at $111 \mathrm{ft}$ bls exits the borehole through fractures at $70 \mathrm{ft}(0.11 \mathrm{gal} / \mathrm{min}), 60 \mathrm{ft}(0.06 \mathrm{gal} / \mathrm{min})$, and $28 \mathrm{ft}(0.03 \mathrm{gal} / \mathrm{min}) \mathrm{bls}$. 


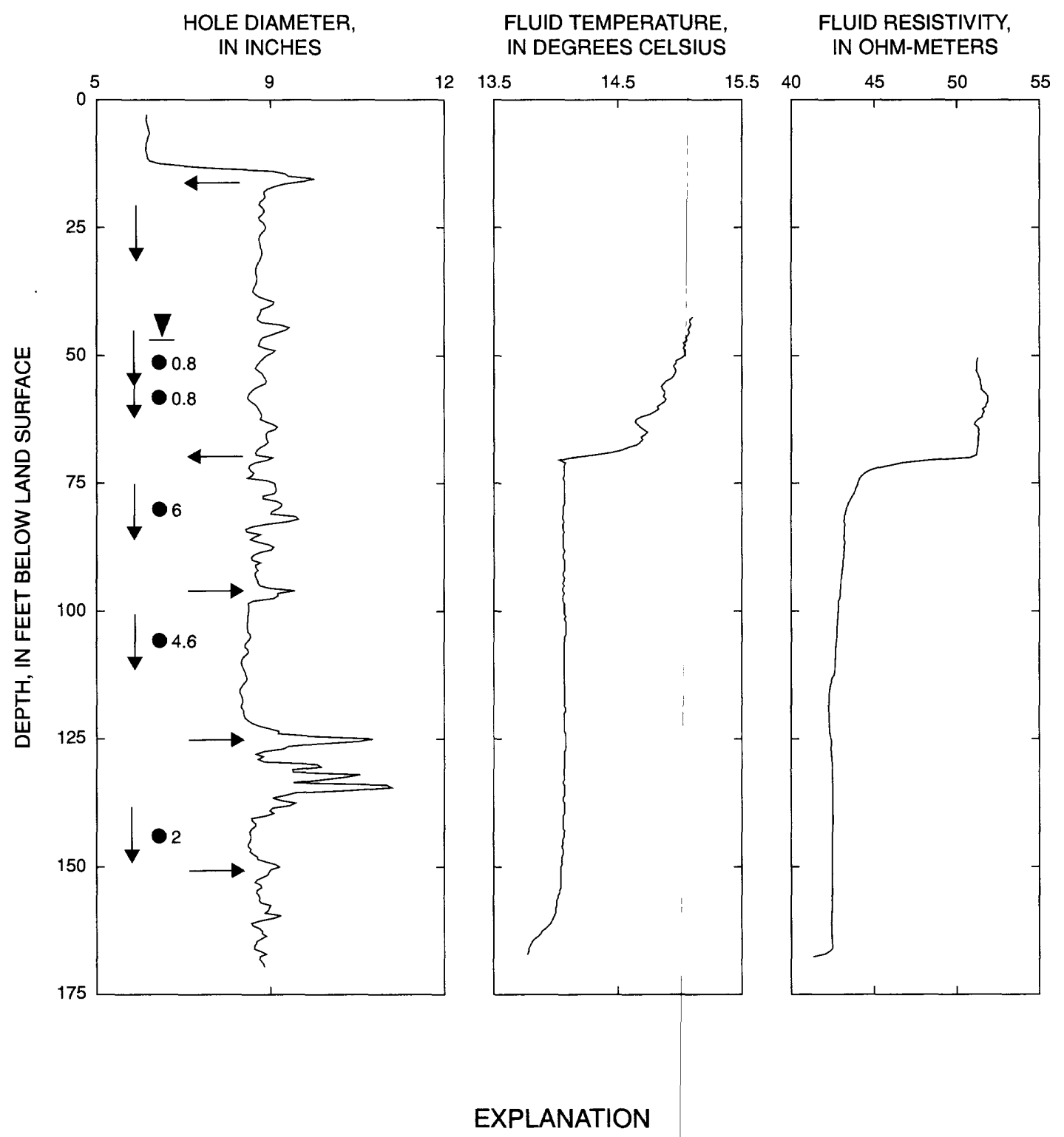

Figure 16. Caliper, fluid-temperature, and fluid-resistivity logs from borehole MG-1236, Hatboro Borough, Pennsylvania, showing borehole-flow measurements. 


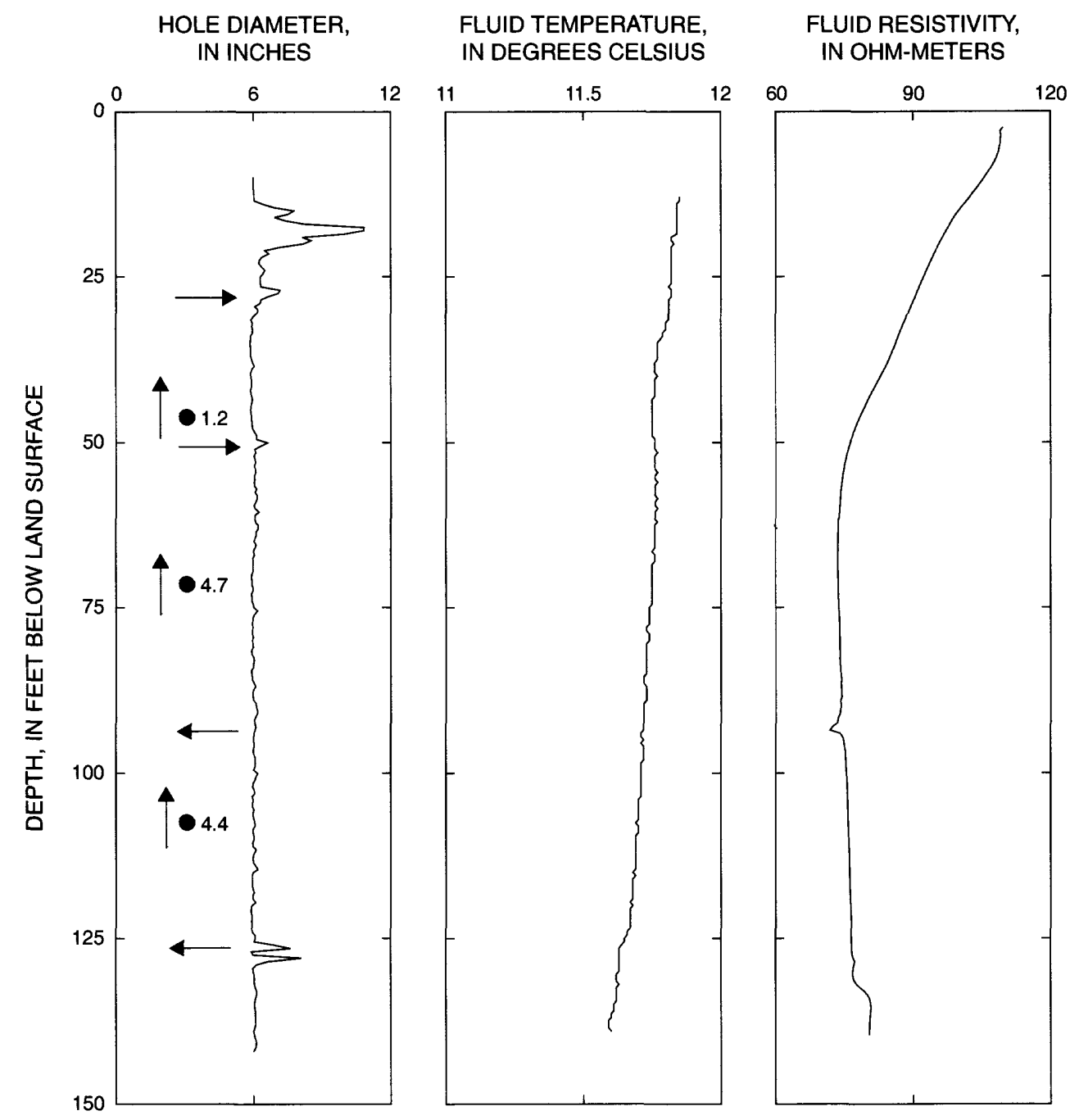

EXPLANATION

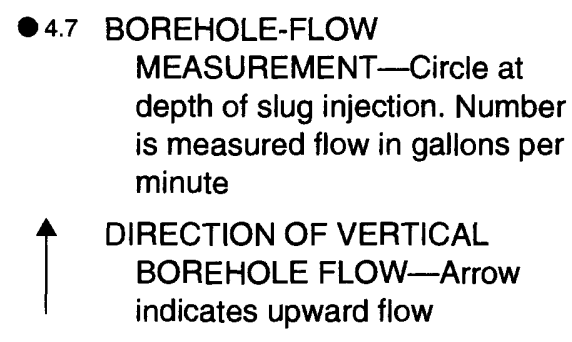
$\longrightarrow$ FLOW INTO OR OUT OF BOREHOLE-Arrow pointing away from caliper log indicates flow into borehole. Arrow pointing toward caliper log indicates flow out of borehole

Figure 17. Caliper, fluid-temperature, and fluid-resistivity logs from borehole BK-2600, Warminster Township, Pennsylvania, showing borehole-flow measurements. 


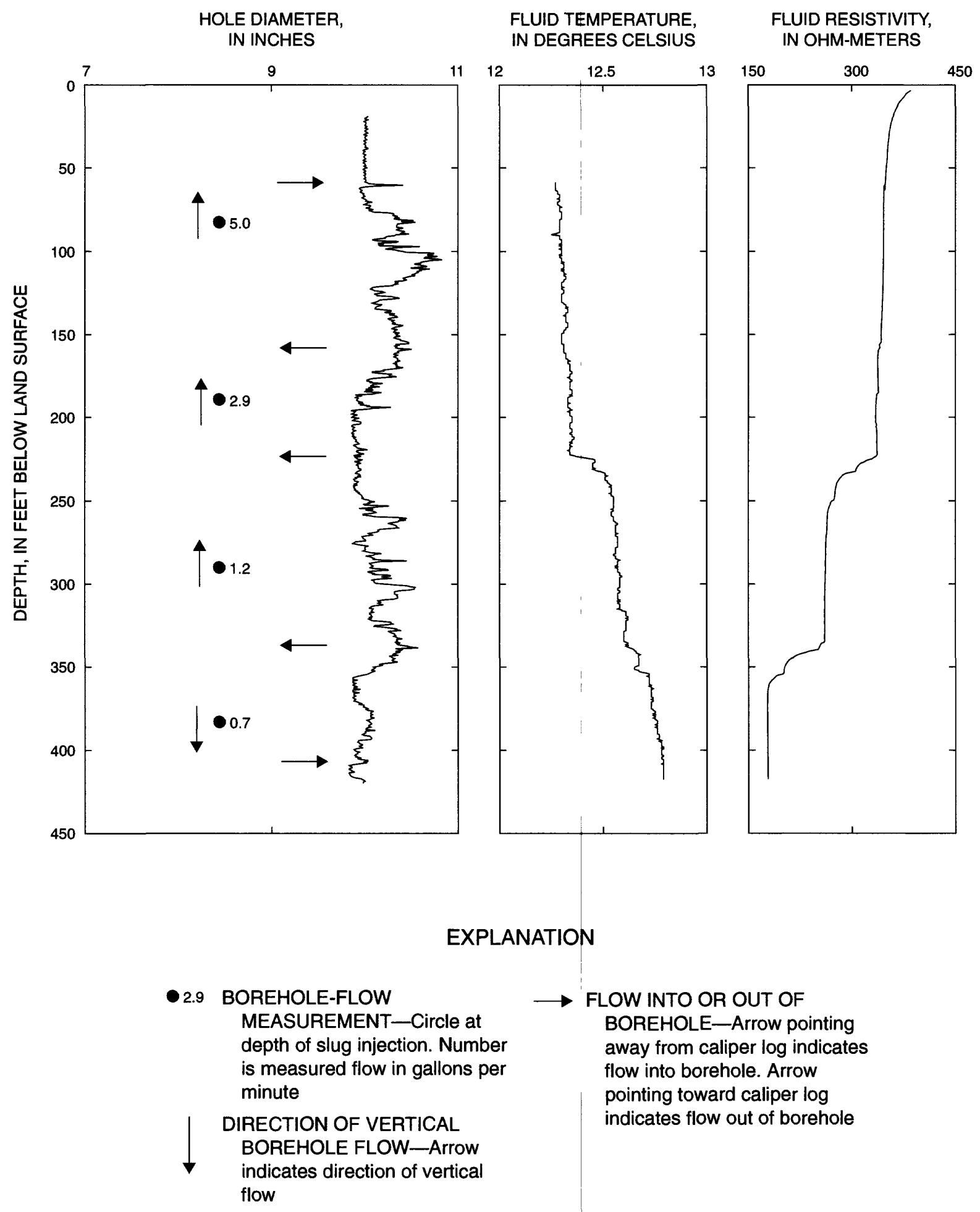

Figure 18. Caliper, fluid-temperature, and fluid-resistivity logs from borehole BK-1845, Warwick Township, Pennsylvania, showing borehole-flow measurements. 


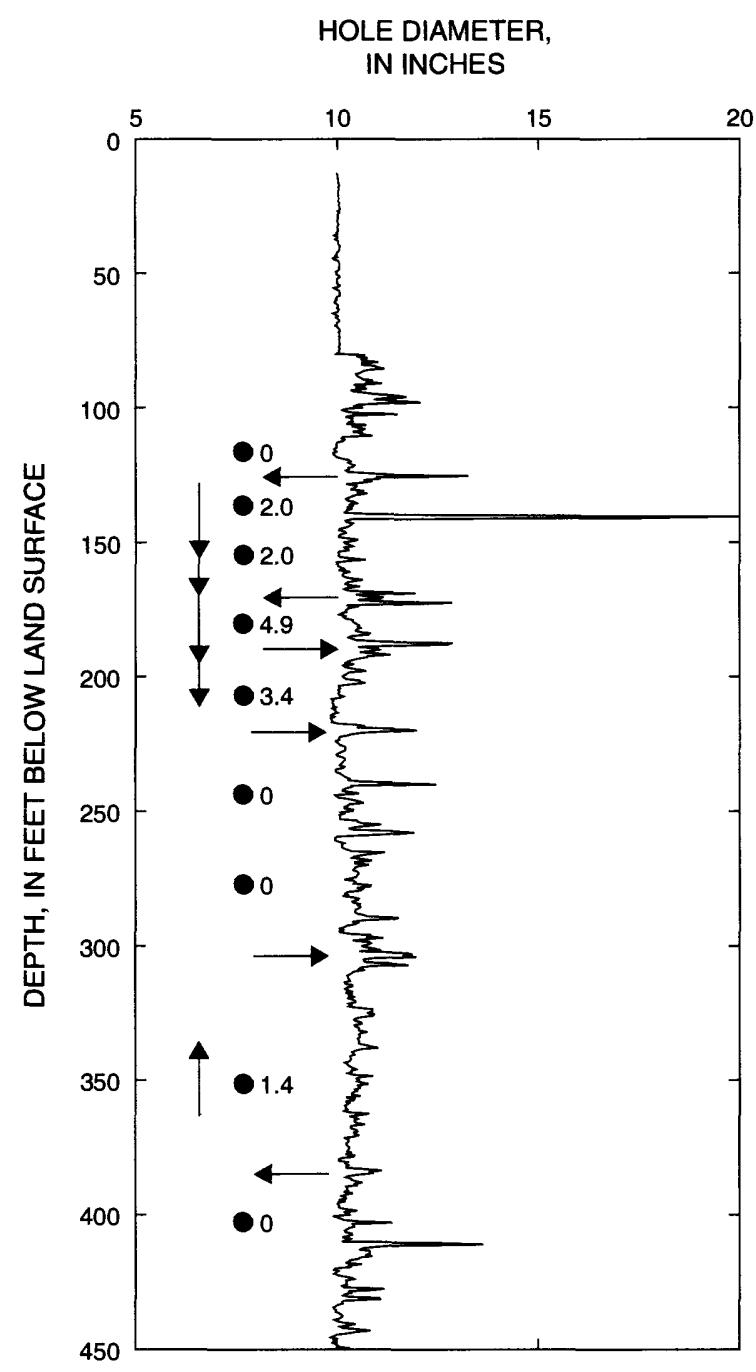

FLUID TEMPERATURE,

FLUID RESISTIVITY, IN DEGREES CELSIUS

IN OHM-METERS
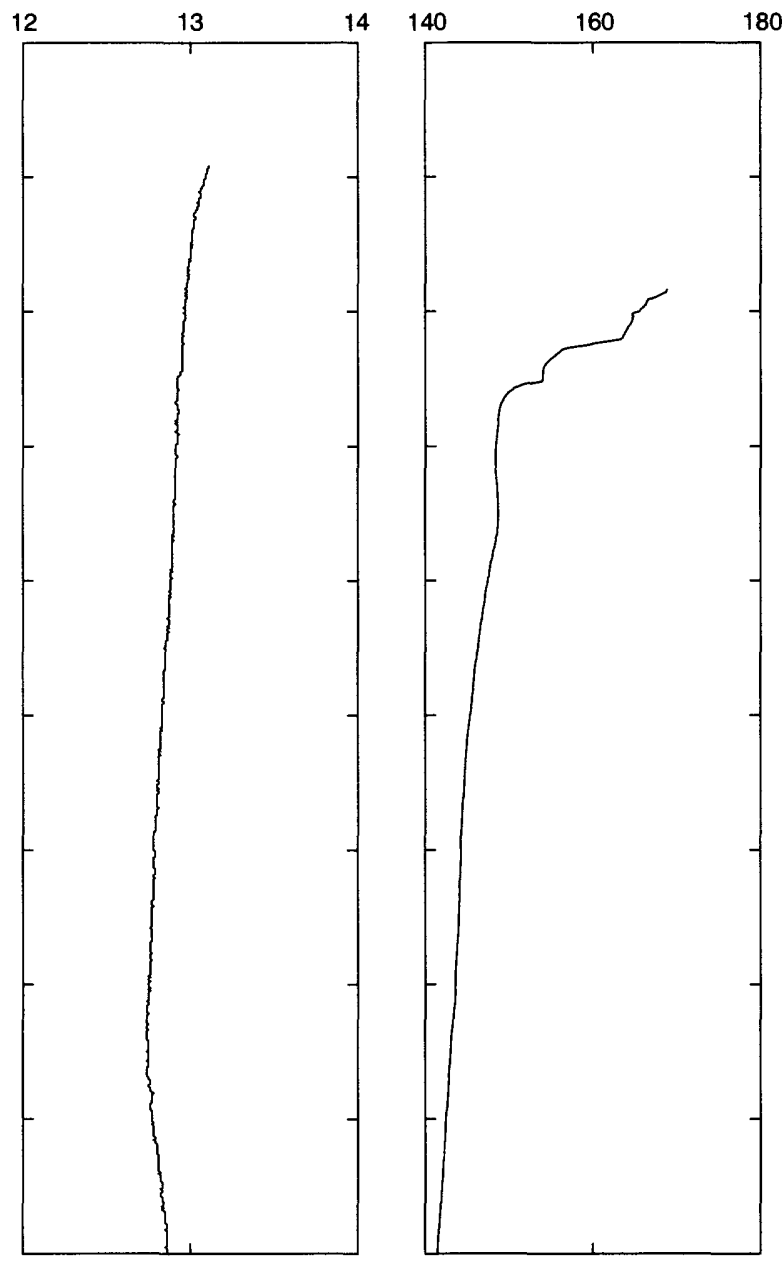

\section{EXPLANATION}

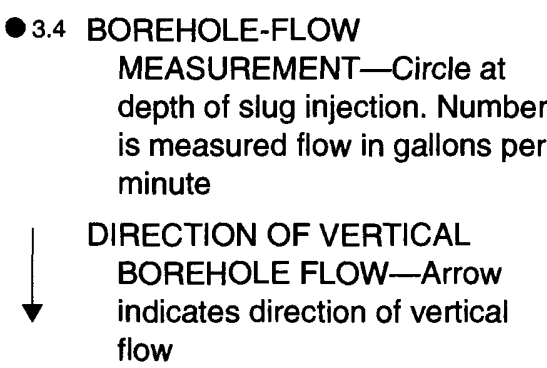
$\longrightarrow$ FLOW INTO OR OUT OF BOREHOLE-Arrow pointing away from caliper log indicates flow into borehole. Arrow pointing toward caliper log indicates flow out of borehole

Figure 19. Caliper, fluid-temperature, and fluid-resistivity logs from borehole BK-949, Warminster Township, Pennsylvania, showing borehole-flow measurements. 


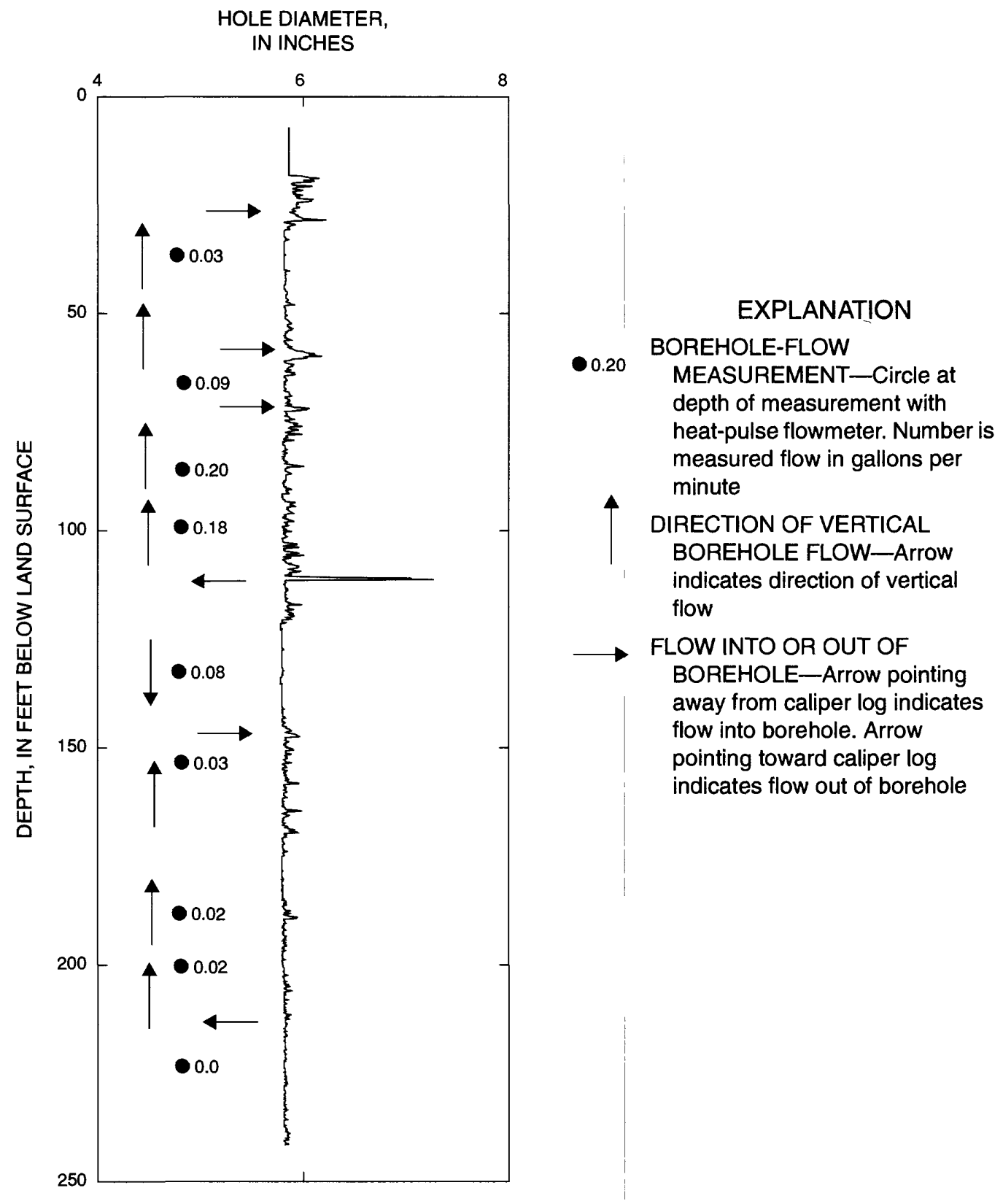

Figure 20. Caliper log from borehole BK-2794, Warminster Township, Pennsylvania, showing borehole-flow measurements made with a heat-pulse flowmeter.

\section{Ground-Water Quality}

Water samples were collected for field and laboratory analysis from 24 boreholes with measurable borehole flow. More than one depth interval was sampled in four boreholes. Water samples also were collected from 14 pumping wells, mostly active public supply wells in the Hatboro Authority water system.
Well MG-1235 was sampled after 47 hours of pumping during a 48-hour aquifer test. Well-construction data are listed in table 6 at the back of this report. Water samples were analyzed for some chemical and physical properties ( $\mathrm{pH}$, temperature, specific conductance, alkalinity, and dissolved oxygen) in the field. Samples were analyzed for selected dissolved 
inorganic constituents, nutrients, and radon and total VOC's by the USGS National Water-Quality Laboratory in Arvada, Colo. Results of field determinations and chemical analyses are listed in tables 7-9 at the back of this report.

\section{Inorganic Constituents}

Ground-water samples were grouped by shallow borehole-flow samples (samples collected at depths less than $85 \mathrm{ft}$ bls, 13 samples), deep borehole-flow samples (samples collected at depths greater than $90 \mathrm{ft}$ bls, 12 samples), and pumping-well samples (active public supply wells, 15 samples). Shallow borehole-flow samples were assumed to represent ground water with a short flow path and residence time. Deep borehole-flow samples were assumed to represent ground water with an intermediate flow path and residence time. Pumping-well samples were assumed to represent ground water with a long flow path and residence time.

Ground water in the Stockton Formation is predominantly of the calcium bicarbonate type; shallow borehole-flow samples contain less calcium and bicarbonate than the other samples (fig. 21), probably because calcite $\left(\mathrm{CaCO}_{3}\right)$ has been leached from the shallow part of the aquifer system. The water sample from borehole MG-1240 plots as a sodium chloride type of water because the borehole is at a former road-salt storage site, and the water from this borehole is contaminated with road de-icing salt; the concentration of chloride is $240 \mathrm{mg} / \mathrm{L}$. Water from public supply wells MG-946 (Hatboro-16) and MG-947 (Hatboro-17), near MG-1240, also contains elevated concentrations of chloride $(93 \mathrm{mg} / \mathrm{L}$ and $83 \mathrm{mg} / \mathrm{L}$, respectively), suggesting that part of the source area for water pumped from wells MG-946 and MG-947 is updip to the southeast.

The interaction between water and the rocks of the Stockton Formation was evaluated by use of the SOLMINEQ.88 geochemical modeling computer program of Kharaka and others (1988). The model computes the equilibrium distribution of inorganic aqueous species generally present in ground water by use of interpolated disassociation constants and computed activity coefficients. States of reaction of the aqueous solution with respect to 220 solid phases (minerals) are computed from the distribution of aqueous species by use of a consistent set of thermodynamic data.

Model results showed little difference between shallow and deep borehole-flow samples or between borehole-flow samples and pumping-well samples. These results indicate that most cations and anions in ground water probably have their source in the weathered upper few feet or tens of feet of the formation. Nearly all ground-water samples were saturated with respect to minerals of the smectite group (illite, kaolinite, dickite, and pyrophyllite), gibbsite, and halloysite. These minerals are predominant in the soil of the study area. Soil analyses in the study area give the average mineral composition as 33-36 percent illite, 30-32 percent montmorillonite (a smectite group mineral), 21-24 percent kaolinite, 14-17 percent vermiculite, and 5 percent chlorite (Tompkins, 1975). Gibbsite and halloysite are secondary minerals derived from the weathering of aluminum silicates.

Nearly all ground-water samples also were saturated with respect to albite, microcline, quartz, potassium feldspar, muscovite, and paragonite (sodium-rich mica). The average composition of nine arkose samples from the Stockton Formation given by Rima and others $(1962$, p. 17) was 62 percent quartz, 34 percent feldspar, and 1 percent mica. Feldspar minerals from the Stockton Formation, in order of decreasing abundance, are orthoclase, microcline, albite, oligoclase, perthite, and microperthite. Matrixes are of three distinct types: (1) kaolinite-illite and hematite; (2) chlorite, sericite (fine-grained muscovite), and pulverized quartz grains; and (3) finely disseminated sericite. The cementing materials are authigenic quartz, authigenic feldspar, and carbonates, chiefly calcite (Rima and others, 1962, p. 20).

\section{Volatile Organic Compounds}

Trichloroethylene (TCE), tetrachloroethylene (PCE), and 1,1,1-trichloroethane (TCA) are among the most commonly used industrial solvents. Besides these compounds, several other organic compounds not commonly used in the study area 


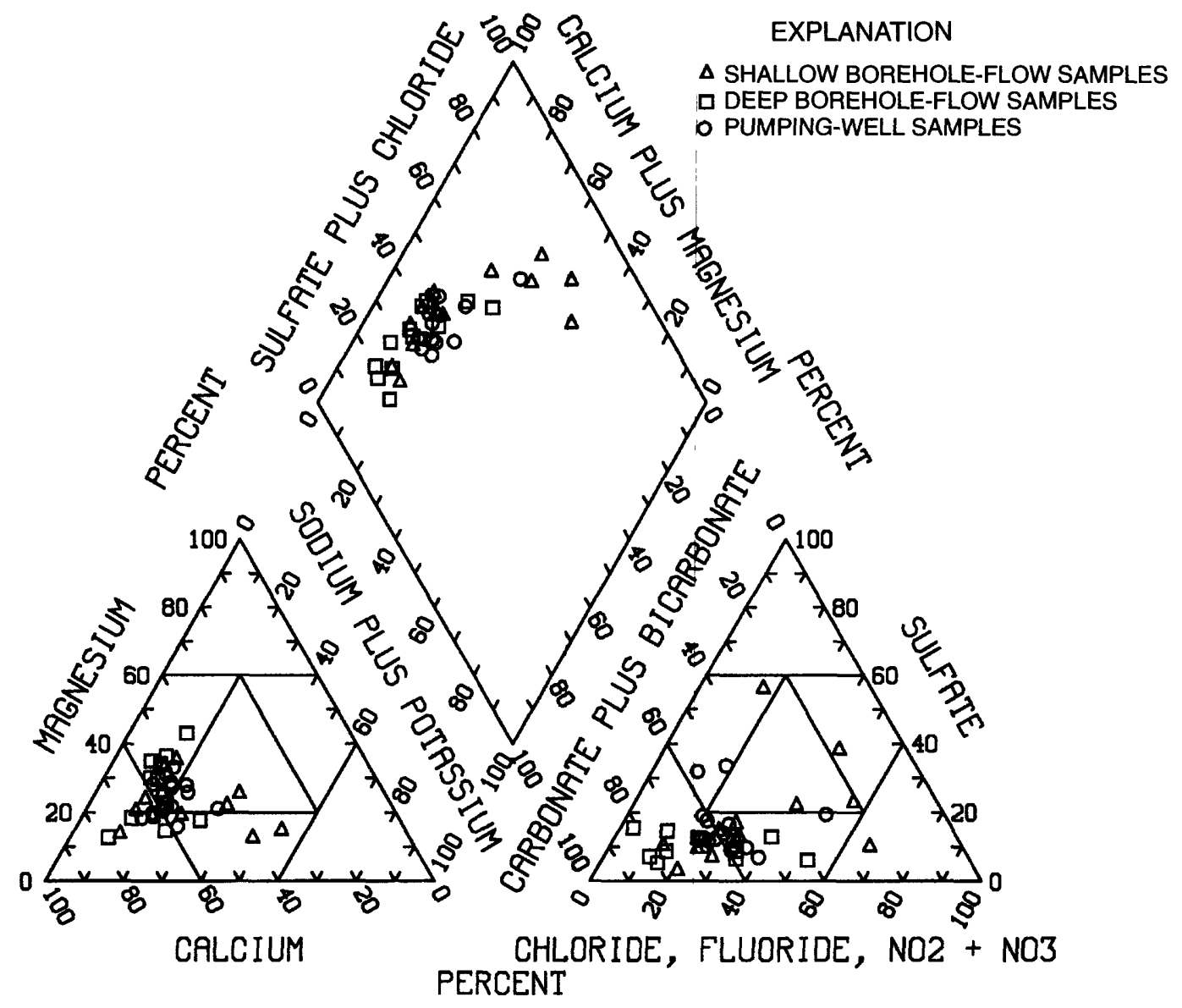

Figure 21. Piper diagram of cation-anion percentages for pumping-well, shallow boreholeflow, and deep borehole-flow water samples, Hatboro Borough and Warminster Township, Pennsylvania.

are found in ground water. Compounds, such as trans-1,2-dichloroethene (DCE), 1,1-dichloroethane (DCA), and vinyl chloride (VC), are degradation products of other VOC's. Under anaerobic conditions, PCE successively degrades by reductive dehalogenation to TCE; cis-1,2-DCE, trans-1,2-DCE, and (or) 1,1-DCE; chloroethane; and VC (Parsons and others, 1985; Vogel and McCarty, 1985; Freedman and Gossett, 1989). TCA anaerobically degrades to DCA. A typical reaction pathway for anaerobic degradation of PCE and TCE by reductive dehalogenation is shown in figure 22 .

Ground-water contamination by VOC's is widespread in the study area. Detectable concentrations of VOC's were present in water samples from all 24 wells sampled in Hatboro Borough and in water samples from 10 of 14 wells ( 71 percent) sampled in Warminster Township (fig. 23). The VOC's detected in water samples are summarized in table 3. Of 43 VOC's analyzed for, 20 compounds (47 percent) were detected. Chloroform was the most commonly detected VOC ( 28 wells or 74 percent of wells sampled), followed by TCE ( 26 wells or 68 percent), and PCE and TCA ( 24 wells or 63 percent). Chloroform is a common laboratory contaminant, and if it is present in ground water, the source may be leaking water-distribution and sewer lines. Most of the study area is supplied with public water and sewers. 


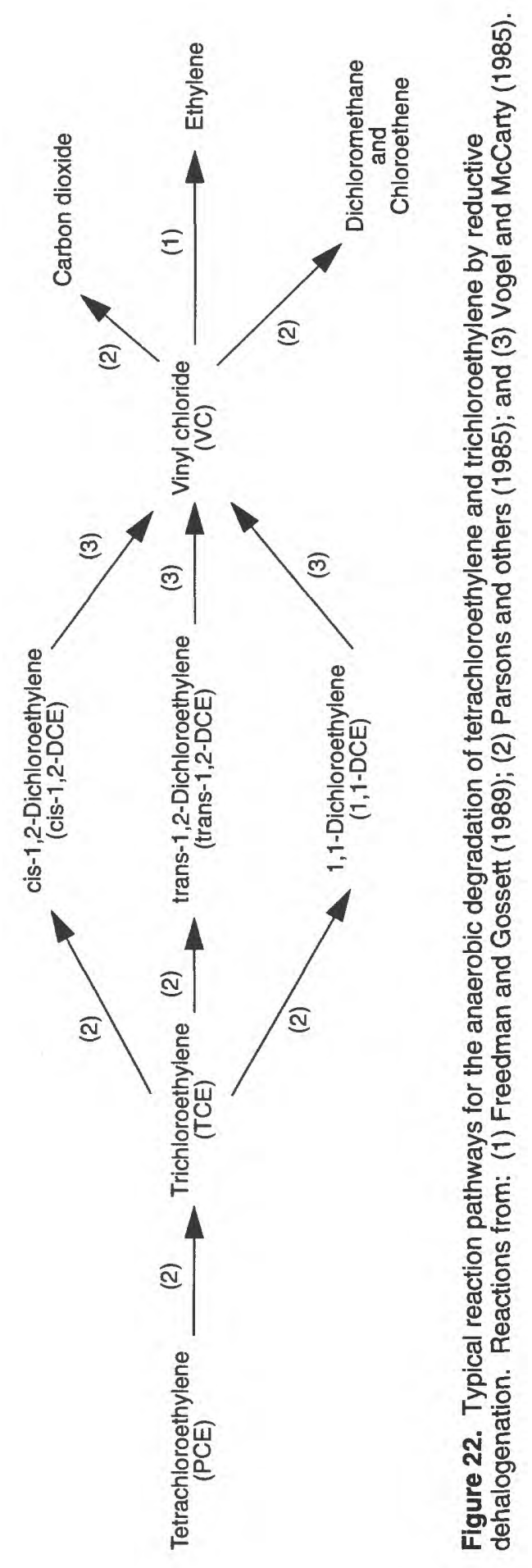




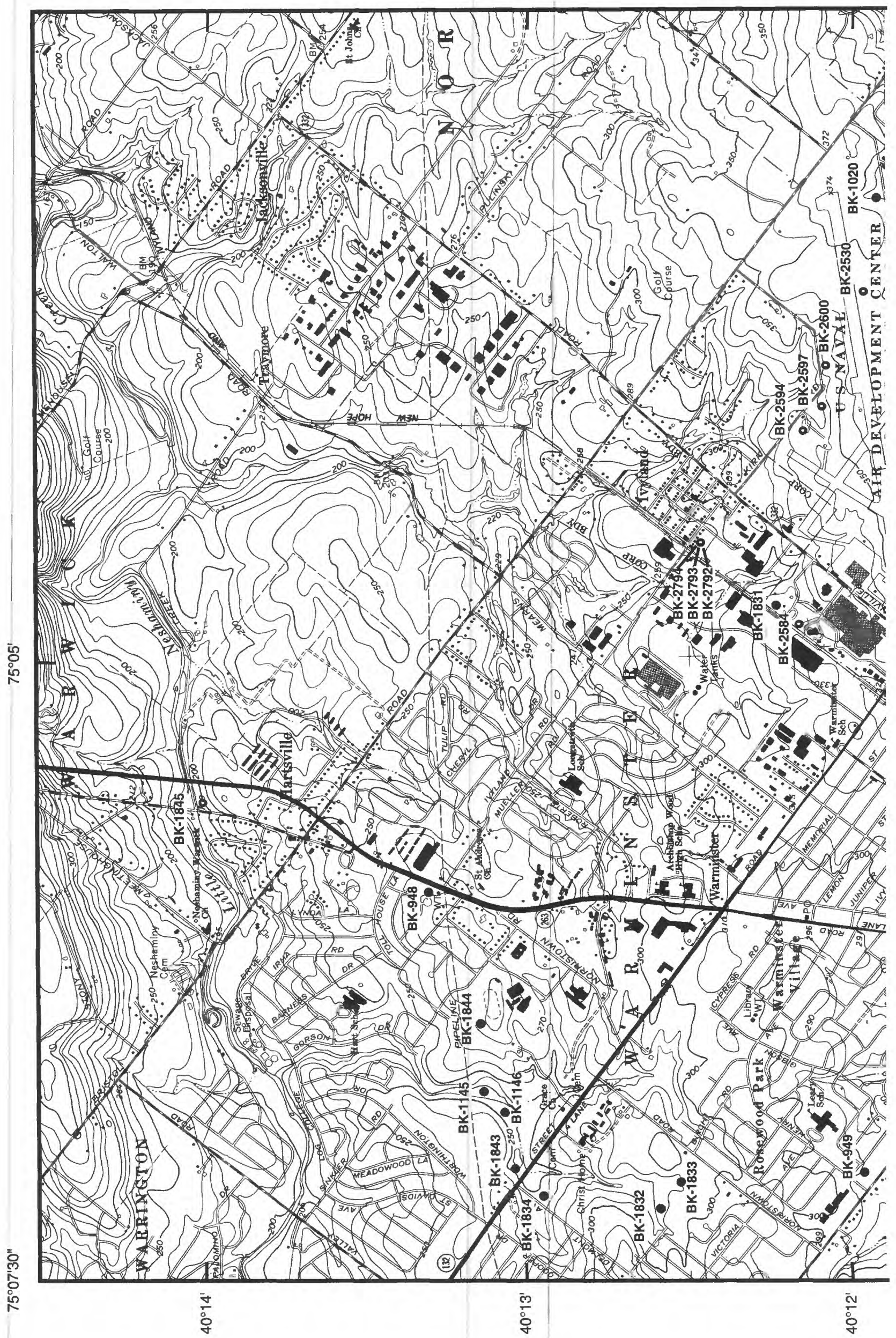




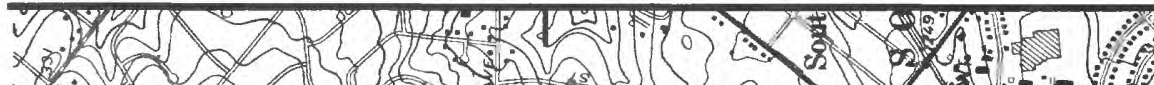

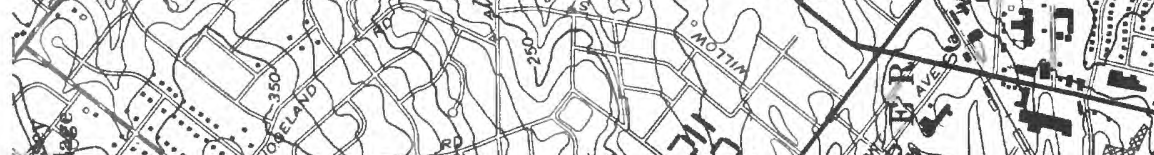

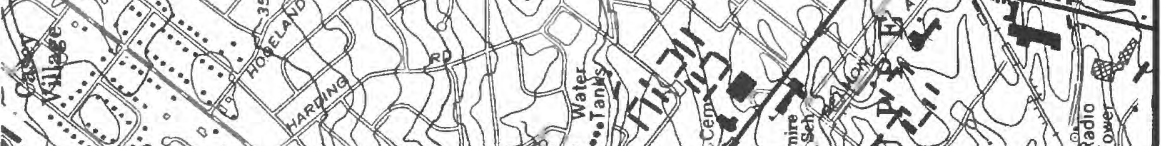
. n
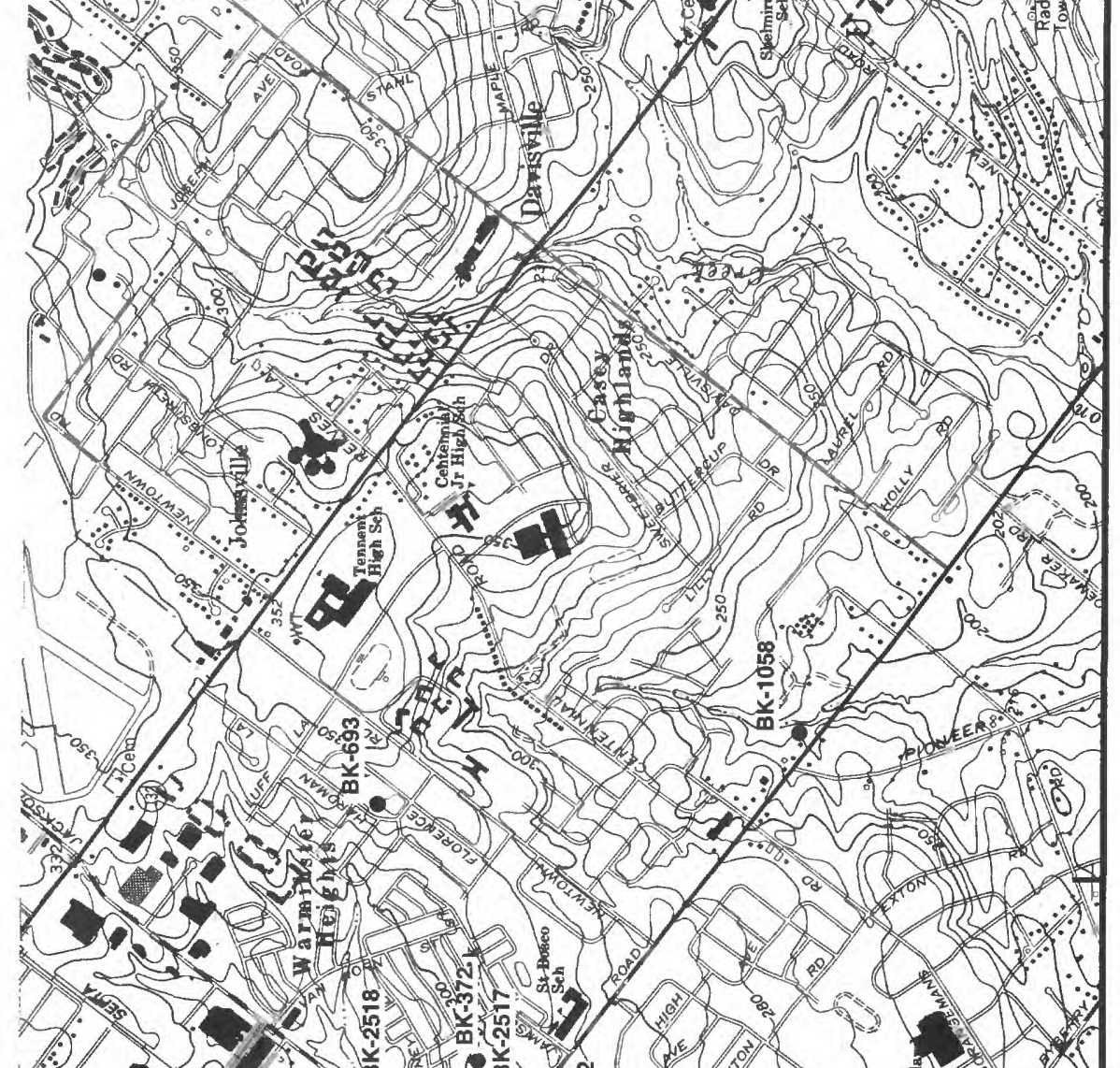

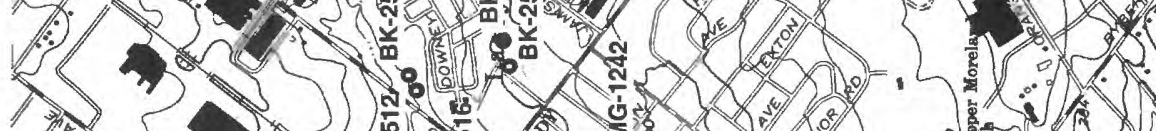
2 - 12 2y J a

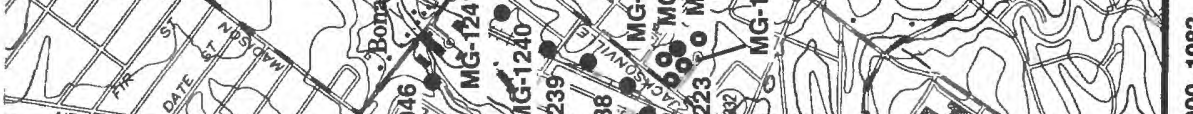

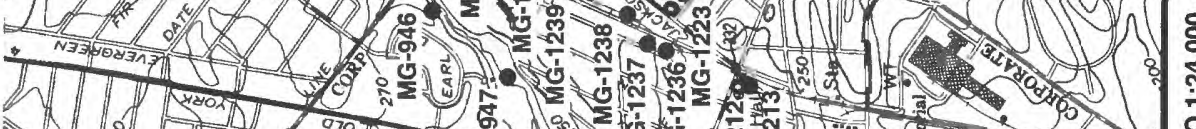

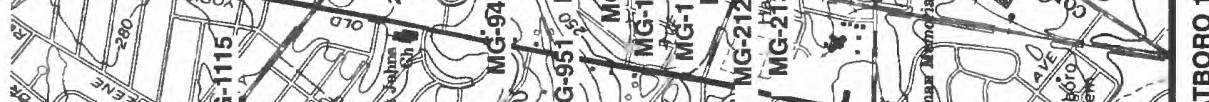
1. 10.10

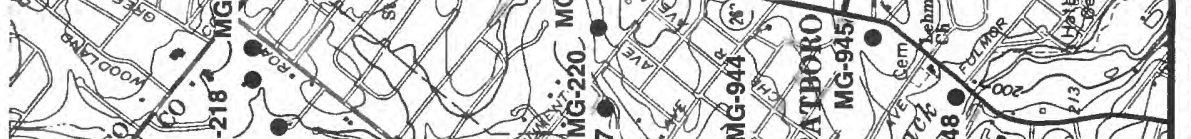

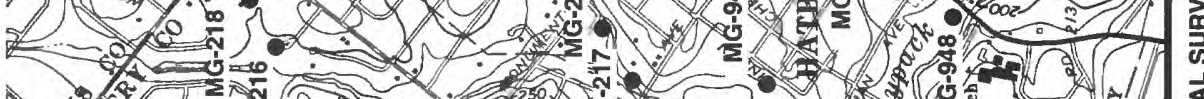
$1 \%$ \% (1)

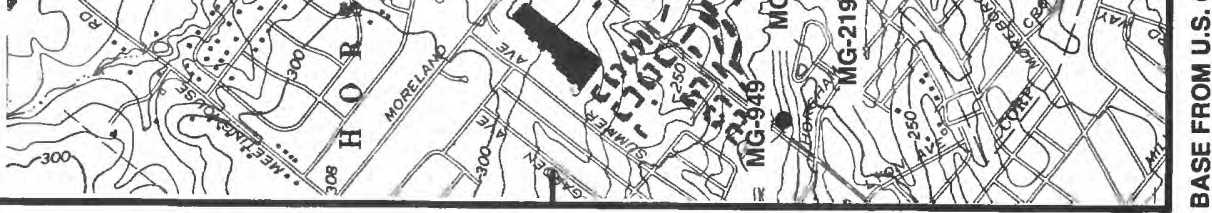

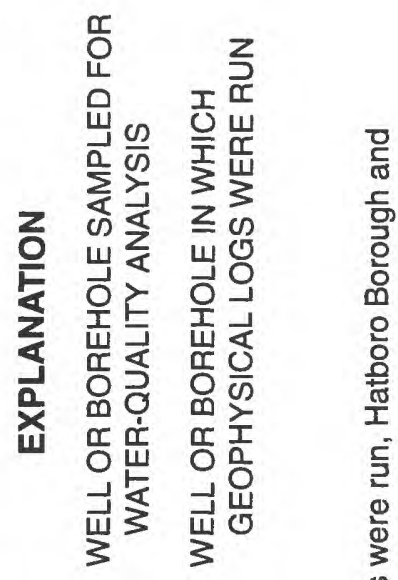

总

- $\circ$ 奇

$\frac{1}{2}$

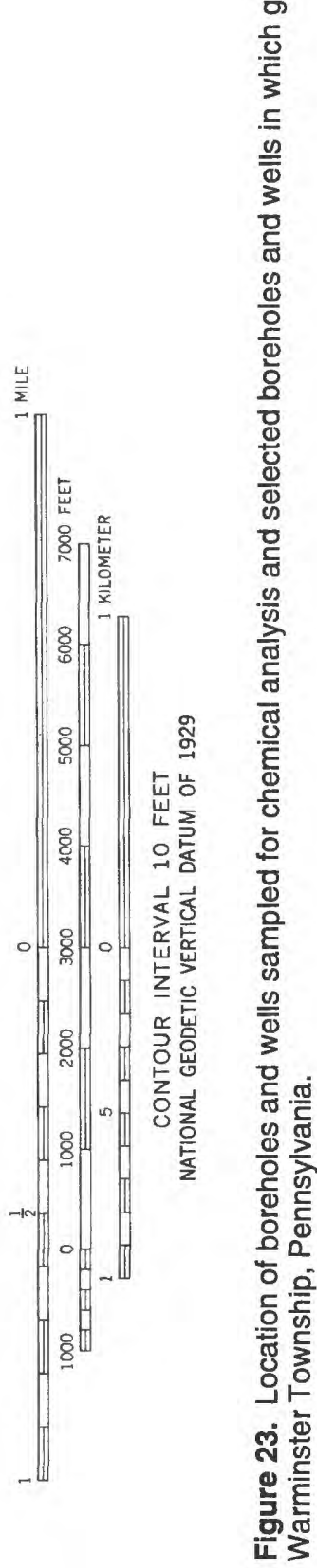


Table 3. Volatile organic compounds detected in ground water, Hatboro Borough and Warminster Township, Pennsylvania

[Concentrations in micrograms per liter]

\begin{tabular}{|c|c|c|}
\hline Compound & $\begin{array}{l}\text { Number of } \\
\text { wells in which } \\
\text { compound } \\
\text { was detected }\end{array}$ & $\begin{array}{l}\text { Maximum } \\
\text { concentration } \\
\text { detected }\end{array}$ \\
\hline Benzene & 2 & 0.5 \\
\hline Bromoform & 2 & 2.1 \\
\hline Carbon tetrachloride & 5 & 25 \\
\hline Chlorodibromomethane & 2 & 1.6 \\
\hline Chloroform & 28 & 15 \\
\hline Dichlorobromomethane & 4 & .6 \\
\hline Dichlorodifluoromethane & 1 & .2 \\
\hline 1,1-Dichloroethane & 11 & 14 \\
\hline 1,2-Dichloroethane & 2 & 5.6 \\
\hline 1,1-Dichloroethylene & 11 & 260 \\
\hline trans-1,2-Dichloroethylene ${ }^{1}$ & 17 & 72 \\
\hline 1,2-Dichloropropane & 2 & 60 \\
\hline Methylene chloride & 2 & .4 \\
\hline Tetrachloroethylene & 24 & 170 \\
\hline Toluene & 5 & 1.2 \\
\hline 1,1,1-Trichloroethane & 24 & 1,400 \\
\hline 1,1,2-Trichloroethane & 3 & .4 \\
\hline Trichloroethylene & 26 & 5,800 \\
\hline Trichlorofluoromethane & 3 & .9 \\
\hline Vinyl chloride & 3 & 1.4 \\
\hline
\end{tabular}

$1_{\text {trans-1,2-Dichloroethylene and cis-1,2-dichloroethylene reported }}$ as trans-1,2-dichloroethylene.

\section{CROSS-CONTAMINATION THROUGH OPEN BOREHOLES}

\section{Extent of Cross-Contamination}

In the industrial area of northern Hatboro along and to the west of Jacksonville Road, samples of borehole fluid moving in nine boreholes (fig. 24) were collected for laboratory analysis to quantify aquifer cross-contamination. None of the boreholes sampled were on an NPL site. After intervals of borehole flow were determined from the geophysical logs, a sample of the moving fluid was extracted with a nitrogen-driven bladder pump at a rate less than that of the measured borehole flow and was analyzed for VOC's. Downward flow was measured in all of the boreholes; the samples represent water moving from the shallow to the deeper part of the aquifer.

Water samples from all nine boreholes contained detectable concentrations of VOC's. TCE and PCE were detected in samples from all of the boreholes, and chloroform, TCA, and trans-1,2-DCE were detected in samples from eight of the nine boreholes. Concentrations of TCE, TCA, and 1,1-DCE as great as $5,800,1,400$, and $260 \mu \mathrm{g} / \mathrm{L}$, respectively, show that some water moving downward in the aquifer through these open boreholes is highly contaminated and that open boreholes may contribute substantially to the movement of ground-water contamination. Concentrations of VOC's detected in the borehole-flow samples are summarized in table 4. Because these water samples represent water moving through open boreholes from the shallow to the deeper part of the aquifer system, sample data can be used to show the extent of aquifer cross-contamination in this area.

The rate of borehole flow is known; therefore, concentrations of VOC's in the water samples can be used to estimate the downward mass flux and the extent of aquifer cross-contamination. The mass of each compound moving downward in the aquifer through an open borehole annually was estimated from the measured borehole-flow rate and results of chemical analysis of the fluid by

$$
\mathrm{M}=1.99 \mathrm{Q} \mathrm{C} \text {, }
$$

where

$\mathrm{M}$ is the quantity of a compound moving down a borehole annually, in grams per year;

$\mathrm{Q}$ is the measured borehole flow, in gallons per minute; and

$\mathrm{C}$ is the concentration of the compound in the borehole fluid, in micrograms per liter.

Because most of the boreholes were sampled once and concentrations of VOC's vary temporally, the mass flux estimates should be considered an approximation. The data can be used to provide an estimate of the amount of cross-contamination. 


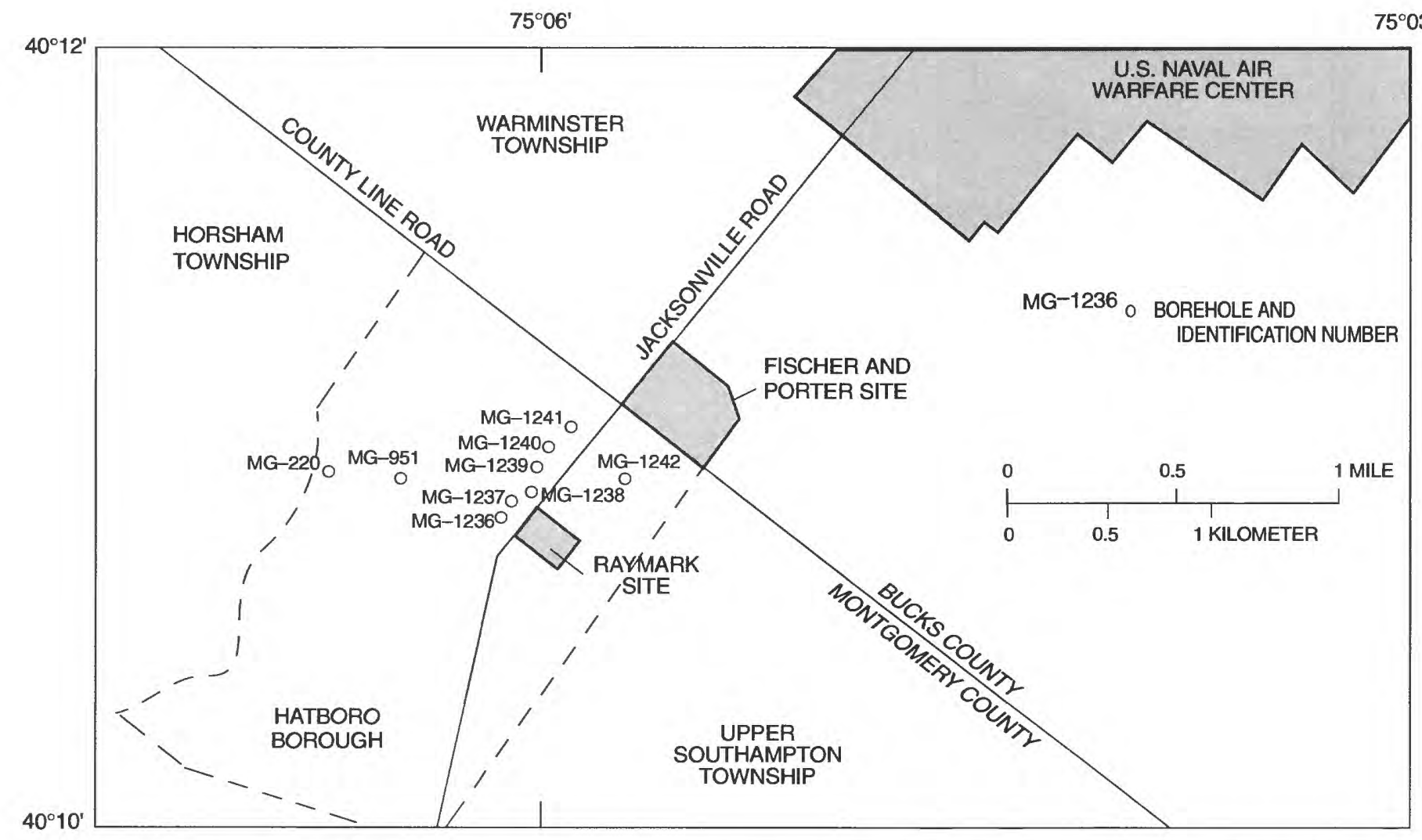

Figure 24. Boreholes sampled for volatile organic compounds in the Jacksonville Road area, Hatboro Borough, Pennsylvania.

An estimated $80.6 \mathrm{~kg} / \mathrm{yr}$ (14.7 gal/yr) of VOC's (table 5) were moving downward through the nine open boreholes sampled from the contaminated, upper part of the aquifer to the lower part. TCE accounted for 94 percent and TCA accounted for 3 percent of the compounds by mass.

Borehole MG 1239 is at the site of the former Roberts and Mander Stove Company, which manufactured gas kitchen ranges from the late 1800's to the early 1950's. The borehole is behind the former foundry building. Borehole-flow samples show concentrations of TCE and TCA as high as 5,800 and $1,400 \mu \mathrm{g} / \mathrm{L}$, respectively (table 9 ). The pumping of public supply well MG-947 (Hatboro-17), 1,100 ft downdip, causes a daily water-level change of approximately $3.3 \mathrm{ft}$ in borehole MG-1239, indicating a strong hydraulic connection. On the basis of borehole geophysical logs and borehole-flow measurements, water containing elevated concentrations of VOC's enters borehole MG-1239 between 50 and $60 \mathrm{ft}$ bls and moves downward at $0.7 \mathrm{gal} / \mathrm{min}$ to a fluid-receiving zone about $136 \mathrm{ft}$ bls. Water then moves through the deeper part of the aquifer to well MG-947.

In response to a verbal presentation of study results by the USGS in 1993, the USEPA Superfund Removal Branch plugged or reconstructed five of the sampled boreholes (MG-220, MG-951, MG-1238, MG-1239, and MG-1240). Boreholes MG-1236, MG-1237, MG-1241, and MG-1242 were reconstructed by the USGS so that they are now open only to a single water-bearing zone. The aquifer cross-contamination problem caused by known open boreholes in the Jacksonville Road area of Hatboro has been eliminated.

\section{Prevention of Ground-Water Cross-Contamination}

Borehole geophysical logs were used as a guide to design and construct monitor-well networks at all three NPL sites. Generally, a deep (150-350 ft) 
borehole was drilled at each monitor-well cluster site, and a suite of geophysical logs was run. Interpretation of geophysical logs enabled the identification of water-bearing zones that produce and receive water; these zones should not be connected. From the logs, discrete intervals to be monitored were selected.

The monitor-well network at the Raymark Site serves as an example of how geophysical logs were used as a guide to design and construct monitor wells that do not cause cross-contamination. The USEPA's investigation of the Raymark Site included the drilling and construction of nine monitor wells (three cluster locations with three wells in each cluster) and the reconstruction of an existing open borehole to eliminate cross-contamination.

Table 4. Volatile organic compounds detected in borehole-flow samples from nine sampled boreholes in the Jacksonville Road area, Hatboro Borough, Pennsylvania

[Concentrations in micrograms per liter]

\begin{tabular}{|c|c|c|}
\hline Compound & $\begin{array}{l}\text { Number of } \\
\text { boreholes } \\
\text { in which } \\
\text { compound } \\
\text { was detected }\end{array}$ & $\begin{array}{l}\text { Maximum } \\
\text { concentration } \\
\text { detected }\end{array}$ \\
\hline Benzene & 1 & 0.5 \\
\hline Bromoform & 1 & .4 \\
\hline Carbon tetrachloride & 4 & 25 \\
\hline Chlorodibromomethane & 1 & .2 \\
\hline Chloroform & 8 & 15 \\
\hline Dichlorobromomethane & 2 & .4 \\
\hline 1,1-Dichloroethane & 6 & 14 \\
\hline 1,2-Dichloroethane & 2 & 5.6 \\
\hline 1,1-Dichloroethylene & 6 & 260 \\
\hline trans-1,2-Dichloroethylene ${ }^{1}$ & 8 & 72 \\
\hline 1,2-Dichloropropane & 2 & 60 \\
\hline Methylene chloride & 2 & .4 \\
\hline Tetrachloroethylene & 9 & 57 \\
\hline Toluene & 1 & .2 \\
\hline 1,1,1-Trichloroethane & 8 & 1,400 \\
\hline 1,1,2-Trichloroethane & 2 & .4 \\
\hline Trichloroethylene & 9 & 5,800 \\
\hline Trichlorofluoromethane & 1 & .9 \\
\hline Vinyl chloride & 2 & 1.4 \\
\hline
\end{tabular}

${ }^{1}$ trans-1,2-dichloroethylene and cis-1,2-dichloroethylene reported as trans-1,2-dichloroethylene.
Table 5. Estimated quantity of volatile organic compounds moving downward in the Stockton Formation through nine sampled boreholes in the Jacksonville Road area, Hatboro Borough, Pennsylvania

\begin{tabular}{l|c}
\hline Compound & $\begin{array}{c}\text { Quantity moving } \\
\text { downward in the } \\
\text { aquifer through } \\
\text { open boreholes } \\
\text { (grams per year) }\end{array}$ \\
\hline Carbon tetrachloride & 570 \\
1,1-Dichloroethane & 200 \\
1,2-Dichloroethane & 8 \\
Chloroform & 36 \\
1,1-Dichloroethylene & 730 \\
trans-1,2-Dichloroethylene & 250 \\
1,2-Dichloropropane & 450 \\
Tetrachloroethylene & 450 \\
1,1,1-Trichloroethane & 2,050 \\
1,1,2-Trichloroethane & 1 \\
Trichloroethylene & 75,860 \\
Total & 80,600 \\
\hline
\end{tabular}

1trans-1,2-dichloroethylene and cis-1,2-dichloroethylene reported as trans-1,2-dichloroethylene.

Before drilling, an existing open-hole monitor well (MG-1114) was logged to determine hydrogeological conditions at the site. Borehole-flow measurements made in borehole MG-1114 showed that water moved downward from shallow to deep water-bearing zones under nonpumping conditions (fig. 25). Slugs of high-conductance fluid injected at 75,100, and $140 \mathrm{ft}$ bls moved downward at rates of $0.5,5.7$, and less than $0.5 \mathrm{gal} / \mathrm{min}$, respectively. The caliper, fluidtemperature, and fluid-resistivity geophysical logs and borehole-flow measurements showed that water enters the borehole at a rate of $0.5 \mathrm{gal} / \mathrm{min}$ through fractures at 57 and $71 \mathrm{ft} \mathrm{bls} \mathrm{and} \mathrm{moves} \mathrm{downward.} \mathrm{An} \mathrm{addi-}$ tional $5.2 \mathrm{gal} / \mathrm{min}$ of water enters the borehole through a fracture at $81 \mathrm{ft}$ bls and flows downward. Water exits the borehole through fractures at 131-135 and 142-144 ft bls.

The caliper log was used to determine smooth sections of borehole MG-1114 to set straddle packers and intervals to isolate for discrete-zone sampling for VOC's. The concentrations of TCE in water from the interval isolated above $75 \mathrm{ft}$ bls was $11,000 \mu \mathrm{g} / \mathrm{L}$, the concentration of TCE in water from the interval isolated between 75 and $95 \mathrm{ft}$ bls was $530 \mu \mathrm{g} / \mathrm{L}$, 


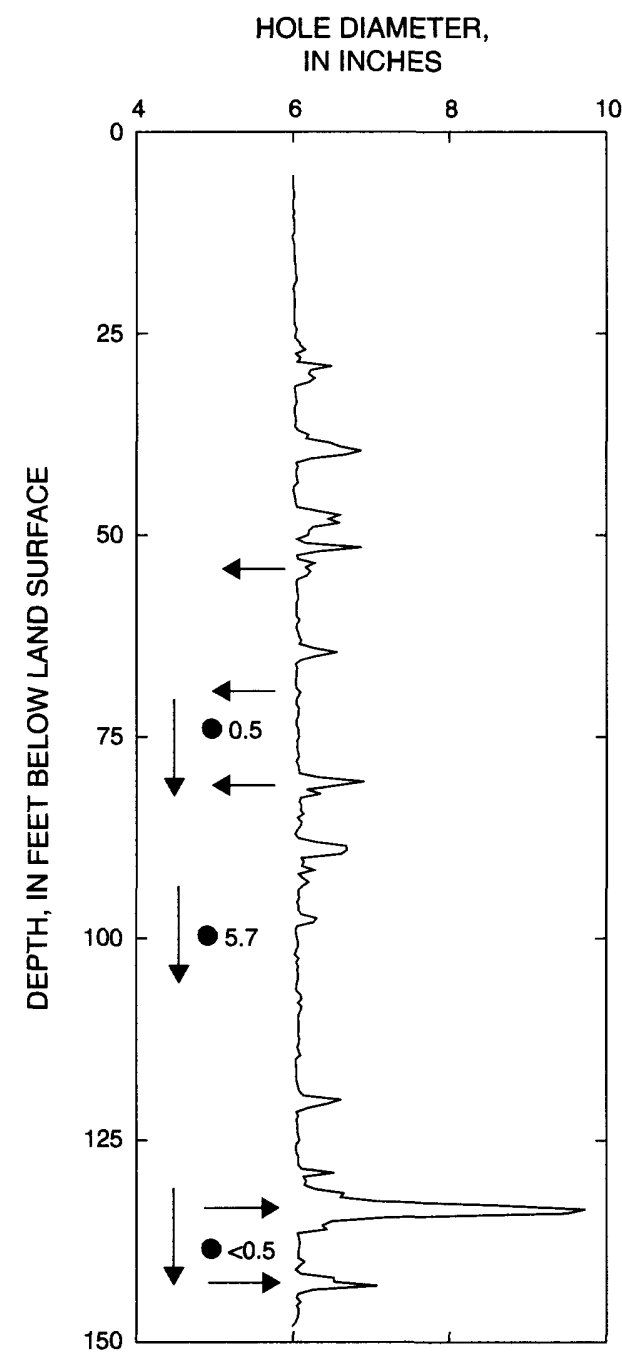

FLUID TEMPERATURE,

FLUID RESISTIVITY,

IN DEGREES CELSIUS

IN OHM-METERS
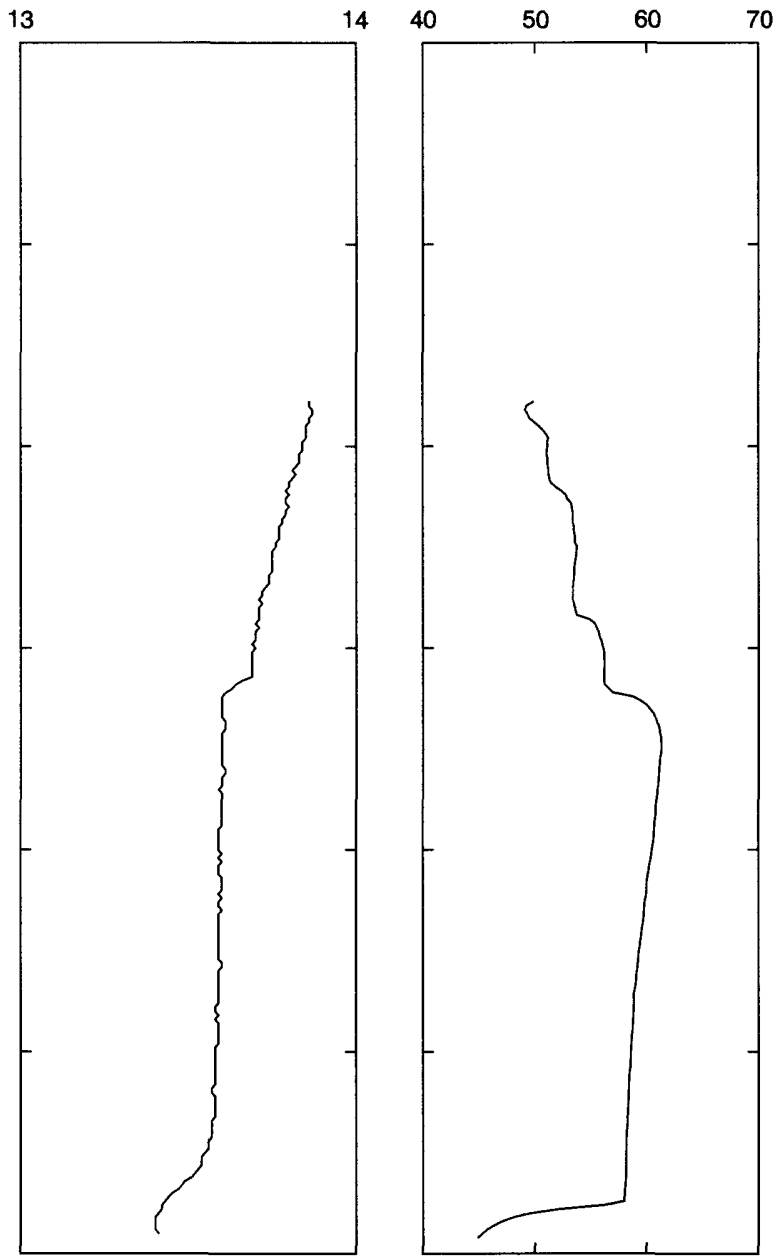

\section{EXPLANATION}

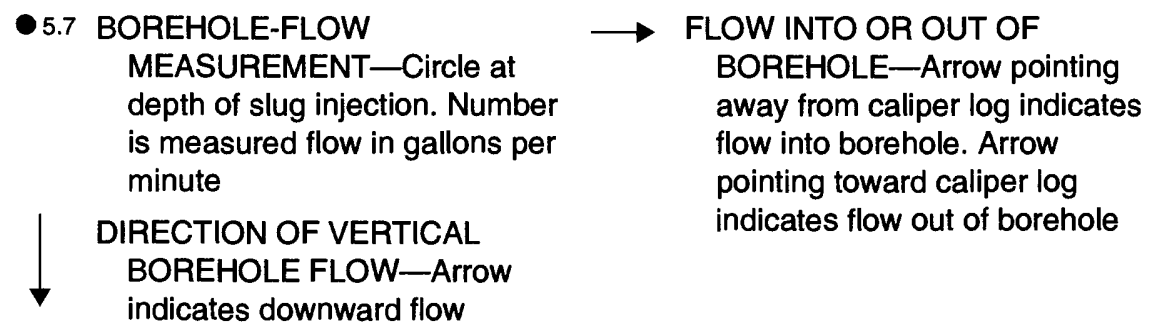

Figure 25. Caliper, fluid-temperature, and fluid-resistivity logs from borehole MG-1114, Hatboro Borough, Pennsylvania, showing borehole-flow measurements. 
and the concentrations of TCE in water from the interval isolated between 125 and $148 \mathrm{ft}$ bls was $1,100 \mu \mathrm{g} / \mathrm{L}$. On the basis of the chemical, geophysical, and borehole-flow measurement data, water $(0.5 \mathrm{gal} / \mathrm{min})$ with elevated concentrations of TCE $(11,000 \mu \mathrm{g} / \mathrm{L})$ entered the borehole through fractures at 57 and $71 \mathrm{ft}$ bls and moved downward. It was diluted by water $(5.2 \mathrm{gal} / \mathrm{min})$ with a much lower concentration of TCE $(530 \mu \mathrm{g} / \mathrm{L})$ that entered the borehole through the fracture at $81 \mathrm{ft} \mathrm{bls,}$ and it was further diluted to a concentration of $1,100 \mu \mathrm{g} / \mathrm{L}$ by water in the water-receiving zone. Borehole MG-1114 was constructed as a monitor well open from 138 to $148 \mathrm{ft}$ bls, thus eliminating the cross-connection between the shallow, contaminated water-producing zones and the deeper waterreceiving zones. The water level in the deep-screened zone of well MG-1114 responds in the same way that the water level in deep-screened monitor well MG-1222 (fig. 14) responds to the pumping of public supply well MG-944 (Hatboro-14).

The construction of a cluster of three monitor wells at the location of 200-ft-deep borehole MG-1222 shows how geophysical logs (fig. 26) were used to design and construct a well cluster to monitor multiple discrete intervals in the aquifer and to avoid a cross-connection among the monitored intervals. The caliper log shows that the major fractures in borehole MG-1222 are at 24, 43-44, 56, 83-86, 90-92, 121, 123, 128, and 131-132 ft bls. The fluid-resistivity $\log$ shows sharp decreases in fluid resistance at $83,128,146$, and $189 \mathrm{ft}$ bls, indicating water-producing or water-receiving zones. The fluidtemperature log shows intervals of nearly constant temperature at depths of about 74-80, 80-130, and 130-192 ft bls. Slugs of high-conductance fluid injected at 80,95 , and $170 \mathrm{ft}$ bls moved downward at rates of $2.3,2.6$, and $3.5 \mathrm{gal} / \mathrm{min}$, respectively. The geophysical logs and borehole-flow measurements show that water-producing fractures from 56 to $63 \mathrm{ft}$ bls in a silty, fine-grained sandstone unit produce $2.3 \mathrm{gal} / \mathrm{min}$ of water under nonpumping conditions. An additional $0.3 \mathrm{gal} / \mathrm{min}$ of water enters the borehole from a water-producing fracture in the same unit at $82-86 \mathrm{ft}$ bls. An additional $0.9 \mathrm{gal} / \mathrm{min}$ of water enters the borehole from a water-producing fracture in a fine-grained sandstone unit at 130-132 and $144 \mathrm{ft}$ bls.
Water exits the borehole through a water-receiving fracture in a medium- to coarse-grained sandstone unit at $189 \mathrm{ft}$ bls. Borehole flow does not occur below $189 \mathrm{ft}$ bls.

The 200-ft-deep borehole was reconstructed as a monitor well open from 185 to $195 \mathrm{ft}$ bls to monitor the fluid-receiving zone at $188 \mathrm{ft}$ bls. Two additional monitor wells open to a shallow and an intermediate-depth zone were constructed next to the deep well. The monitor well open to the intermediate interval (118-138 ft bls) monitors the fluid-producing zone at $128 \mathrm{ft}$ bls. The monitor well open to the shallow interval (33-63 ft bls) monitors the upper, unconfined part of the aquifer system, which includes the fluid-producing zones at $56-63 \mathrm{ft}$ bls. Three monitor wells in the cluster monitor the major waterproducing and water-receiving zones above $200 \mathrm{ft}$ bls without allowing a cross-connection between these zones (fig. 13).

In the Stockton Formation, depth of waterbearing zones in an area cannot be determined from one borehole. Each borehole should be logged and evaluated separately. The same water-bearing zone may not be intersected in adjacent boreholes, especially if it is a vertical fracture with a different orientation than that of the adjacent boreholes. The caliper and natural-gamma logs of three adjacent boreholes drilled about $15 \mathrm{ft}$ from each other are shown in figure 27. Despite their closeness, each borehole penetrates different water-bearing zones in different beds. Lithology is generalized and is correlated from the natural-gamma logs. Borehole BK-2793 penetrated a water-bearing fracture in bed $\mathrm{C}$ at $72 \mathrm{ft}$ bls; the other two boreholes did not penetrate a water-bearing fracture in bed C (fig. 27). Borehole BK-2794 penetrated water-bearing fractures in bed $E$ at $111 \mathrm{ft}$ bls and in bed $\mathrm{G}$ at $164-170 \mathrm{ft}$ bls (fig. 27); the driller reported a water-bearing zone at $215 \mathrm{ft}$ bls, but the caliper log does not show a fracture, and heat-pulse-flowmeter measurements did not indicate a water-bearing fracture at that depth. Borehole BK-2792, drilled to the same depth as borehole BK-2794, penetrated only one water-bearing fracture in bed $\mathrm{L}$ at $224 \mathrm{ft}$ bls (fig. 27); heat-pulse-flowmeter measurements showed upward flow from this fracture under nonpumping conditions. 


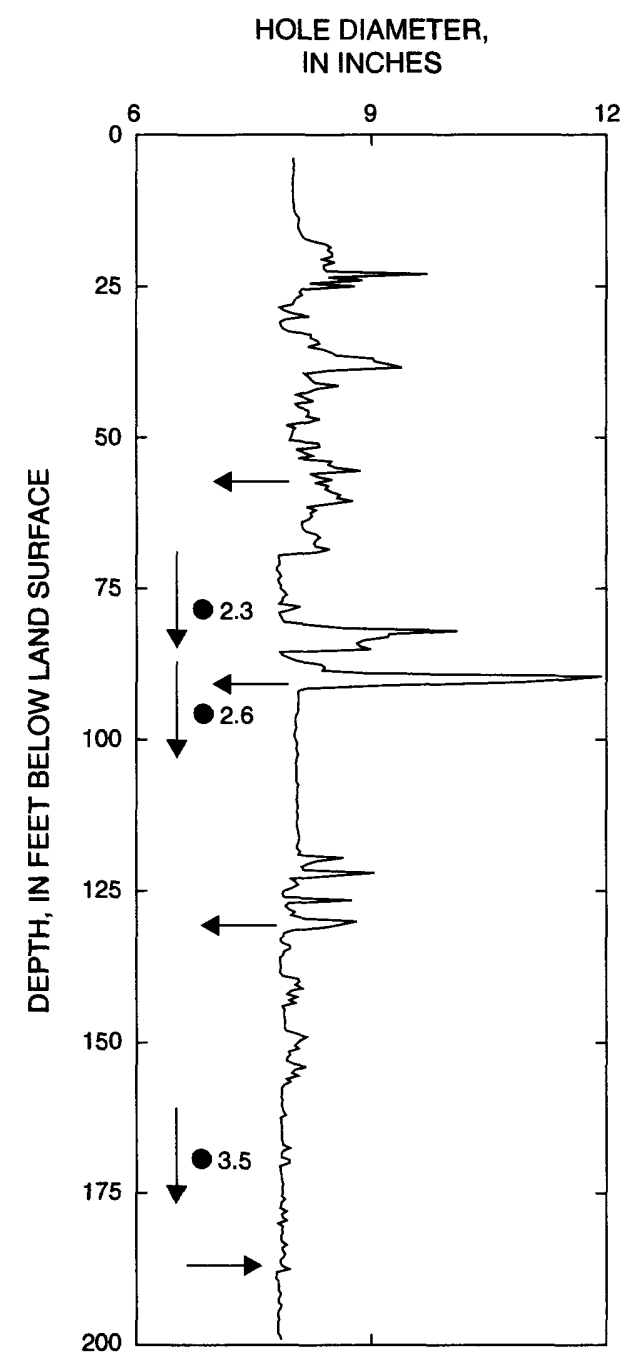

FLUID TEMPERATURE,

FLUID RESISTIVITY, IN DEGREES CELSIUS IN OHM-METERS

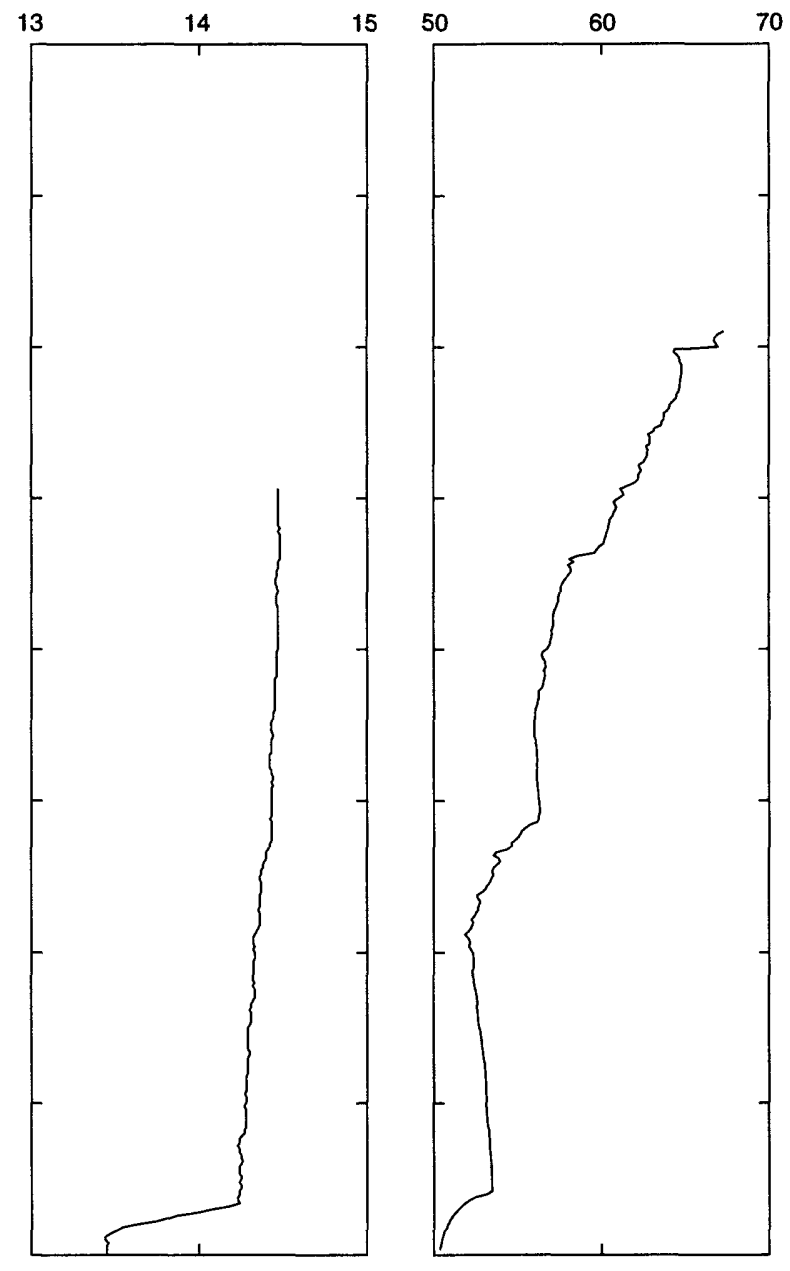

\section{EXPLANATION}

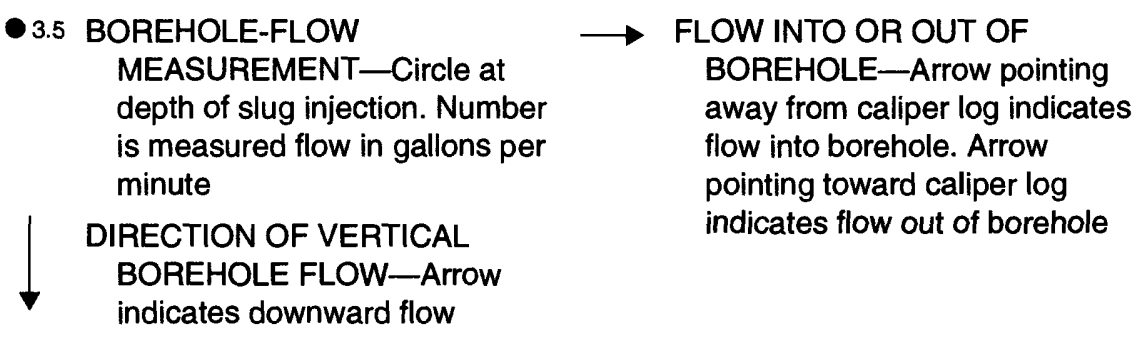

Figure 26. Caliper, fluid-temperature, and fluid-resistivity logs from borehole MG-1222, Hatboro Borough, Pennsylvania, showing borehole-flow measurements. 


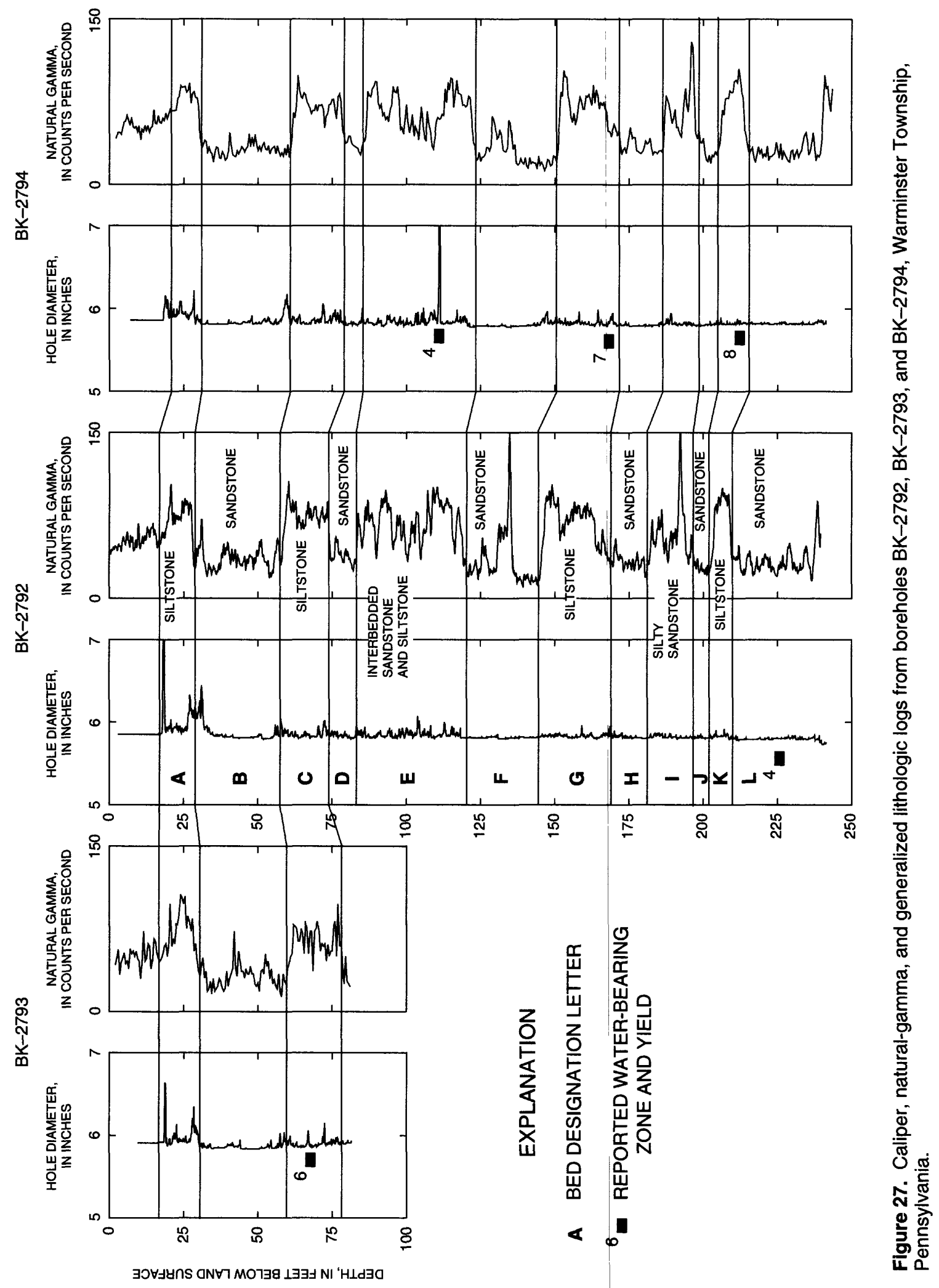




\section{SUMMARY AND CONCLUSIONS}

The study area is a 9- $\mathrm{mi}^{2}$ area in Hatboro Borough, Montgomery County, and Warminster Township, Bucks County, Pa., underlain by sedimentary rocks of the Stockton Formation of Upper Triassic age. Rocks that underlie the study area belong to the middle arkose member of the Stockton Formation; some deep boreholes may penetrate the lower arkose member. In the Hatboro area, the Stockton Formation strikes approximately N. $65^{\circ} \mathrm{E}$. and dips approximately $9^{\circ} \mathrm{NW}$. The rocks are chiefly arkosic sandstone and siltstone. The Stockton Formation includes alluvial fans, fluvial and lacustrine sandstones, and fluvial and near-shore lacustrine siltstones. From visual identification of five rock cores collected in the study area, eight lithologies were identified:

1. Siltstone, reddish-brown or dark purple-gray, sometimes micaceous.

2. Sandstone, pinkish-gray, silty, fine-grained.

3. Sandstone, dark-gray, very fine-grained.

4. Sandstone, gray, fine-grained.

5. Sandstone, gray, poorly sorted, fine- to mediumgrained.

6. Sandstone, gray, medium-grained.

7. Sandstone, light-gray, medium- to coarse-grained.

8. Conglomerate, light-gray or brown.

Rocks of the Stockton Formation form a complex, heterogeneous, multiaquifer system consisting of a series of gently dipping lithologic units with different hydraulic properties. The beds, a few inches to a few feet thick, act as a series of alternating aquifers and confining or semiconfining units that form a leaky, multiaquifer system. Most ground water in the unweathered zone moves through a network of interconnecting secondary openings-fractures, bedding planes, and joints. Beds within the Stockton Formation are hydraulically connected by vertical joints that cross each other at various angles throughout the beds; therefore, ground water may move across beds, particularly in the direction of dip, rather than through individual beds. Primary porosity that may have originally existed has been almost eliminated by compaction and cementation. Overall, the sandstone units are the principle water-bearing units, but some finer grained units may contain waterbearing zones. Ground water is unconfined in the shallower part of the aquifer and semiconfined or confined in the deeper part of the aquifer. Ground water is confined by overlying, less permeable lithologic units. Differences in the ratio of vertical to horizontal hydraulic conductivity and differences in vertical hydraulic conductivity within and among lithologic units create confining conditions.

Nearly all deep wells in the Stockton Formation are open to several water-bearing zones and are multiaquifer wells. Each water-bearing zone usually has a different hydraulic head. The hydraulic head in a deep, open-hole well is the composite of the heads in the several water-bearing zones penetrated. Where differences in hydraulic head exist between waterbearing zones, water in the well bore flows under nonpumping conditions in the direction of decreasing head. In the Hatboro area, water moves downward through the aquifer system in response to a downward head gradient, which is caused in part by the pumping of deep public supply wells.

Determination of the potential for borehole flow was based on caliper, natural-gamma, single-pointresistance, fluid-resistivity, and (or) fluid-temperature logs that were run in 162 boreholes 31 to $655 \mathrm{ft}$ deep. Upon completion of geophysical logging, the suite of logs was evaluated in the field to determine the potential for borehole flow and to choose zones of potential borehole flow. Direction and rate of borehole-fluid movement were determined in 83 wells by the brinetracing method; the lower limit of flow measurement is about $0.5 \mathrm{gal} / \mathrm{min}$ in a 6 -in.-diameter borehole. The rate and direction of borehole-fluid movement were determined in 10 boreholes by use of a heat-pulse flowmeter; the range of flow measurement is 0.01 to $1 \mathrm{gal} / \mathrm{min}$.

The potential is great for borehole flow and cross-contamination in open-hole boreholes in the Stockton Formation. Borehole flow was measurable in 65 of 93 boreholes (70 percent). No flow was measurable in 19 boreholes. The direction and rate of borehole flow was not determinable for nine boreholes by use of the brine-tracing method. Fluid movement at rates up to $17 \mathrm{gal} / \mathrm{min}$ was measured. Downward flow was measured in 36 boreholes, not including those boreholes in which two directions of flow were measured. The predominant direction of vertical borehole flow measured in Hatboro Borough and in Warminster Township near the Fischer and Porter Site is downward. Upward vertical flow was measured in 23 boreholes. Many of these boreholes are just northwest of the surface-water divide 
between the Pennypack and Little Neshaminy Creek drainage basins. The divide parallels the strike of the Stockton Formation, and boreholes to the northwest of the divide penetrate beds that crop out in updip, upgradient areas.

Fluid movement under nonpumping conditions in some boreholes may be very complex. Both upward and downward vertical flow was measured in six boreholes. These boreholes ranged from 396 to $470 \mathrm{ft}$ deep and were among the deepest boreholes logged. Fluid movement was upward in the upper part of the borehole and downward in the lower part of the borehole in two boreholes. Fluid movement was downward in the upper part of the borehole and upward in the lower part of the borehole in three boreholes.

Ground-water contamination by VOC's is widespread in the study area. Detectable concentrations of VOC's were present in water samples from all 24 wells sampled in Hatboro Borough and in water samples from 10 of 14 wells ( 71 percent) sampled in Warminster Township. However, concentrations of VOC's in many water samples did not exceed the USEPA maximum contaminant levels. Chloroform was the most commonly detected VOC ( 28 wells or 74 percent of wells sampled), followed by TCE (26 wells or 68 percent), and PCE and TCA (24 wells or 63 percent).

To estimate the quantity of VOC's in borehole flow, samples of borehole flow from nine boreholes in the industrial area of Hatboro along and to the west of Jacksonville Road were collected for laboratory analysis. None of the boreholes sampled were on an NPL site, but they were near the Raymark NPL site and the site of the former Roberts and Mander Stove Company. Downward flow was measured in all of the boreholes; the samples represent water moving from the contaminated, shallow part of the aquifer to the deeper part of the aquifer, which is tapped by public supply wells. Water samples from all nine boreholes contained detectable concentrations of VOC's. Concentrations of TCE, TCA, and 1,1-DCE as great as $5,800,1,400$, and $260 \mu \mathrm{g} / \mathrm{L}$, respectively, show that some water moving downward in the aquifer through these open boreholes is highly contaminated and that open boreholes may contribute substantially to movement of ground-water contamination. An estimated $80.6 \mathrm{~kg} / \mathrm{yr}$ (14.7 gal/yr) of VOC's was moving downward through the nine open boreholes sampled from the contaminated, upper part of the aquifer to the lower part. TCE accounted for 94 percent and TCA accounted for 3 percent of the compounds by mass.

Borehole geophysical logs were used as a guide to design and construct monitor-well networks at three NPL sites. An open borehole was drilled, and a suite of geophysical logs was run. Interpretation of geophysical logs enabled the identification of waterbearing zones that produce and receive water; these are zones that should not be connected. From the geophysical logs, discrete intervals to be monitored were selected. In the Stockton Formation, the same water-bearing zone may not be intersected in adjacent boreholes, especially if it is a vertical fracture with a different orientation than that of the adjacent boreholes. In most areas of the Stockton Formation, depth of water-bearing zones in an area cannot be determined from one borehole. Each borehole should be logged and evaluated separately.

A combination of borehole geophysical methods, measurements of vertical borehole flow, and analyses of borehole-fluid samples provided effective methods to identify and assess an aquifer cross-contamination problem. Borehole geophysical methods were used to identify zones of fluid movement. Borehole-flow measurements provided data on the direction and rate of borehole-fluid movement. Sampling and analysis of moving borehole fluid provided concentrations of VOC's that enable estimations of quantities of VOC's moving through sampled open boreholes.

\section{REFERENCES CITED}

Freedman, D.L., and Gossett, J.M., 1989, Biological reductive dechlorination of tetrachloroethylene and trichloroethylene to ethylene under methanogenic conditions: Applied and Environmental Microbiology, v. 55, p. $2144-2151$.

Glaeser, J.D., 1966, Provenance, dispersal, and depositional environments of Triassic sediments in the NewarkGettysburg basin: Pennsylvania Geological Survey, 4th ser., Bulletin G43, 170 p.

Haliburton NUS Environmental Corporation, 1992, Phase II remedial investigation report volume 1 Naval Air Warfare Center (NAWC) Warminster, Pennsylvania: Wayne, Pa. [variously paged].

Keys, W.S., 1990, Borehole geophysics applied to groundwater investigations: U.S. Geological Survey Techniques of Water-Resources Investigations, book 2, chap. E-2, 149 p. 
Kharaka, Y.K., Gunter, W.D., Aggarwal, P.K., Perkins, E.H., and DeBraal, J.D., 1988, SOLMINEQ.88A computer program for modeling of water-rock interactions: U.S. Geological Survey WaterResources Investigations Report 88-4227, 420 p.

Olsen, H.W., Gill, J.D., Willden, A.T., and Nelson, K.R., 1991, Innovations in hydraulic conductivity measurements: Geotechnical Engineering 1991, Transportation Research Record 1309, Transportation Research Board, National Research Council, p. 9-17.

Parsons, Frances, Lange, G.B., and Rice, Ramona, 1985, Biotransformation of chlorinated organic solvents in static microcosms: Environmental Toxicology and Chemistry, v. 4, p. 739-742.

Patten, E.P., Jr., and Bennett, G.D., 1962, Methods of flow measurement in well bores: U.S. Geological Survey Water-Supply Paper 1544-C, 28 p.

Rima, D.R., Meisler, Harold, and Longwill, Stanley, 1962, Geology and hydrology of the Stockton Formation in southeastern Pennsylvania: Pennsylvania Geological Survey, 4th ser., Water Resources Report 14, 111 p.

Sloto, R.A., and Davis, D.K., 1983, Effect of urbanization on the water resources of Warminster Township, Bucks County, Pennsylvania: U.S. Geological Survey Water-Resources Investigations Report 82-4020, $72 \mathrm{p}$.

Sloto, R.A., Macchiaroli, Paola, and Conger, R.W., 1996, Hydrology, geology, and vertical distribution of volatile organic compounds in ground water, Fischer and Porter Company Superfund Site, Warminster, Pennsylvania: U.S. Geological Survey WaterResources Investigations Report 95-4220, 169 p.
Sloto, R.A., Macchiaroli, Paola, and Towle, M.T., 1992, Identification of a multiaquifer ground-water crosscontamination problem in the Stockton Formation by use of borehole geophysical methods, Hatboro, Pennsylvania: Proceedings, Symposium on the Application of Geophysics to Engineering and Environmental Problems, Oakbrook, Illinois, April 26-29, 1992, Society of Engineering and Mineral Exploration Geophysicists, p. 21-35.

Sloto, R.A., and Schreffler, C.L., 1994, Hydrology and ground-water quality of northern Bucks County, Pennsylvania: U.S. Geological Survey WaterResources Investigations Report 94-4109, 85 p.

Tompkins, E.A., 1975, Soil survey of Bucks and Philadelphia Counties, Pennsylvania: U.S. Soil Conservation Service, $130 \mathrm{p}$.

Turner-Peterson, C.E., and Smoot, J.P., 1985, New thoughts on facies relationships in the Triassic Stockton and Lockatong Formations, Pennsylvania and New Jersey: U.S. Geological Survey Circular 946, p. 10-17.

U.S. Environmental Protection Agency, 1992, Superfund-Progress at National Priority List sites Pennsylvania 1992 update: U.S. Environmental Protection Agency Report 9200.5-738B, $242 \mathrm{p}$.

Vogel, T.M., and McCarty, P.L., 1985, Biotransformation of tetrachloroethylene to trichloroethylene, dichloroethylene, vinyl chloride, and carbon dioxide under methanogenic conditions: Applied and Environmental Microbiology, v. 49, p. 1080-1083. 
Table 6. Record of wells

[Latitude and longitude are given in degrees, minutes, and seconds. Casing length: first number is inner casing, second number is outer casing Casing diameter: first number is inner casing, second number is outer casing. Use of site: $\mathrm{Z}$, destroyed; $\mathrm{P}$, public supply; $\mathrm{U}$, unused; $\mathrm{O}$, observation or monitor well; --, no data]

\begin{tabular}{|c|c|c|c|c|c|c|c|c|c|}
\hline $\begin{array}{c}\text { Well } \\
\text { identification } \\
\text { number }\end{array}$ & Latitude & Longltude & $\begin{array}{l}\text { Owner or } \\
\text { site iocation }\end{array}$ & $\begin{array}{l}\text { Year } \\
\text { drilled }\end{array}$ & $\begin{array}{l}\text { Depth } \\
\text { drilled } \\
\text { (feet) }\end{array}$ & $\begin{array}{l}\text { Dlameter } \\
\text { (inches) }\end{array}$ & $\begin{array}{l}\text { Casing } \\
\text { length } \\
\text { (feet) }\end{array}$ & $\begin{array}{c}\text { Casing } \\
\text { dlameter } \\
\text { (Inches) }\end{array}$ & $\begin{array}{l}\text { Use } \\
\text { of } \\
\text { site }\end{array}$ \\
\hline \multicolumn{10}{|c|}{ Bucks County } \\
\hline BK-372 & 401059 & 0750523 & Fischer \& Porter Company & 1952 & 600 & 8 & 50 & 8 & $\mathrm{Z}$ \\
\hline BK-693 & 401116 & 0750450 & Warminster Municipal Authority & 1955 & 324 & 10 & $50 / 40$ & $10 / 14$ & $\mathbf{P}$ \\
\hline BK-948 & 401308 & 0750509 & Warminster Municipal Authority & 1963 & 516 & 10 & $88 / 50$ & $10 / 14$ & $\mathbf{P}$ \\
\hline BK-949 & 401158 & 0750704 & Warminster Municipal Authority & 1962 & 466 & 10 & $80 / 50$ & $10 / 14$ & $\mathbf{U}$ \\
\hline BK-1020 & 401155 & 0750307 & U.S. Naval Air Warfare Center & 1968 & 400 & 6 & $57 / 52$ & $10 / 14$ & $\mathrm{O}$ \\
\hline BK-1058 & 401030 & 0750440 & Warminster Municipal Authority & -- & 500 & 8 & 58 & 8 & $\mathbf{U}$ \\
\hline BK-1145 & 401308 & 0750644 & Warminster Municipal Authority & 1980 & 350 & 6 & 20 & 6 & $\mathbf{U}$ \\
\hline BK-1146 & 401304 & 0750649 & Warminster Municipal Authority & 1981 & 460 & 12 & $132 / 20$ & $12 / 20$ & $\mathbf{P}$ \\
\hline BK-1831 & 401215 & 0750445 & U.S. Naval Air Warfare Center & 1980 & 300 & 6 & 59 & 6 & $\mathrm{O}$ \\
\hline BK-1832 & 401235 & 0750711 & Warminster Municipal Authority & 1991 & 393 & 6 & 38 & 6 & $\mathrm{U}$ \\
\hline BK-1833 & 401232 & 0750706 & Warminster Municipal Authority & 1991 & 400 & 6 & 37 & 6 & $\mathbf{U}$ \\
\hline BK-1834 & 401247 & 0750709 & Warminster Municipal Authority & 1991 & 360 & 6 & 39 & 6 & $\mathbf{U}$ \\
\hline BK-1843 & 401301 & 0750703 & Warminster Municipal Authority & 1985 & 325 & 6 & 20 & 6 & $\mathbf{U}$ \\
\hline BK-1844 & 401308 & 0750630 & Warminster Municipal Authority & 1985 & 514 & 6 & 20 & 6 & $\mathbf{U}$ \\
\hline BK-1845 & 401403 & 0750505 & Warminster Municipal Authority & 1991 & 421 & 10 & 60 & 10 & $\mathbf{U}$ \\
\hline BK -2512 & 401115 & 0750531 & Fischer \& Porter Company & 1993 & 303 & 8 & $87 / 5$ & $8 / 12$ & $\mathrm{O}$ \\
\hline BK-2516 & 401107 & 0750541 & Fischer \& Porter Company & 1993 & 262 & 2 & 14 & 4 & $\mathrm{Z}$ \\
\hline BK-2517 & 401107 & 0750526 & Fischer \& Porter Company & 1993 & 277 & 2 & 20 & 4 & $\mathrm{Z}$ \\
\hline BK-2518 & 401115 & 0750530 & Fischer \& Porter Company & 1993 & 266 & 2 & 9 & 4 & $\mathrm{Z}$ \\
\hline BK-2530 & 401157 & 0750334 & U.S. Naval Air Warfare Center & 1993 & 153 & 8 & 11.5 & 8 & $\mathrm{O}$ \\
\hline BK-2536 & 401145 & 0750328 & U.S. Naval Air Warfare Center & 1993 & 163 & $12 / 8$ & $7 / 135$ & $8 / 4$ & $\mathrm{O}$ \\
\hline BK-2595 & 401209 & 0750410 & U.S. Naval Air Warfare Center & 1994 & 158 & 6 & 14 & 6 & $\mathrm{O}$ \\
\hline BK-2600 & 401205 & 0750352 & U.S. Naval Air Warfare Center & 1994 & 143 & 6 & 14 & 6 & $\mathrm{O}$ \\
\hline BK-2792 & 401225 & 0750434 & U.S. Naval Air Warfare Center & 1995 & 240 & 6 & 18 & 6 & $\mathrm{O}$ \\
\hline BK-2793 & 401225 & 0750434 & U.S. Naval Air Warfare Center & 1995 & 82 & 6 & 18 & 6 & $\mathrm{O}$ \\
\hline BK-2794 & 401225 & 0750434 & U.S. Naval Air Warfare Center & 1995 & 241 & 6 & 18 & 6 & $\mathrm{O}$ \\
\hline \multicolumn{10}{|c|}{ Montgomery County } \\
\hline MG-212 & 401040 & 0750609 & Hatboro Authority & -- & 250 & 12 & 38 & 14 & $\mathbf{U}$ \\
\hline MG-213 & 401041 & 0750609 & Hatboro Authority & -- & 250 & -- & 38 & 10 & $\mathbf{U}$ \\
\hline MG-216 & 401126 & 0750640 & Hatboro Authority & -- & 299 & 10 & 40 & 10 & $\mathbf{P}$ \\
\hline MG-217 & 401051 & 0750643 & Hatboro Authority & 1948 & 288 & 10 & 30 & 10 & $\mathbf{P}$ \\
\hline MG-218 & 401131 & 0750631 & Hatboro Authority & -- & 306 & -- & -- & - & $\mathbf{P}$ \\
\hline MG-219 & 401030 & 0750705 & Hatboro Authority & 1953 & 300 & 10 & 40 & 10 & $\mathbf{P}$ \\
\hline MG-220 & 401056 & 0750638 & Hatboro Authority & 1956 & 475 & 10 & 43 & 10 & $\mathrm{Z}$ \\
\hline MG-942 & 401034 & 0750655 & Hatboro Authority & 1959 & 300 & 10 & $40 / 11$ & $10 / 14$ & $\mathbf{P}$ \\
\hline MG-944 & 401038 & 0750645 & Hatboro Authority & 1964 & 300 & 10 & $41 / 20$ & $10 / 14$ & $\mathbf{P}$ \\
\hline MG-945 & 401030 & 0750628 & Hatboro Authority & 1964 & 300 & 10 & $41 / 20.5$ & $10 / 14$ & $\mathbf{P}$ \\
\hline MG-946 & 401111 & 0750558 & Hatboro Authority & 1969 & 300 & 10 & $40 / 30$ & $10 / 14$ & $\mathbf{U}$ \\
\hline MG-947 & 401103 & 0750608 & Hatboro Authority & -- & 300 & -- & -- & - & $\mathbf{P}$ \\
\hline MG-948 & 401019 & 0750635 & Hatboro Authority & 1971 & 301 & 10 & $47 / 30$ & $10 / 14$ & $\mathbf{P}$ \\
\hline MG-949 & 401037 & 0750720 & Hatboro Authority & 1972 & 300 & 10 & $40 / 40$ & $10 / 16$ & $\mathbf{P}$ \\
\hline MG-950 & 401048 & 0750701 & Hatboro Authority & 1972 & 375 & 10 & 70 & 10 & $\mathbf{P}$ \\
\hline MG-951 & 401055 & 0750625 & Hatboro Authority & 1971 & 335 & 10 & $70 / 30$ & $10 / 14$ & $\mathrm{Z}$ \\
\hline MG-1114 & 401045 & 0750555 & Raymark & 1981 & 151 & 6 & 20 & 6 & $\mathrm{O}$ \\
\hline MG-1115 & 401130 & 0750630 & Hatboro Authority & 1959 & 404 & 10 & 50 & 10 & $\mathrm{O}$ \\
\hline MG-1222 & 401048 & 0750557 & Raymark & 1990 & 200 & 8 & 20 & 8 & $\mathrm{O}$ \\
\hline MG-1223 & 401046 & 0750559 & Raymark & 1990 & 196 & 8 & 6 & 8 & $\mathrm{O}$ \\
\hline MG-1235 & 401046 & 0750556 & Raymark & 1990 & 143 & 6 & -- & 6 & $\mathrm{O}$ \\
\hline MG-1236 & 401048 & 0750603 & U.S. Environmental Protection Agency & -- & 170 & 6 & 14 & 4 & $\mathrm{O}$ \\
\hline MG-1237 & 401050 & 0750602 & U.S. Environmental Protection Agency & 1990 & 169 & 6 & 36 & 4 & $\mathrm{O}$ \\
\hline MG-1238 & 401051 & 0750557 & U.S. Environmental Protection Agency & 1984 & 200 & 6 & 28 & 6 & $\mathrm{O}$ \\
\hline MG-1239 & 401055 & 0750600 & U.S. Environmental Protection Agency & - & 166 & 6 & 31 & 4 & $\mathrm{O}$ \\
\hline MG-1240 & 401059 & 0750554 & U.S. Environmental Protection Agency & 1984 & 159 & 6 & 17 & 4 & $\mathrm{O}$ \\
\hline MG-1241 & 401103 & 0750549 & Fischer \& Porter Company & -- & 175 & 6 & 21 & 6 & $\mathrm{O}$ \\
\hline MG-1242 & 401053 & 0750540 & Fischer \& Porter Company & -. & -178 & 6 & 19 & 6 & $\mathrm{O}$ \\
\hline MG-1283 & 401045 & 0750558 & Raymark & 1992 & 300 & 6 & 240 & 6 & $\mathrm{O}$ \\
\hline
\end{tabular}


Table 7. Results of field determinations

[ $\mu \mathrm{S} / \mathrm{cm}$, microsiemens per centimeter at 25 degrees Celsius; $\mathrm{mg} / \mathrm{L}$, milligrams per liter; --, no data]

\begin{tabular}{|c|c|c|c|c|c|c|c|}
\hline $\begin{array}{l}\text { U.S. Geologlcal } \\
\text { Survey well } \\
\text { number }\end{array}$ & Date & $\begin{array}{l}\text { Samplling } \\
\text { depth } \\
\text { (feet) }\end{array}$ & $\begin{array}{c}\text { pH } \\
\text { (standard } \\
\text { units) }\end{array}$ & $\begin{array}{c}\text { Speclflc } \\
\text { conductance } \\
(\mu \mathrm{S} / \mathrm{cm})\end{array}$ & $\begin{array}{c}\text { Temperature } \\
\text { (degrees } \\
\text { Celslus) }\end{array}$ & $\begin{array}{l}\text { Alkallnity } \\
\text { (mg/L as } \\
\left.\mathrm{CaCO}_{3}\right)\end{array}$ & $\begin{array}{c}\text { Dlssolved } \\
\text { oxygen } \\
\text { (mgll) }\end{array}$ \\
\hline \multicolumn{8}{|c|}{ Bucks County } \\
\hline BK-372 & $03-04-91$ & 241 & 7.0 & 275 & 15.5 & 154 & 7.4 \\
\hline BK-693 & $12-10-90$ & 85 & 5.8 & 220 & 13.5 & 22 & 8.6 \\
\hline \multirow[t]{2}{*}{ BK-948 } & $05-14-74$ & -- & 6.9 & -- & -- & 87 & -- \\
\hline & $11-29-90$ & - & 7.7 & 500 & 13.0 & 171 & 4.2 \\
\hline \multirow[t]{3}{*}{ BK-949 } & $05-14-74$ & -- & 7.4 & -- & -- & 112 & -- \\
\hline & $03-20-91$ & -- & 7.0 & 380 & 14.0 & 146 & 3.0 \\
\hline & $03-20-91$ & -- & 7.0 & 400 & 13.0 & 152 & 3.2 \\
\hline BK-1020 & $04-18-91$ & 70 & 5.6 & 140 & 11.5 & 18 & 12.0 \\
\hline BK-1058 & $03-20-91$ & 105 & 7.6 & 340 & 12.5 & 124 & 4.9 \\
\hline BK-1145 & $08-16-91$ & 50 & 6.9 & 280 & 13.5 & 144 & 1.1 \\
\hline BK-1146 & $07-17-91$ & -. & 7.6 & 480 & 13.0 & 132 & 3.5 \\
\hline BK-1831 & $06-20-91$ & -- & 7.5 & 370 & 19.0 & 120 & 1.2 \\
\hline BK-1832 & $07-17-91$ & 100 & 7.8 & 460 & 13.0 & 189 & 3.8 \\
\hline BK -1833 & $06-21-91$ & 60 & 7.5 & 435 & 19.5 & 164 & 4.1 \\
\hline BK-1834 & $07-17-91$ & 75 & 6.7 & 405 & 17.0 & 100 & 7.3 \\
\hline BK-1843 & $07-18-91$ & 45 & 6.9 & 435 & 14.0 & 130 & 3.7 \\
\hline \multirow[t]{2}{*}{ BK-1844 } & $07-18-91$ & 130 & 7.2 & 1,110 & 15.5 & 97 & 4.2 \\
\hline & $07-18-91$ & 70 & 5.4 & 200 & 18.5 & 13 & 8.5 \\
\hline \multicolumn{8}{|c|}{ Montgomery County } \\
\hline MG-213 & $06-20-91$ & -- & 6.0 & 460 & 14.5 & 50 & 7.1 \\
\hline \multirow[t]{2}{*}{ MG-216 } & $06-27-56$ & -- & 8.4 & 343 & 13.0 & 120 & -- \\
\hline & $06-10-91$ & -- & 7.1 & 435 & 14.5 & 148 & 5.3 \\
\hline \multirow[t]{2}{*}{ MG-217 } & $06-27-56$ & -- & 7.6 & 403 & 14.0 & 113 & -- \\
\hline & $06-10-91$ & -- & 7.5 & 545 & 15.0 & 194 & 4.0 \\
\hline \multirow[t]{3}{*}{ MG-218 } & $06-27-56$ & -- & 8.2 & 407 & 12.0 & 115 & -- \\
\hline & 01-18-91 & 120 & 6.3 & 360 & 12.0 & 104 & 5.8 \\
\hline & $06-10-91$ & -- & 7.2 & 480 & 14.5 & 172 & 6.5 \\
\hline \multirow[t]{3}{*}{ MG-219 } & $06-27-56$ & -- & 8.0 & 286 & 13.0 & 112 & -- \\
\hline & $10-23-79$ & -- & 6.6 & 395 & 12.0 & 110 & -- \\
\hline & 06-20-91 & -- & 6.7 & 475 & 14.0 & 116 & 5.0 \\
\hline MG-220 & $11-15-90$ & 130 & 7.7 & 490 & 12.5 & 184 & 2.1 \\
\hline MG-942 & $06-10-91$ & -- & 7.0 & 470 & 15.0 & 136 & 3.9 \\
\hline MG-944 & $06-10-91$ & -- & 7.4 & 600 & 14.5 & 206 & 3.7 \\
\hline MG-945 & $08-16-91$ & -- & 6.9 & 505 & 14.5 & 177 & 4.3 \\
\hline MG-946 & $04-16-92$ & -- & 7.3 & 650 & 13.5 & 204 & 3.3 \\
\hline \multirow[t]{2}{*}{ MG-947 } & $06-20-91$ & -- & 7.2 & 670 & 14.0 & 170 & 4.5 \\
\hline & $06-10-91$ & -- & 7.3 & 690 & 15.0 & 170 & 4.8 \\
\hline MG-948 & $08-16-91$ & -- & 6.8 & 560 & 20.0 & 174 & 2.1 \\
\hline MG-949 & $08-16-91$ & -- & 7.0 & 360 & 15.0 & 152 & 2.9 \\
\hline MG-950 & $08-16-91$ & -- & 7.4 & 515 & 14.0 & 140 & 4.0 \\
\hline \multirow[t]{2}{*}{ MG-951 } & $12-10-90$ & 55 & 6.9 & 550 & 14.0 & 160 & 5.6 \\
\hline & $12-10-90$ & 105 & 7.0 & 550 & 14.0 & 158 & 5.6 \\
\hline \multirow[t]{2}{*}{ MG-1115 } & $11-14-90$ & 248 & 6.4 & 530 & -- & 74 & 5.5 \\
\hline & $11-14-90$ & 100 & 6.3 & 375 & -- & 70 & 6.5 \\
\hline MG-1235 & $05-17-91$ & -- & 6.4 & 425 & 15.0 & 106 & 4.0 \\
\hline \multirow[t]{2}{*}{ MG-1236 } & $11-16-90$ & 85 & 6.5 & 390 & 16.5 & 78 & 5.6 \\
\hline & $06-05-91$ & 85 & 6.3 & 345 & 14.5 & 63 & 6.7 \\
\hline \multirow[t]{2}{*}{ MG-1237 } & $11-15-90$ & 60 & 7.0 & 480 & 15.5 & 160 & 4.2 \\
\hline & $11-15-90$ & 85 & 7.1 & 510 & 14.5 & 156 & 3.2 \\
\hline MG-1238 & $11-16-90$ & 110 & 6.4 & 470 & 12.5 & 112 & 3.4 \\
\hline \multirow[t]{2}{*}{ MG-1239 } & $11-30-90$ & 60 & 7.5 & 580 & 11.5 & 201 & 4.0 \\
\hline & $11-30-90$ & 80 & 7.6 & 560 & 12.5 & 198 & 2.0 \\
\hline \multirow[t]{2}{*}{ MG-1240 } & $11-29-90$ & 90 & 6.4 & 1180 & 13.5 & 116 & 3.2 \\
\hline & $11-29-90$ & 60 & 6.4 & 1120 & 12.0 & 120 & 3.8 \\
\hline MG-1241 & $12-13-90$ & 110 & 6.6 & 600 & 14.0 & 176 & 3.6 \\
\hline MG-1242 & $12-13-90$ & 90 & 6.7 & 500 & 13.0 & 150 & 8.0 \\
\hline
\end{tabular}


Table 8. Results of chemical analyses for inorganic constituents

[mg/L, milligrams per liter; $\mu \mathrm{g} / \mathrm{L}$, micrograms per liter; $\mathrm{pCi} / \mathrm{L}$, picoCuries per liter; <, less than; --, no data; total dissolved solids is residue on evaporation at 180 degrees Celsius]

\begin{tabular}{|c|c|c|c|c|c|c|c|c|c|c|}
\hline $\begin{array}{l}\text { U.S. Geological } \\
\text { Survey well } \\
\text { number }\end{array}$ & Date & $\begin{array}{l}\text { Samplling } \\
\text { depth } \\
\text { (feet) }\end{array}$ & $\begin{array}{l}\text { Calclum, } \\
\text { dlssolved } \\
\text { (mg/l as } \\
\text { Ca) }\end{array}$ & $\begin{array}{l}\text { Magne- } \\
\text { slum, } \\
\text { dlssolved } \\
\text { (mg/L as } \\
\text { Mg) }\end{array}$ & $\begin{array}{c}\text { Sodlum, } \\
\text { dlssolved } \\
\text { (mg/l as } \\
\mathrm{Na} \text { ) }\end{array}$ & $\begin{array}{l}\text { Potasslum, } \\
\text { dlssolved } \\
\text { (mg/L as K) }\end{array}$ & $\begin{array}{c}\text { Sulfate, } \\
\text { dlssolved } \\
\text { (mg/L as } \\
\left.\mathrm{SO}_{4}\right)\end{array}$ & $\begin{array}{l}\text { Chloride, } \\
\text { dlssolved } \\
\text { (mg/l as as } \\
\text { Cl) }\end{array}$ & $\begin{array}{l}\text { Sillca, } \\
\text { dlssolved } \\
\text { (mg/L as } \\
\left.\mathrm{SiO}_{2}\right)\end{array}$ & $\begin{array}{l}\text { Total } \\
\text { dissolved } \\
\text { sollds } \\
\text { (mg/l) }\end{array}$ \\
\hline \multicolumn{11}{|c|}{ Bucks County } \\
\hline BK-372 & $03-04-91$ & 241 & 28 & 8.8 & 5.8 & 1.3 & 13 & 12 & 11 & 134 \\
\hline BK-693 & $12-10-90$ & 85 & 16 & 5.2 & 15 & .9 & 24 & 31 & 25 & 128 \\
\hline \multirow[t]{2}{*}{ BK-948 } & $05-14-74$ & -- & -- & -- & -- & -- & 110 & -- & -- & 420 \\
\hline & $11-29-90$ & -- & 45 & 28 & 17 & 1.8 & 25 & 34 & 18 & 272 \\
\hline \multirow[t]{3}{*}{ BK-949 } & $05-14-74$ & -- & -- & -- & -- & -- & 24 & 12 & -- & 278 \\
\hline & $03-20-91$ & -- & 47 & 15 & 13 & .9 & 16 & 21 & 29 & 225 \\
\hline & $03-20-91$ & -- & 47 & 15 & 12 & 1.0 & 17 & 27 & 29 & 223 \\
\hline BK-1020 & $04-18-91$ & 70 & 9.4 & 4.0 & 10 & 1.2 & 36 & 4.5 & 24 & 101 \\
\hline BK-1058 & $03-20-91$ & 105 & 56 & 5.6 & 7.3 & 1.4 & 24 & 11 & 17 & 197 \\
\hline BK-1145 & $08-16-91$ & 50 & 48 & 9.0 & 15 & 1.2 & 20 & 14 & 20 & 205 \\
\hline BK-1146 & $07-17-91$ & -- & 55 & 9.1 & 27 & 2.1 & 72 & 16 & 18 & 279 \\
\hline BK-1831 & $06-20-91$ & -- & 36 & 9.5 & 12 & 1.7 & 22 & 3.3 & 24 & 164 \\
\hline BK-1832 & $07-17-91$ & 100 & 52 & 20 & 9.7 & 1.1 & 12 & 17 & 23 & 252 \\
\hline BK-1833 & $06-21-91$ & 60 & 45 & 18 & 12 & 2.6 & 7.5 & 27 & 20 & 232 \\
\hline BK-1834 & $07-17-91$ & 75 & 46 & 11 & 11 & .8 & 31 & 25 & 28 & 216 \\
\hline BK-1843 & $07-18-91$ & 45 & 57 & 11 & 12 & .9 & 32 & 34 & 25 & 235 \\
\hline \multirow[t]{2}{*}{ BK-1844 } & $07-18-91$ & 130 & 180 & 21 & 43 & 2.1 & 500 & 28 & 20 & 856 \\
\hline & $07-18-91$ & 70 & 13 & 2.6 & 17 & .9 & 29 & 20 & 31 & 119 \\
\hline \multicolumn{11}{|c|}{ Montgomery County } \\
\hline MG-213 & $06-20-91$ & -- & 30 & 8.5 & 25 & 1.2 & 31 & 48 & 25 & 199 \\
\hline \multirow[t]{2}{*}{ MG-216 } & $06-27-56$ & - & 38 & 11 & -. & -- & 25 & 14 & 32 & 264 \\
\hline & $06-10-91$ & -- & 43 & 14 & 16 & .9 & 26 & 34 & 23 & 240 \\
\hline \multirow[t]{2}{*}{ MG-217 } & $06-27-56$ & -- & 31 & 10 & -. & - & 70 & 8.5 & 24 & 279 \\
\hline & $06-10-91$ & -- & 53 & 18 & 26 & 2.0 & 36 & 46 & 20 & 306 \\
\hline \multirow[t]{3}{*}{ MG-218 } & $06-27-56$ & -- & 41 & 10 & -- & -- & 64 & 11 & 29 & 274 \\
\hline & $01-18-91$ & 120 & 42 & 10 & 16 & 1.0 & 15 & 35 & 23 & 205 \\
\hline & $06-10-91$ & -- & 52 & 16 & 20 & 1.3 & 30 & 33 & 24 & 275 \\
\hline \multirow[t]{3}{*}{ MG-219 } & $06-27-56$ & -- & 40 & 5.2 & -- & -- & 23 & 10 & 26 & 197 \\
\hline & $10-23-79$ & -- & 44 & 9.2 & 16 & 1.5 & 27 & 19 & 23 & 220 \\
\hline & $06-20-91$ & -- & 52 & 10 & 16 & 1.5 & 17 & 36 & 21 & 232 \\
\hline MG-220 & $11-15-90$ & 130 & 55 & 24 & 15 & 1.7 & 34 & 41 & 18 & 282 \\
\hline MG-942 & $06-10-91$ & -- & 58 & 9.8 & 15 & 1.0 & 31 & 40 & 23 & 258 \\
\hline MG-944 & $06-10-91$ & -- & 73 & 16 & 28 & 1.3 & 61 & 45 & 22 & 355 \\
\hline MG-945 & $08-16-91$ & -- & 77 & 14 & 25 & 1.3 & 50 & 52 & 22 & 348 \\
\hline MG-946 & $04-16-92$ & -- & 85 & 25 & 22 & 1.2 & 35 & 93 & 22 & 388 \\
\hline \multirow[t]{2}{*}{ MG-947 } & $06-20-91$ & -- & 68 & 24 & 22 & 1.1 & 21 & 83 & 24 & 359 \\
\hline & $06-10-91$ & -- & 68 & 23 & 22 & 1.1 & 29 & 96 & 25 & 405 \\
\hline MG-948 & $08-16-91$ & -- & 60 & 14 & 25 & 1.8 & 48 & 39 & 21 & 302 \\
\hline MG-949 & $08-16-91$ & -- & 45 & 18 & 16 & 1.3 & 28 & 30 & 22 & 255 \\
\hline MG-950 & $08-16-91$ & -- & 55 & 17 & 28 & 2.7 & 94 & 33 & 21 & 316 \\
\hline \multirow[t]{2}{*}{ MG-951 } & $12-10-90$ & 55 & 64 & 18 & 21 & 1.3 & 35 & 53 & 25 & 361 \\
\hline & $12-10-90$ & 105 & 64 & 19 & 21 & 1.3 & 35 & 53 & 25 & 335 \\
\hline \multirow[t]{2}{*}{ MG-1115 } & $11-14-90$ & 248 & 58 & 11 & 29 & 1.4 & 69 & 50 & 22 & 232 \\
\hline & $11-14-90$ & 100 & $<36$ & 7.5 & 24 & 1.3 & 9.9 & 53 & 22 & 209 \\
\hline MG-1235 & $05-17-91$ & -- & 48 & 10 & 18 & .9 & 20 & 22 & 32 & 253 \\
\hline \multirow[t]{2}{*}{ MG-1236 } & $11-16-90$ & 85 & 42 & 8.9 & 19 & 1.3 & 33 & 38 & 25 & 233 \\
\hline & $06-05-91$ & 85 & 38 & 8.2 & 19 & 1.3 & 38 & 42 & 26 & 237 \\
\hline \multirow[t]{2}{*}{ MG-1237 } & $11-15-90$ & 60 & 72 & 8.5 & 13 & .8 & 18 & 41 & 28 & 298 \\
\hline & $11-15-90$ & 85 & 74 & 8.6 & 14 & .9 & 8.9 & 42 & 27 & 295 \\
\hline MG-1238 & $11-16-90$ & 110 & 59 & 8.5 & 25 & 1.3 & 30 & 62 & 37 & 308 \\
\hline \multirow[t]{2}{*}{ MG-1239 } & $11-30-90$ & 60 & 64 & 29 & 23 & 1.6 & 29 & 43 & 28 & 353 \\
\hline & $11-30-90$ & 80 & 53 & 29 & 22 & 1.9 & 23 & 44 & 26 & 319 \\
\hline MG-1240 & $11-29-90$ & 90 & 66 & 19 & 130 & 2.8 & 53 & 240 & 22 & 624 \\
\hline & $11-29-90$ & 60 & 68 & 20 & 130 & 2.8 & 53 & 240 & 22 & 620 \\
\hline MG-1241 & $12-13-90$ & 110 & 86 & 14 & 18 & 1.0 & 35 & 63 & 30 & 384 \\
\hline MG-1242 & $12-13-90$ & 90 & 54 & 21 & 14 & .9 & 16 & 50 & 24 & 277 \\
\hline
\end{tabular}

44 Geohydrology of the Stockton Formation and Cross-Contamination Through Open Boreholes, Hatboro Borough and Warminster Township, Pennsylvanla 
Table 8. Results of chemical analyses for inorganic constituents-Continued

$[\mathrm{mg} / \mathrm{L}$, milligrams per liter; $\mu \mathrm{g} / \mathrm{L}$, micrograms per liter; $\mathrm{pCi} / \mathrm{L}$, picoCuries per liter; <, less than; --, no data; total dissolved solids is residue on evaporation at 180 degrees Celsius]

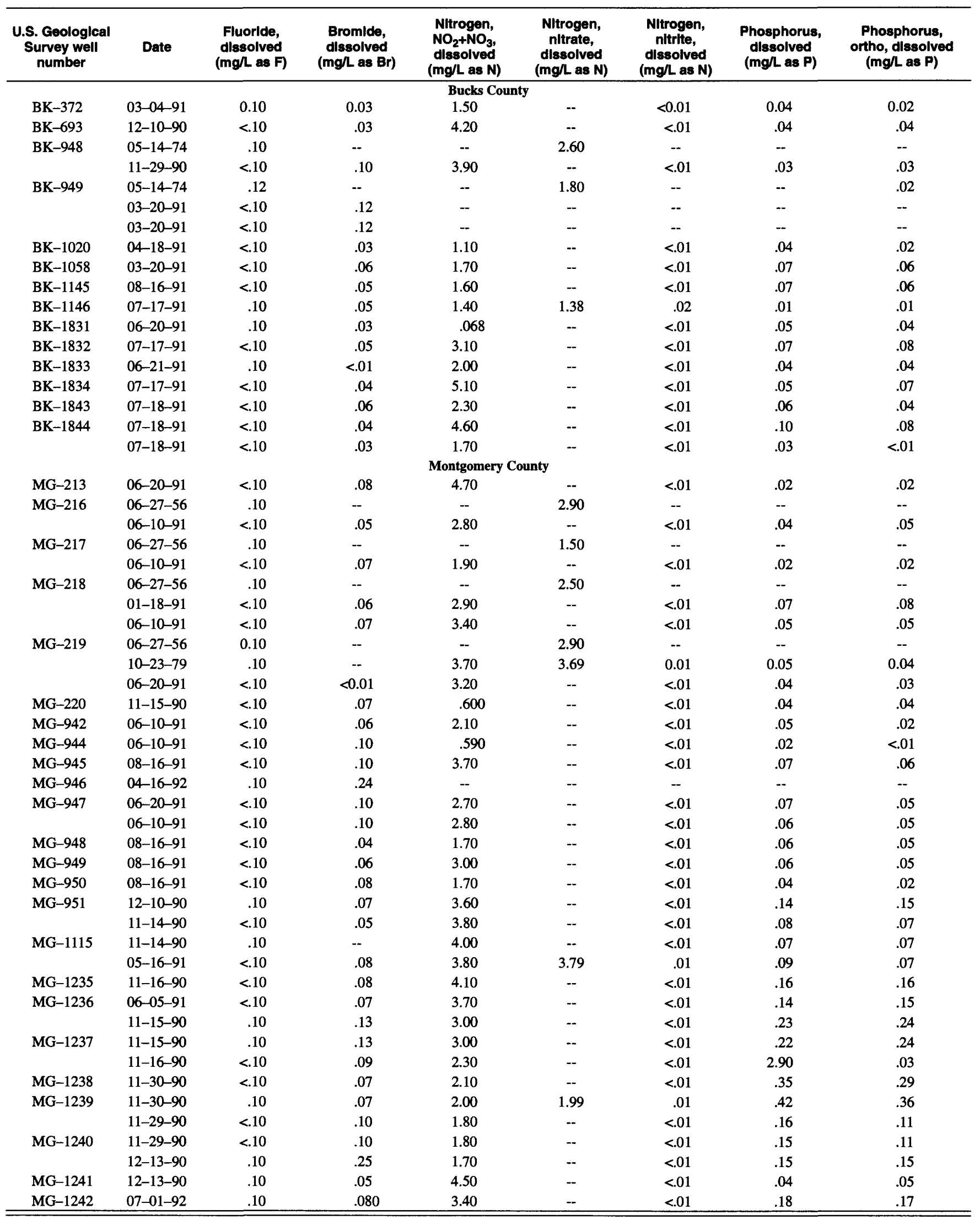


Table 8. Results of chemical analyses for inorganic constituents-Continued

[mg/L, milligrams per liter; $\mu \mathrm{g} / \mathrm{L}$, micrograms per liter; $\mathrm{pCi} / \mathrm{L}$, picoCuries per liter; <, less than; --, no data; total dissolved solids is residue on evaporation at 180 degrees Celsius]

\begin{tabular}{|c|c|c|c|c|c|c|c|c|}
\hline $\begin{array}{l}\text { U.S. Geologlcal } \\
\text { Survey well } \\
\text { number }\end{array}$ & Date & $\begin{array}{l}\text { Aluminum, } \\
\text { dlsssoived } \\
(\mu g / \text { as Al) }\end{array}$ & $\begin{array}{c}\text { Barlum, } \\
\text { dissoived } \\
\text { ( } \mu \mathrm{g} / \mathrm{L} \text { as Ba) }\end{array}$ & $\begin{array}{c}\text { Iron, } \\
\text { dlssolved } \\
(\mu \mathrm{g} / \mathrm{L} \text { as Fe) }\end{array}$ & $\begin{array}{c}\text { Lead, } \\
\text { dlssolved } \\
(\mu \mathrm{g} / \mathrm{L} \text { as } \mathrm{Pb})\end{array}$ & $\begin{array}{c}\text { Manganese, } \\
\text { dlssolved } \\
(\mu g / \text { as } M n)\end{array}$ & $\begin{array}{l}\text { Strontlum, } \\
\text { dlssolved } \\
\text { (mg/L as Sr) }\end{array}$ & $\begin{array}{c}\text { Radon, } \\
\text { total } \\
\text { (pCl/L) }\end{array}$ \\
\hline & & & & Bucks County & & & & \\
\hline BK-372 & 03-04-91 & 20 & 99 & 8 & $<1$ & 5 & 150 & 610 \\
\hline BK-693 & $12-10-90$ & $<10$ & 150 & 8 & $<1$ & 4 & 38 & 1,400 \\
\hline \multirow[t]{2}{*}{ BK-948 } & $05-14-74$ & -- & -- & 110 & -- & $<10$ & .- & -- \\
\hline & $11-29-90$ & $<10$ & 250 & $<3$ & $<1$ & 23 & 850 & 1,000 \\
\hline \multirow[t]{3}{*}{ BK-949 } & $05-14-74$ & - & -- & 30 & -- & $<10$ & - & -- \\
\hline & $03-20-91$ & $<10$ & 460 & 7 & $<1$ & 3 & 96 & 1,600 \\
\hline & $03-20-91$ & 20 & 460 & 10 & $<1$ & 4 & 97 & 1,500 \\
\hline BK-1020 & 04-18-91 & $<10$ & 21 & 100 & $<1$ & 3 & 34 & 2900 \\
\hline BK-1058 & $03-20-91$ & 20 & 380 & 6 & $<1$ & 1 & 81 & 1,700 \\
\hline BK-1145 & $08-16-91$ & $<10$ & 260 & 35 & $<1$ & 10 & 420 & 4,100 \\
\hline BK-1146 & $07-17-91$ & 10 & 120 & 6 & 2 & 10 & 1,500 & 2,100 \\
\hline BK-1831 & $06-20-91$ & $<10$ & 260 & 6 & 2 & 36 & 290 & 2,500 \\
\hline BK-1832 & $07-17-91$ & $<10$ & 450 & 12 & $<1$ & 8 & 190 & 2,200 \\
\hline BK-1833 & $06-21-91$ & 1 & 520 & 12 & 1 & 3 & 600 & 3,100 \\
\hline BK-1834 & $07-17-91$ & $<10$ & 66 & 4 & $<1$ & 3 & 470 & 2,400 \\
\hline BK-1843 & $07-18-91$ & $<10$ & 73 & 9 & $<1$ & 5 & 730 & 4,100 \\
\hline \multirow[t]{2}{*}{ BK-1844 } & $07-18-91$ & $<10$ & 120 & 7 & $<1$ & 64 & 5,000 & 3,900 \\
\hline & $07-18-91$ & $<10$ & 160 & 4 & $<1$ & 3 & 37 & 3,400 \\
\hline \multicolumn{9}{|c|}{ Montgomery County } \\
\hline MG-213 & $06-20-91$ & $<10$ & 82 & 280 & 1 & 12 & 70 & 2,100 \\
\hline \multirow{2}{*}{ MG-216 } & $06-27-56$ & -- & -- & 100 & -- & -- & -- & -- \\
\hline & $06-10-91$ & $<10$ & 310 & $<3$ & 1 & $<1$ & 130 & 1,700 \\
\hline \multirow[t]{2}{*}{ MG-217 } & $06-27-56$ & -- & -- & 200 & -- & -- & -- & -- \\
\hline & $06-10-91$ & $<10$ & 190 & $<3$ & 1 & $<1$ & 490 & 1,400 \\
\hline \multirow[t]{3}{*}{ MG-218 } & $06-27-56$ & -- & -- & 40 & -- & -- & -- & -- \\
\hline & $01-18-91$ & $<10$ & 450 & 7 & $<1$ & 2 & -- & 1,700 \\
\hline & $06-10-91$ & $<10$ & 340 & 6 & $<1$ & 2 & 230 & 1,400 \\
\hline \multirow[t]{3}{*}{ MG-219 } & $06-27-56$ & -- & -- & 110 & -- & -- & -- & -- \\
\hline & $10-23-79$ & -- & -- & 0 & 0 & 4 & -- & -- \\
\hline & $06-20-91$ & $<1$ & 350 & $<3$ & 1 & $<1$ & 200 & 1,900 \\
\hline MG-220 & $11-15-90$ & $<10$ & 220 & 23 & $<1$ & 4 & 250 & 2,000 \\
\hline MG-942 & $06-10-91$ & $<10$ & 260 & $<3$ & 1 & 5 & 170 & 1,200 \\
\hline MG-944 & $06-10-91$ & $<10$ & 77 & 22 & 1 & 98 & 930 & 1,000 \\
\hline MG-945 & $08-16-91$ & 10 & 140 & 6 & 2 & 7 & 250 & 1,100 \\
\hline MG-946 & $04-16-92$ & 10 & 250 & 23 & $<1$ & 5 & 290 & 1,400 \\
\hline \multirow{2}{*}{ MG-947 } & $06-20-91$ & $<10$ & 360 & 3 & 2 & 2 & 110 & -- \\
\hline & $06-10-91$ & $<10$ & 370 & 5 & $<1$ & 2 & 110 & 1,600 \\
\hline MG-948 & $08-16-91$ & $<10$ & 170 & $<3$ & 1 & 4 & 310 & 1,700 \\
\hline MG-949 & $08-16-91$ & $<10$ & 350 & $<3$ & $<1$ & 2 & 100 & 1,200 \\
\hline MG-950 & $08-16-91$ & $<10$ & 160 & $<3$ & 1 & 1 & 750 & 1,500 \\
\hline \multirow[t]{2}{*}{ MG-951 } & $12-10-90$ & $<10$ & 210 & 10 & $<1$ & 5 & 74 & 1,400 \\
\hline & $12-10-90$ & $<10$ & 230 & 7 & 1 & 2 & 78 & 1,300 \\
\hline \multirow[t]{2}{*}{ MG-1115 } & $11-14-90$ & $<10$ & 130 & $<3$ & $<1$ & 14 & 120 & 170 \\
\hline & $11-14-90$ & $<10$ & 160 & 4 & $<1$ & 12 & 55 & 170 \\
\hline MG-1235 & $05-17-91$ & $<10$ & 110 & 11 & 1 & $<1$ & 55 & 1,900 \\
\hline \multirow[t]{2}{*}{ MG-1236 } & $11-16-90$ & $<10$ & 160 & 15 & 1 & 3 & 42 & 1,400 \\
\hline & $06-05-91$ & $<10$ & 160 & 16 & $<1$ & 3 & 45 & 1,500 \\
\hline \multirow[t]{2}{*}{ MG-1237 } & $11-15-90$ & $<10$ & 420 & 4 & 1 & $<1$ & 43 & -- \\
\hline & $11-15-90$ & $<10$ & 440 & 3 & $<1$ & 8 & 44 & -- \\
\hline MG-1238 & $11-16-90$ & $<10$ & 370 & 5 & $<1$ & 8 & 56 & 1,500 \\
\hline \multirow[t]{2}{*}{ MG-1239 } & $11-30-90$ & $<10$ & 360 & $<3$ & $<1$ & 2 & 230 & -- \\
\hline & $11-30-90$ & $<10$ & 410 & $<3$ & $<1$ & 1 & 250 & -- \\
\hline \multirow[t]{2}{*}{ MG-1240 } & $11-29-90$ & $<10$ & 95 & 5 & $<1$ & 270 & 180 & -- \\
\hline & $11-29-90$ & 10 & 100 & 5 & $<1$ & 280 & 180 & -- \\
\hline MG-1241 & $12-13-90$ & 20 & 300 & 14 & $<1$ & 4 & 70 & 1,100 \\
\hline MG-1242 & $12-13-90$ & 10 & 400 & 7 & $<1$ & $<1$ & 100 & 1,200 \\
\hline
\end{tabular}

46 Geohydrology of the Stockton Formation and Cross-Contamination Through Open Boreholes,

Hatboro Borough and Warminster Township, Pennsyivania 
Table 9. Results of chemical analysis for volatile organic compounds

[All results are total concentrations in micrograms per liter; <, less than; --, no data]

\begin{tabular}{|c|c|c|c|c|c|c|c|c|c|c|c|c|c|}
\hline $\begin{array}{l}\text { U.S. Geological } \\
\text { Survey } \\
\text { well number }\end{array}$ & Date & $\begin{array}{l}\text { Sampling } \\
\text { depth } \\
\text { (feet) }\end{array}$ & Benzene & $\begin{array}{l}\text { Bromo- } \\
\text { form }\end{array}$ & $\begin{array}{l}\text { 1,2- } \\
\text { Dibromo- } \\
\text { ethane }\end{array}$ & $\begin{array}{c}\text { Carbon } \\
\text { tetra- } \\
\text { chioride }\end{array}$ & $\begin{array}{l}\text { Chioro- } \\
\text { benzene }\end{array}$ & $\begin{array}{c}\text { 1,2- } \\
\text { Dichioro- } \\
\text { benzene }\end{array}$ & $\begin{array}{l}\text { 1,3- } \\
\text { Dichioro- } \\
\text { benzene }\end{array}$ & $\begin{array}{c}\text { 1,4- } \\
\text { Dichioro- } \\
\text { benzene }\end{array}$ & $\begin{array}{l}\text { Chioro- } \\
\text { dibromo- } \\
\text { methane }\end{array}$ & $\begin{array}{l}\text { Chioro- } \\
\text { ethane }\end{array}$ & $\begin{array}{l}\text { 2- } \\
\text { Chioro- } \\
\text { ethyi- } \\
\text { vinyi- } \\
\text { ether }\end{array}$ \\
\hline \multicolumn{14}{|c|}{ Bucks County } \\
\hline $\mathrm{BK}-372$ & 03-04-91 & 241 & $<0.2$ & $<0.2$ & $<0.2$ & $<0.2$ & $<0.2$ & $<0.2$ & $<0.2$ & $<0.2$ & $<0.2$ & $<0.2$ & $<0.2$ \\
\hline BK-693 & $12-10-90$ & 85 & $<.2$ & $<.2$ & $<.2$ & $<.2$ & $<.2$ & $<.2$ & $<.2$ & $<.2$ & $<.2$ & $<.2$ & $<.2$ \\
\hline BK-948 & $11-29-90$ & 120 & $<.2$ & $<.2$ & $<.2$ & $<.2$ & $<.2$ & $<.2$ & $<.2$ & $<.2$ & $<.2$ & $<.2$ & $<.2$ \\
\hline \multirow[t]{2}{*}{ BK-949 } & $03-20-91$ & 135 & $<.2$ & $<.2$ & $<.2$ & $<.2$ & $<.2$ & $<.2$ & $<.2$ & $<.2$ & $<.2$ & $<.2$ & $<.2$ \\
\hline & $03-20-91$ & 135 & $<.2$ & $<.2$ & $<.2$ & $<.2$ & $<.2$ & $<.2$ & $<.2$ & $<.2$ & $<.2$ & $<.2$ & $<.2$ \\
\hline BK-1020 & $04-18-91$ & 70 & $<.2$ & $<.2$ & $<.2$ & $<.2$ & $<.2$ & $<.2$ & $<.2$ & $<.2$ & $<.2$ & $<.2$ & $<.2$ \\
\hline $\mathrm{BK}-1058$ & $03-20-91$ & 105 & $<.2$ & $<.2$ & $<.2$ & $<.2$ & $<.2$ & $<.2$ & $<.2$ & $<.2$ & $<.2$ & $<.2$ & $<.2$ \\
\hline $\mathrm{BK}-1145$ & $08-16-91$ & 50 & $<.2$ & $<.2$ & $<.2$ & $<.2$ & $<.2$ & $<.2$ & $<.2$ & $<.2$ & $<.2$ & $<.2$ & $<.2$ \\
\hline BK-1146 & $07-17-91$ & -- & $<.2$ & $<.2$ & $<.2$ & $<.2$ & $<.2$ & $<.2$ & $<.2$ & $<.2$ & $<.2$ & $<.2$ & $<.2$ \\
\hline BK-1831 & $06-20-91$ & -- & $<.2$ & $<.2$ & $<.2$ & $<.2$ & $<.2$ & $<.2$ & $<.2$ & $<.2$ & $<.2$ & $<.2$ & $<.2$ \\
\hline BK-1832 & $07-17-91$ & 100 & $<.2$ & $<.2$ & $<.2$ & $<.2$ & $<.2$ & $<.2$ & $<.2$ & $<.2$ & $<.2$ & $<.2$ & $<.2$ \\
\hline BK-1833 & $06-21-91$ & 60 & $<.2$ & $<.2$ & $<.2$ & $<.2$ & $<.2$ & $<.2$ & $<.2$ & $<.2$ & $<.2$ & $<.2$ & $<.2$ \\
\hline BK-1834 & $07-17-91$ & 75 & $<.2$ & $<.2$ & $<.2$ & $<.2$ & $<.2$ & $<.2$ & $<.2$ & $<.2$ & $<.2$ & $<.2$ & $<.2$ \\
\hline BK-1843 & $07-18-91$ & 45 & $<.2$ & $<.2$ & $<.2$ & $<.2$ & $<.2$ & $<.2$ & $<.2$ & $<.2$ & $<.2$ & $<.2$ & $<.2$ \\
\hline BK-1844 & $07-18-91$ & 130 & $<.2$ & $<.2$ & $<.2$ & $<.2$ & $<.2$ & $<.2$ & $<.2$ & $<.2$ & $<.2$ & $<.2$ & $<.2$ \\
\hline \multicolumn{14}{|c|}{ Montgomery County } \\
\hline MG-213 & $06-20-91$ & -- & $<.2$ & $<.2$ & $<.2$ & $<.2$ & $<.2$ & $<.2$ & $<.2$ & $<.2$ & $<.2$ & $<.2$ & $<.2$ \\
\hline MG-216 & $06-10-91$ & -- & $<.2$ & $<.2$ & $<.2$ & $<.2$ & $<.2$ & $<.2$ & $<.2$ & $<.2$ & $<.2$ & $<.2$ & $<.2$ \\
\hline MG-217 & $06-10-91$ & -- & $<.2$ & $<.2$ & $<.2$ & $<.2$ & $<.2$ & $<.2$ & $<.2$ & $<.2$ & $<.2$ & $<.2$ & $<.2$ \\
\hline \multirow[t]{2}{*}{ MG-218 } & 01-18-91 & 120 & $<.2$ & $<.2$ & $<.2$ & $<.2$ & $<.2$ & $<.2$ & $<.2$ & $<.2$ & $<.2$ & $<.2$ & $<.2$ \\
\hline & $06-10-91$ & -- & $<.2$ & $<.2$ & $<.2$ & $<.2$ & $<.2$ & $<.2$ & $<.2$ & $<.2$ & $<.2$ & $<.2$ & $<.2$ \\
\hline MG-219 & $06-20-91$ & -- & $<.2$ & $<.2$ & $<.2$ & $<.2$ & $<.2$ & $<.2$ & $<.2$ & $<.2$ & $<.2$ & $<.2$ & $<.2$ \\
\hline MG-220 & $11-15-90$ & 130 & $<.2$ & $<.2$ & $<.2$ & $<.2$ & $<.2$ & $<.2$ & $<.2$ & $<.2$ & $<.2$ & $<.2$ & $<.2$ \\
\hline MG-942 & $06-10-91$ & -- & $<.2$ & $<.2$ & $<.2$ & $<.2$ & $<.2$ & $<.2$ & $<.2$ & $<.2$ & $<.2$ & $<.2$ & $<.2$ \\
\hline MG-944 & $06-10-91$ & -- & .2 & $<.2$ & $<.2$ & $<.2$ & $<.2$ & $<.2$ & $<.2$ & $<.2$ & $<.2$ & $<.2$ & $<.2$ \\
\hline MG-945 & $08-16-91$ & - & $<.2$ & $<.2$ & $<.2$ & $<.2$ & $<.2$ & $<.2$ & $<.2$ & $<.2$ & $<.2$ & $<.2$ & $<.2$ \\
\hline MG-946 & $04-16-92$ & -- & $<.2$ & $<.2$ & $<.2$ & $<.2$ & $<.2$ & $<.2$ & $<.2$ & $<.2$ & $<.2$ & $<.2$ & $<1.0$ \\
\hline MG-947 & $06-10-91$ & -- & $<.2$ & $<.2$ & $<.2$ & .3 & $<.2$ & $<.2$ & $<.2$ & $<.2$ & $<.2$ & $<.2$ & $<.2$ \\
\hline MG-948 & $08-16-91$ & -- & $<.2$ & 2.1 & $<.2$ & $<.2$ & $<.2$ & $<.2$ & $<.2$ & $<.2$ & 1.6 & $<.2$ & $<.2$ \\
\hline MG-949 & 08-16-91 & -- & $<.2$ & $<.2$ & $<.2$ & $<.2$ & $<.2$ & $<.2$ & $<.2$ & $<.2$ & $<.2$ & $<.2$ & $<.2$ \\
\hline MG-950 & $08-16-91$ & -- & $<.2$ & $<.2$ & $<.2$ & $<.2$ & $<.2$ & $<.2$ & $<.2$ & $<.2$ & $<.2$ & $<.2$ & $<.2$ \\
\hline \multirow[t]{2}{*}{ MG-951 } & $12-10-90$ & 55 & $<.2$ & $<.2$ & $<.2$ & $<.2$ & $<.2$ & $<.2$ & $<.2$ & $<.2$ & $<.2$ & $<.2$ & $<.2$ \\
\hline & $12-10-90$ & 105 & $<.2$ & $<.2$ & $<.2$ & $<.2$ & $<.2$ & $<.2$ & $<.2$ & $<.2$ & $<.2$ & $<.2$ & $<.2$ \\
\hline \multirow[t]{2}{*}{ MG-1115 } & $11-14-90$ & 248 & $<.2$ & $<.2$ & $<.2$ & $<.2$ & $<.2$ & $<.2$ & $<.2$ & $<.2$ & $<.2$ & $<.2$ & $<.2$ \\
\hline & $11-14-90$ & 100 & $<.2$ & $<.2$ & $<.2$ & $<.2$ & $<.2$ & $<.2$ & $<.2$ & $<.2$ & $<.2$ & $<.2$ & $<.2$ \\
\hline MG-1235 & $05-17-91$ & -- & $<.2$ & $<.2$ & $<.2$ & $<.2$ & $<.2$ & $<.2$ & $<.2$ & $<.2$ & $<.2$ & $<.2$ & $<.2$ \\
\hline \multirow[t]{4}{*}{ MG-1236 } & $11-16-90$ & 85 & $<2.0$ & $<2.0$ & $<2.0$ & 2.6 & $<2.0$ & $<2.0$ & $<2.0$ & $<2.0$ & $<2.0$ & $<2.0$ & $<2.0$ \\
\hline & $06-05-91$ & 85 & $<.2$ & $<.2$ & $<.2$ & 2.0 & $<.2$ & $<.2$ & $<.2$ & $<.2$ & $<.2$ & $<.2$ & $<.2$ \\
\hline & $06-16-92$ & 60 & $<.2$ & .4 & $<.2$ & .2 & $<.2$ & $<.2$ & $<.2$ & $<.2$ & .2 & $<.2$ & $<.2$ \\
\hline & $06-16-92$ & 85 & $<.2$ & $<.2$ & $<.2$ & 1.5 & $<.2$ & $<.2$ & $<.2$ & $<.2$ & $<.2$ & $<.2$ & $<.2$ \\
\hline \multirow[t]{3}{*}{ MG-1237 } & $11-15-90$ & 60 & $<.2$ & $<.2$ & $<.2$ & 20 & $<.2$ & $<.2$ & $<.2$ & $<.2$ & $<.2$ & $<.2$ & $<.2$ \\
\hline & $11-15-90$ & 85 & $<.2$ & $<.2$ & $<.2$ & 19 & $<.2$ & $<.2$ & $<.2$ & $<.2$ & $<.2$ & $<.2$ & $<.2$ \\
\hline & $06-16-92$ & 85 & $<.2$ & $<.2$ & $<.2$ & 15 & $<.2$ & $<.2$ & $<.2$ & $<.2$ & $<.2$ & $<.2$ & $<.2$ \\
\hline MG-1238 & $11-16-90$ & 110 & $<.2$ & $<.2$ & $<.2$ & 2.7 & $<.2$ & $<.2$ & $<.2$ & $<.2$ & $<.2$ & $<.2$ & $<.2$ \\
\hline \multirow[t]{2}{*}{ MG-1239 } & $11-30-90$ & 60 & .4 & $<.2$ & $<.2$ & 25 & $<.2$ & $<.2$ & $<.2$ & $<.2$ & $<.2$ & $<.2$ & $<.2$ \\
\hline & $11-30-90$ & 80 & .5 & $<.2$ & $<.2$ & 14 & $<.2$ & $<.2$ & $<.2$ & $<.2$ & $<.2$ & $<.2$ & $<.2$ \\
\hline \multirow[t]{2}{*}{ MG-1240 } & $11-29-90$ & 90 & $<.2$ & $<.2$ & $<.2$ & $<.2$ & $<.2$ & $<.2$ & $<.2$ & $<.2$ & $<.2$ & $<.2$ & $<.2$ \\
\hline & $11-29-90$ & 60 & $<.2$ & $<.2$ & $<.2$ & $<.2$ & $<.2$ & $<.2$ & $<.2$ & $<.2$ & $<.2$ & $<.2$ & $<.2$ \\
\hline MG-1241 & $12-13-90$ & 110 & $<.2$ & $<.2$ & $<.2$ & $<.2$ & $<.2$ & $<.2$ & $<.2$ & $<.2$ & $<.2$ & $<.2$ & $<.2$ \\
\hline MG-1242 & $12-13-90$ & 90 & $<.2$ & $<.2$ & $<.2$ & $<.2$ & $<.2$ & $<.2$ & $<.2$ & $<.2$ & $<.2$ & $<.2$ & $<.2$ \\
\hline
\end{tabular}


Table 9. Results of chemical analysis for volatile organic compounds--Continued

[All results are total concentrations in micrograms per liter; $<$, less than; --, no data]

\begin{tabular}{|c|c|c|c|c|c|c|c|c|c|c|c|c|c|c|}
\hline $\begin{array}{l}\text { UiS. Geologlcal } \\
\text { Survey } \\
\text { well number }\end{array}$ & Date & $\begin{array}{l}\text { Chlo- } \\
\text { roform }\end{array}$ & $\begin{array}{l}\text { Dlchloro- } \\
\text { bromo- } \\
\text { methane }\end{array}$ & $\begin{array}{l}\text { Dichloro- } \\
\text { difluoro- } \\
\text { methane }\end{array}$ & $\begin{array}{l}\text { 1,1- } \\
\text { Dichloro- } \\
\text { ethane }\end{array}$ & $\begin{array}{c}\text { 1,2- } \\
\text { Dichloro- } \\
\text { ethane }\end{array}$ & $\begin{array}{c}\text { 1,1- } \\
\text { - Dichloro- } \\
\text { ethylene }\end{array}$ & $\begin{array}{l}\text { trans- } \\
1,2- \\
\text { Dichloro- } \\
\text { ethene }\end{array}$ & $\begin{array}{c}\text { 1,2- } \\
\text { Dichloro- } \\
\text { propane }\end{array}$ & $\begin{array}{l}\text { 1,3- } \\
\text { Dlchloro- } \\
\text { propene }\end{array}$ & $\begin{array}{c}\text { cis- } \\
1,3- \\
\text { Dichloro- } \\
\text { propene }\end{array}$ & $\begin{array}{c}\text { trans- } \\
1,3- \\
\text { Dichloro- } \\
\text { propene }\end{array}$ & $\begin{array}{c}\text { Ethyl } \\
\text { benzene }\end{array}$ & $\begin{array}{l}\text { Methyl- } \\
\text { bromide }\end{array}$ \\
\hline \multicolumn{15}{|c|}{ Bucks County } \\
\hline BK -372 & $03-04-91$ & 1.9 & $<0.2$ & $<0.2$ & $<0.2$ & $<0.2$ & $<0.2$ & $<0.2$ & $<0.2$ & $<0.2$ & $<0.2$ & $<0.2$ & $<0.2$ & $<0.2$ \\
\hline BK -693 & $12-10-90$ & .8 & $<.2$ & $<.2$ & $<.2$ & $<.2$ & $<.2$ & $<.2$ & $<.2$ & $<.2$ & $<.2$ & $<.2$ & $<.2$ & $<.2$ \\
\hline BK-948 & $11-29-90$ & $<.2$ & $<.2$ & $<.2$ & $<.2$ & $<.2$ & $<.2$ & $<.2$ & $<.2$ & $<.2$ & $<.2$ & $<.2$ & $<.2$ & $<.2$ \\
\hline \multirow[t]{2}{*}{ BK-949 } & $03-20-91$ & .2 & $<.2$ & $<.2$ & .7 & $<.2$ & .4 & 16 & $<.2$ & $<.2$ & $<.2$ & $<.2$ & $<.2$ & $<.2$ \\
\hline & 03-20-91 & .2 & $<.2$ & $<.2$ & .7 & $<.2$ & .5 & 17 & $<.2$ & $<.2$ & $<.2$ & $<.2$ & $<.2$ & $<.2$ \\
\hline BK-1020 & $04-18-91$ & $<.2$ & $<.2$ & $<.2$ & $<.2$ & $<.2$ & $<.2$ & $<.2$ & $<.2$ & $<.2$ & $<.2$ & $<.2$ & $<.2$ & $<.2$ \\
\hline BK -1058 & $03-20-91$ & .9 & $<.2$ & $<.2$ & $<.2$ & $<.2$ & $<.2$ & $<.2$ & $<.2$ & $<.2$ & $<.2$ & $<.2$ & $<.2$ & $<.2$ \\
\hline BK-1145 & $08-16-91$ & $<.2$ & $<.2$ & $<.2$ & $<.2$ & $<.2$ & $<.2$ & $<.2$ & $<.2$ & $<.2$ & $<.2$ & $<.2$ & $<.2$ & $<.2$ \\
\hline BK-1146 & $07-17-91$ & $<.2$ & $<.2$ & $<.2$ & $<.2$ & $<.2$ & $<.2$ & $<.2$ & $<.2$ & $<.2$ & $<.2$ & $<.2$ & $<.2$ & $<.2$ \\
\hline BK-1831 & $06-20-91$ & $<.2$ & $<.2$ & $<.2$ & $<.2$ & $<.2$ & $<.2$ & $<.2$ & $<.2$ & $<.2$ & $<.2$ & $<.2$ & $<.2$ & $<.2$ \\
\hline BK-1832 & $07-17-91$ & .7 & $<.2$ & $<.2$ & $<.2$ & $<.2$ & $<.2$ & $<.2$ & $<.2$ & $<.2$ & $<.2$ & $<.2$ & $<.2$ & $<.2$ \\
\hline BK-1833 & $06-21-91$ & $<.2$ & $<.2$ & $<.2$ & $<.2$ & $<.2$ & $<.2$ & $<.2$ & $<.2$ & $<.2$ & $<.2$ & $<.2$ & $<.2$ & $<.2$ \\
\hline BK-1834 & $07-17-91$ & $<.2$ & $<.2$ & $<.2$ & $<.2$ & $<.2$ & $<.2$ & $<.2$ & $<.2$ & $<.2$ & $<.2$ & $<.2$ & $<.2$ & $<.2$ \\
\hline BK-1843 & $07-18-91$ & .2 & $<.2$ & $<.2$ & $<.2$ & $<.2$ & $<.2$ & $<.2$ & $<.2$ & $<.2$ & $<.2$ & $<.2$ & $<.2$ & $<.2$ \\
\hline BK-1844 & $07-18-91$ & $<.2$ & $<.2$ & $<.2$ & $<.2$ & $<.2$ & $<.2$ & $<.2$ & $<.2$ & $<.2$ & $<.2$ & $<.2$ & $<.2$ & $<.2$ \\
\hline \multicolumn{15}{|c|}{ Montgomery County } \\
\hline MG-213 & $06-20-91$ & .3 & $<.2$ & $<.2$ & $<.2$ & $<.2$ & $<.2$ & .3 & $<.2$ & $<.2$ & $<.2$ & $<.2$ & $<.2$ & $<.2$ \\
\hline MG-216 & $06-10-91$ & .2 & $<.2$ & $<.2$ & $<.2$ & $<.2$ & $<.2$ & $<.2$ & $<.2$ & $<.2$ & $<.2$ & $<.2$ & $<.2$ & $<.2$ \\
\hline MG-217 & $06-10-91$ & 3.8 & .2 & $<.2$ & $<.2$ & $<.2$ & $<.2$ & .2 & $<.2$ & $<.2$ & $<.2$ & $<.2$ & $<.2$ & $<.2$ \\
\hline \multirow[t]{2}{*}{ MG-218 } & $01-18-91$ & $<.2$ & $<.2$ & .2 & $<.2$ & $<.2$ & $<.2$ & $<.2$ & $<.2$ & $<.2$ & $<.2$ & $<.2$ & $<.2$ & $<.2$ \\
\hline & $06-10-91$ & .2 & $<.2$ & $<.2$ & $<.2$ & $<.2$ & $<.2$ & .4 & $<.2$ & $<.2$ & $<.2$ & $<.2$ & $<.2$ & $<.2$ \\
\hline MG-219 & $06-20-91$ & .3 & $<.2$ & $<.2$ & $<.2$ & $<.2$ & $<.2$ & $<.2$ & $<.2$ & $<.2$ & $<.2$ & $<.2$ & $<.2$ & $<.2$ \\
\hline MG-220 & $11-15-90$ & .2 & $<.2$ & $<.2$ & $<.2$ & $<.2$ & $<.2$ & 1.6 & $<.2$ & $<.2$ & $<.2$ & $<.2$ & $<.2$ & $<.2$ \\
\hline MG-942 & $06-10-91$ & .7 & $<.2$ & $<.2$ & $<.2$ & $<.2$ & $<.2$ & .8 & $<.2$ & $<.2$ & $<.2$ & $<.2$ & $<.2$ & $<.2$ \\
\hline MG-944 & $06-10-91$ & .3 & $<.2$ & $<.2$ & .4 & $<.2$ & .2 & 9.4 & $<.2$ & $<.2$ & $<.2$ & $<.2$ & $<.2$ & $<.2$ \\
\hline MG-945 & 08-16-91 & .4 & $<.2$ & $<.2$ & .2 & $<.2$ & .3 & $<.2$ & $<.2$ & $<.2$ & $<.2$ & $<.2$ & $<.2$ & $<.2$ \\
\hline MG-946 & $04-16-92$ & .3 & $<.2$ & $<.2$ & .2 & $<.2$ & $<.2$ & $<.2$ & $<.2$ & -- & $<.2$ & $<.2$ & $<.2$ & $<.2$ \\
\hline MG-947 & $06-10-91$ & 1.0 & $<.2$ & $<.2$ & .8 & $<.2$ & 6.8 & 33 & $<.2$ & $<.2$ & $<.2$ & $<.2$ & $<.2$ & $<.2$ \\
\hline MG-948 & $08-16-91$ & .3 & .6 & $<.2$ & $<.2$ & $<.2$ & $<.2$ & .4 & $<.2$ & $<.2$ & $<.2$ & $<.2$ & $<.2$ & $<.2$ \\
\hline MG-949 & 08-16-91 & .4 & $<.2$ & $<.2$ & $<.2$ & $<.2$ & $<.2$ & $<.2$ & $<.2$ & $<.2$ & $<.2$ & $<.2$ & $<.2$ & $<.2$ \\
\hline MG-950 & 08-16-91 & $<.2$ & $<.2$ & $<.2$ & $<.2$ & $<.2$ & $<.2$ & $<.2$ & $<.2$ & $<.2$ & $<.2$ & $<.2$ & $<.2$ & $<.2$ \\
\hline \multirow[t]{2}{*}{ MG-951 } & $12-10-90$ & .2 & $<.2$ & $<.2$ & $<.2$ & $<.2$ & $<.2$ & $<.2$ & $<.2$ & $<.2$ & $<.2$ & $<.2$ & $<.2$ & $<.2$ \\
\hline & $12-10-90$ & .3 & $<.2$ & $<.2$ & $<.2$ & $<.2$ & $<.2$ & .2 & $<.2$ & $<.2$ & $<.2$ & $<.2$ & $<.2$ & $<.2$ \\
\hline \multirow[t]{2}{*}{ MG-1115 } & $11-14-90$ & .2 & $<.2$ & $<.2$ & $<.2$ & $<.2$ & $<.2$ & $<.2$ & $<.2$ & $<.2$ & $<.2$ & $<.2$ & $<.2$ & $<.2$ \\
\hline & $11-14-90$ & $<.2$ & $<.2$ & $<.2$ & $<.2$ & $<.2$ & $<.2$ & $<.2$ & $<.2$ & $<.2$ & $<.2$ & $<.2$ & $<.2$ & $<.2$ \\
\hline MG-1235 & $05-17-91$ & 1.9 & $<.2$ & $<.2$ & $<.2$ & $<.2$ & .4 & 13 & $<.2$ & $<.2$ & $<.2$ & $<.2$ & $<.2$ & $<2$ \\
\hline \multirow[t]{4}{*}{ MG-1236 } & $11-16-90$ & $<2.0$ & $<2.0$ & $<2.0$ & $<2.0$ & $<2.0$ & 28 & $<2.0$ & 60 & $<2.0$ & $<2.0$ & $<2.0$ & $<2.0$ & $<2.0$ \\
\hline & $06-05-91$ & .7 & .2 & $<.2$ & .6 & $<.2$ & 8.4 & 43 & $<.2$ & $<.2$ & $<.2$ & $<.2$ & $<.2$ & $<.2$ \\
\hline & $06-16-92$ & .2 & $<.2$ & $<.2$ & .6 & $<.2$ & 9.0 & 5.8 & $<.2$ & $<.2$ & $<.2$ & $<.2$ & $<.2$ & $<.2$ \\
\hline & $06-16-92$ & .6 & $<.2$ & $<.2$ & .5 & $<.2$ & 8.3 & 32 & $<.2$ & $<.2$ & $<.2$ & $<.2$ & $<.2$ & $<.2$ \\
\hline \multirow[t]{3}{*}{ MG-1237 } & $11-15-90$ & 3.1 & $<.2$ & $<.2$ & .5 & $<.2$ & 9.6 & 21 & $<.2$ & $<.2$ & $<.2$ & $<.2$ & $<.2$ & $<.2$ \\
\hline & $11-15-90$ & 3.0 & $<.2$ & $<.2$ & .5 & $<.2$ & 9.8 & 22 & $<.2$ & $<.2$ & $<.2$ & $<.2$ & $<.2$ & $<.2$ \\
\hline & $06-16-92$ & 2.8 & $<.2$ & $<.2$ & .5 & $<.2$ & 12 & 22 & $<.2$ & $<.2$ & $<.2$ & $<.2$ & $<.2$ & $<.2$ \\
\hline MG-1238 & $11-16-90$ & 1.7 & $<.2$ & $<.2$ & 3.0 & .2 & 2.3 & 2.7 & $<.2$ & $<.2$ & $<.2$ & $<.2$ & $<.2$ & $<2$ \\
\hline \multirow[t]{2}{*}{ MG-1239 } & $11-30-90$ & 15 & .2 & $<.2$ & 8.4 & 3.9 & 190 & 69 & $<.2$ & $<.2$ & $<.2$ & $<.2$ & $<.2$ & $<.2$ \\
\hline & $11-30-90$ & 15 & .4 & $<.2$ & 14 & 5.6 & 260 & 29 & $<.2$ & $<.2$ & $<.2$ & $<.2$ & $<.2$ & $<.2$ \\
\hline \multirow[t]{2}{*}{ MG-1240 } & $11-29-90$ & $<.2$ & $<.2$ & $<.2$ & .4 & $<.2$ & .2 & 71 & $<.2$ & $<.2$ & $<.2$ & $<.2$ & $<.2$ & $<.2$ \\
\hline & $11-29-90$ & $<.2$ & $<.2$ & $<.2$ & .3 & $<.2$ & .2 & 72 & $<.2$ & $<.2$ & $<.2$ & $<.2$ & $<.2$ & $<.2$ \\
\hline MG-1241 & $12-13-90$ & .6 & $<.2$ & $<.2$ & .8 & $<.2$ & 1.8 & 1.7 & .3 & $<.2$ & $<.2$ & $<.2$ & $<.2$ & $<.2$ \\
\hline MG-1242 & $12-13-90$ & .2 & $<.2$ & $<.2$ & $<.2$ & $<.2$ & $<.2$ & $<.2$ & $<.2$ & $<.2$ & $<.2$ & $<.2$ & $<.2$ & $<.2$ \\
\hline
\end{tabular}


Table 9. Results of chemical analysis for volatile organic compounds—Continued

[All results are total concentrations in micrograms per liter; <, less than; --, no data]

\begin{tabular}{|c|c|c|c|c|c|c|c|c|c|c|c|c|c|}
\hline $\begin{array}{l}\text { U.S. Geological } \\
\text { Survey } \\
\text { well number }\end{array}$ & Date & $\begin{array}{l}\text { Methyl- } \\
\text { chloride }\end{array}$ & $\begin{array}{l}\text { Methylene } \\
\text { chloride }\end{array}$ & Styrene & $\begin{array}{l}\text { 1,1,2,2- } \\
\text { Tetra- } \\
\text { chloro- } \\
\text { ethane }\end{array}$ & $\begin{array}{l}\text { Tetra- } \\
\text { chloro- } \\
\text { ethylene }\end{array}$ & Toluene & $\begin{array}{l}\text { 1,1,1- } \\
\text { Trichloro- } \\
\text { ethane }\end{array}$ & $\begin{array}{l}\text { 1,1,2,- } \\
\text { Trichloro- } \\
\text { ethane }\end{array}$ & $\begin{array}{c}\text { Tri- } \\
\text { chloro- } \\
\text { ethylene }\end{array}$ & $\begin{array}{c}\text { Trl- } \\
\text { chloro- } \\
\text { fluoro- } \\
\text { methane }\end{array}$ & $\begin{array}{l}\text { VInyl } \\
\text { chloride }\end{array}$ & Xylene \\
\hline \multicolumn{14}{|c|}{ Bucks County } \\
\hline BK-372 & $03-04-91$ & $<0.2$ & $<0.2$ & $<0.2$ & $<0.2$ & 0.4 & $<0.2$ & 1.9 & $<0.2$ & 0.7 & $<0.2$ & $<0.2$ & $<0.2$ \\
\hline BK -693 & $12-10-90$ & $<.2$ & $<.2$ & $<.2$ & $<.2$ & .2 & $<.2$ & $<.2$ & $<.2$ & .7 & $<.2$ & $<.2$ & $<.2$ \\
\hline BK-948 & $11-29-90$ & $<.2$ & $<.2$ & $<.2$ & $<.2$ & $<.2$ & $<.2$ & $<.2$ & $<.2$ & 2.2 & $<.2$ & $<.2$ & $<.2$ \\
\hline \multirow[t]{2}{*}{ BK-949 } & $03-20-91$ & $<.2$ & $<.2$ & $<.2$ & $<.2$ & 160 & $<.2$ & 1.0 & $<.2$ & 12 & .2 & $<.2$ & $<.2$ \\
\hline & $03-20-91$ & $<.2$ & $<.2$ & $<.2$ & $<.2$ & 170 & $<.2$ & 1.1 & $<.2$ & 13 & .2 & $<.2$ & $<.2$ \\
\hline BK-1020 & $04-18-91$ & $<.2$ & $<.2$ & $<.2$ & $<.2$ & $<.2$ & $<.2$ & $<.2$ & $<.2$ & $<.2$ & $<.2$ & $<.2$ & $<.2$ \\
\hline BK-1058 & $03-20-91$ & $<.2$ & $<.2$ & $<.2$ & $<.2$ & .6 & $<.2$ & $<.2$ & $<.2$ & $<.2$ & $<.2$ & $<.2$ & $<.2$ \\
\hline BK-1145 & $08-16-91$ & $<.2$ & $<.2$ & $<.2$ & $<.2$ & $<.2$ & $<.2$ & $<.2$ & $<.2$ & $<.2$ & $<.2$ & $<.2$ & $<.2$ \\
\hline BK-1146 & $07-17-91$ & $<.2$ & $<.2$ & $<.2$ & $<.2$ & $<.2$ & $<.2$ & $<.2$ & $<.2$ & $<.2$ & $<.2$ & $<.2$ & $<.2$ \\
\hline BK-1831 & $06-20-91$ & $<.2$ & $<.2$ & $<.2$ & $<.2$ & 1.6 & $<.2$ & $<.2$ & $<.2$ & .7 & $<.2$ & $<.2$ & $<.2$ \\
\hline BK-1832 & $07-17-91$ & $<.2$ & $<.2$ & $<.2$ & $<.2$ & $<.2$ & $<.2$ & $<.2$ & $<.2$ & $<.2$ & $<.2$ & $<.2$ & $<.2$ \\
\hline BK-1833 & $06-21-91$ & $<.2$ & $<.2$ & $<.2$ & $<.2$ & .2 & $<.2$ & $<.2$ & $<.2$ & $<.2$ & $<.2$ & $<.2$ & $<.2$ \\
\hline BK-1834 & $07-17-91$ & $<.2$ & $<.2$ & $<.2$ & $<.2$ & $<.2$ & $<.2$ & $<.2$ & $<.2$ & $<.2$ & $<.2$ & $<.2$ & $<.2$ \\
\hline BK-1843 & $07-18-91$ & $<.2$ & $<.2$ & $<.2$ & $<.2$ & $<.2$ & $<.2$ & $<.2$ & $<.2$ & $<.2$ & $<.2$ & $<.2$ & $<.2$ \\
\hline BK-1844 & 07-18-91 & $<.2$ & $<.2$ & $<.2$ & $<.2$ & $<.2$ & $<.2$ & .2 & $<.2$ & $<.2$ & $<.2$ & $<.2$ & $<.2$ \\
\hline \multicolumn{14}{|c|}{ Montgomery County } \\
\hline MG-213 & $06-20-91$ & $<.2$ & $<.2$ & $<.2$ & $<.2$ & .3 & $<.2$ & .2 & $<.2$ & 73 & $<.2$ & $<.2$ & $<.2$ \\
\hline MG-216 & $06-10-91$ & $<.2$ & $<.2$ & $<.2$ & $<.2$ & .2 & $<.2$ & .2 & $<.2$ & .3 & $<.2$ & $<.2$ & $<.2$ \\
\hline MG-217 & $06-10-91$ & $<.2$ & $<.2$ & $<.2$ & $<.2$ & .4 & .2 & .2 & $<.2$ & 7.4 & $<.2$ & $<.2$ & $<.2$ \\
\hline \multirow[t]{2}{*}{ MG-218 } & $01-18-91$ & $<.2$ & $<.2$ & $<.2$ & $<.2$ & .9 & $<.2$ & .2 & $<.2$ & .2 & $<.2$ & $<.2$ & $<.2$ \\
\hline & $06-10-91$ & $<.2$ & $<.2$ & $<.2$ & $<.2$ & .6 & $<.2$ & .4 & $<.2$ & 1.1 & $<.2$ & $<.2$ & $<.2$ \\
\hline MG-219 & $06-20-91$ & $<.2$ & $<.2$ & $<.2$ & $<.2$ & $<.2$ & $<.2$ & .5 & $<.2$ & $<.2$ & $<.2$ & $<.2$ & $<.2$ \\
\hline MG-220 & $11-15-90$ & $<.2$ & $<.2$ & $<.2$ & $<.2$ & .4 & $<.3$ & .3 & $<.2$ & 33 & $<.2$ & $<.2$ & $<.2$ \\
\hline MG-942 & $06-10-91$ & $<.2$ & $<.2$ & $<.2$ & $<.2$ & $<.2$ & .4 & $<.2$ & $<.2$ & 7.6 & $<.2$ & $<.2$ & $<.2$ \\
\hline MG-944 & $06-10-91$ & $<.2$ & $<.2$ & $<.2$ & $<.2$ & .3 & $<.2$ & .6 & $<.2$ & 340 & $<.2$ & .3 & $<.2$ \\
\hline MG-945 & $08-16-91$ & $<.2$ & $<.2$ & $<.2$ & $<.2$ & .2 & $<.2$ & 2.3 & $<.2$ & .2 & $<.2$ & $<.2$ & $<.2$ \\
\hline MG-946 & 04-16-92 & $<.2$ & $<.2$ & $<.2$ & $<.2$ & 2.9 & $<.2$ & .3 & $<.2$ & 12 & $<.2$ & $<.2$ & $<.2$ \\
\hline MG-947 & 06-10-91 & $<.2$ & $<.2$ & $<.2$ & $<.2$ & 5.3 & .2 & 42 & $<.2$ & 270 & .3 & $<.2$ & $<.2$ \\
\hline MG-948 & $08-16-91$ & $<.2$ & $<.2$ & $<.2$ & $<.2$ & 3.1 & $<.2$ & $<.2$ & $<.2$ & .4 & $<.2$ & $<.2$ & $<.2$ \\
\hline MG-949 & 08-16-91 & $<.2$ & $<.2$ & $<.2$ & $<.2$ & 1.1 & $<.2$ & .2 & $<.2$ & $<.2$ & $<.2$ & $<.2$ & $<.2$ \\
\hline MG-950 & $08-16-91$ & $<.2$ & $<.2$ & $<.2$ & $<.2$ & $<.2$ & $<.2$ & .2 & $<.2$ & .3 & $<.2$ & $<.2$ & $<.2$ \\
\hline \multirow[t]{2}{*}{ MG-951 } & $12-10-90$ & $<.2$ & $<.2$ & $<.2$ & $<.2$ & $<.2$ & $<.2$ & $<.2$ & $<.2$ & 9.2 & $<.2$ & $<.2$ & $<.2$ \\
\hline & $12-10-90$ & $<.2$ & $<.2$ & $<.2$ & $<.2$ & $<.2$ & $<.2$ & .2 & $<.2$ & 13 & $<.2$ & $<.2$ & $<.2$ \\
\hline \multirow[t]{2}{*}{ MG-1115 } & $11-14-90$ & $<.2$ & $<.2$ & $<.2$ & $<.2$ & $<.2$ & $<.4$ & .3 & $<.2$ & $<.2$ & $<.2$ & $<.2$ & $<.2$ \\
\hline & $11-14-90$ & $<.2$ & $<.2$ & $<.2$ & $<.2$ & $<.2$ & $<.4$ & .3 & $<.2$ & $<2$ & $<.2$ & $<.2$ & $<.2$ \\
\hline MG-1235 & $05-17-91$ & $<.2$ & $<.2$ & $<.2$ & $<.2$ & .7 & .2 & .3 & .2 & 1,400 & $<.2$ & $<.2$ & $<.2$ \\
\hline \multirow[t]{4}{*}{ MG-1236 } & $11-16-90$ & $<2.0$ & $<2.0$ & $<2.0$ & $<2.0$ & 2.6 & $<2.0$ & $<2.0$ & $<2.0$ & 5,500 & $<2.0$ & $<2.0$ & $<2.0$ \\
\hline & $06-05-91$ & $<.2$ & $<.2$ & $<.2$ & $<.2$ & 1.8 & .2 & 15 & .4 & 3,900 & $<.2$ & .2 & $<.2$ \\
\hline & $06-16-92$ & $<.2$ & .2 & $<.2$ & $<.2$ & $<.2$ & $<.2$ & 17 & $<.2$ & 280 & $<.2$ & $<.2$ & $<.2$ \\
\hline & 06-16-92 & $<.2$ & $<.2$ & $<.2$ & $<.2$ & 1.7 & $<.2$ & 9.5 & .4 & 3,400 & $<.2$ & $<.2$ & $<.2$ \\
\hline \multirow[t]{3}{*}{ MG-1237 } & $11-15-90$ & $<.2$ & $<.2$ & $<.2$ & $<.2$ & .6 & $<.2$ & 11 & .3 & 570 & $<.2$ & $<.2$ & $<.2$ \\
\hline & $11-15-90$ & $<.2$ & $<.2$ & $<.2$ & $<.2$ & .6 & $<.2$ & 11 & .3 & 660 & $<.2$ & $<.2$ & $<.2$ \\
\hline & 06-16-92 & $<.2$ & $<.2$ & $<.2$ & $<.2$ & .8 & $<.2$ & 6.5 & .3 & 670 & $<.2$ & $<.2$ & $<.2$ \\
\hline MG-1238 & $11-16-90$ & $<.2$ & $<.2$ & $<.2$ & $<.2$ & 10 & $<.2$ & 34 & $<.2$ & 480 & $<.2$ & $<.2$ & $<.2$ \\
\hline \multirow[t]{2}{*}{ MG-1239 } & $11-30-90$ & $<.2$ & .3 & $<.2$ & $<.2$ & 44 & $<.2$ & 1,000 & $<.2$ & 4,900 & $<.2$ & .8 & $<.2$ \\
\hline & $11-30-90$ & $<.2$ & .4 & $<.2$ & $<.2$ & 57 & $<.2$ & 1,400 & $<.2$ & 5,800 & $<.2$ & 1.4 & $<.2$ \\
\hline \multirow[t]{2}{*}{ MG-1240 } & $11-29-90$ & $<.2$ & $<.2$ & $<.2$ & $<.2$ & 31 & $<.2$ & .2 & $<.2$ & 110 & $<.2$ & $<.2$ & $<.2$ \\
\hline & $11-29-90$ & $<.2$ & $<.2$ & $<.2$ & $<.2$ & 25 & $<.2$ & $<.2$ & $<.2$ & 110 & $<.2$ & $<.2$ & $<.2$ \\
\hline MG-1241 & $12-13-90$ & $<.2$ & $<.2$ & $<.2$ & $<.2$ & 1.3 & $<.2$ & 2.7 & $<.2$ & 12 & .9 & $<.2$ & $<.2$ \\
\hline MG-1242 & $12-13-90$ & $<.2$ & $<.2$ & $<.2$ & $<.2$ & $<.2$ & $<.2$ & $<.2$ & $<.2$ & 1.2 & $<.2$ & $<.2$ & $<.2$ \\
\hline
\end{tabular}




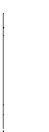

I

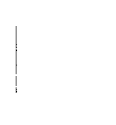

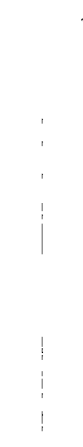

r 